$1-1-1957$

\title{
Employment and underemployment of rural people in the Upper Monongahela Valley, West Virginia
}

William H. Metzler

Ward F. Porter

Follow this and additional works at: https://researchrepository.wvu.edu/ wv_agricultural_and_forestry_experiment_station_bulletins

\section{Digital Commons Citation}

Metzler, William H. and Porter, Ward F., "Employment and underemployment of rural people in the Upper Monongahela Valley, West Virginia" (1957). West Virginia Agricultural and Forestry Experiment Station Bulletins. 404.

https://researchrepository.wvu.edu/wv_agricultural_and_forestry_experiment_station_bulletins/389 @ WVU. It has been accepted for inclusion in West Virginia Agricultural and Forestry Experiment Station Bulletins by an authorized administrator of The Research Repository @ WVU. For more information, please contact ian.harmon@mail.wvu.edu. 


\section{UPLOYMENT and UNDEREMPLOYMENT}

of RURAL PEOPLE in the UPPER

ONONGAHELA VALLEY, WEST VIRGINIA

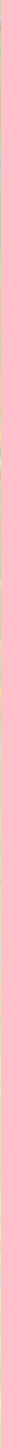




\section{ACKNOWLEDGMENTS}

The writers gratefully acknowledge the contributions of many indivicluals to this report. Among those to whom they are particularly indebted are fellow members of the project committee: W. IV. Armentrout of the West Virginia Agricultural Experiment Station, and O. J. Scoville, Joe R. Motheral, R. B. Glasgow, and J. V. McElveen of the Agricultural Research Service, U. S. Department of Agriculture. These individuals, together with James H. Clarke, Norman Nybroten, and George E. Toben of the West Virginia Agricultural Experiment Station, have contributed much in the way of advice and constructive criticism throughout the survey.

Credit is also due Leo Fishman of the College of Commerce, West Virginia University, and C. J. Parsons and Brumback Stephens of the IVest Virginia Department of Employment Security, who provided valuable information on the economic situation in the Upper Monongahela Valley and the State as a whole.

For statistical advice and services, the writers are indebted to Mrs. Justine Foglesong of the West Virginia Agricultural Experiment Station. Also acknowledged are the services of A. J. Ludwig, formerly of West Virginia University, who supervised machine tabulations, and those of Earl Houseman of the U.S. Department of Agriculture, who set up the sample design.

West Virginia University

Agricultural Experinient Station

College of Agriculture, Forestry, and Hone Economics

H. R. V ARNEY, DIRECTOR

MORGANTOWN 


\title{
Employment and Underemployment Of Rural People In
}

The Upper Monongahela Valley,

\section{West Virginia}

\author{
By \\ William H. Metzler \\ and \\ Ward F. Porter
}

WEST VIRGINIA UNIVERSITY AGRICULTURAL

EXPERIMENT STATION

Morgantown

In Cooperation with

Agricultural Research Service

United States Department of Agriculture

Production Economics Rescarch Branch 



\section{Contents}

SUMMARY

INTRODUCTION

ECONOMIC BACKGROUNDS ?

THE UPPER MONONGAHELA VALLEY

PEOPLE AND FARMS IN THE VALLEY ?

IIOUSEHOLDS AND WORKERS IN THE SAMPLE GROUP _.. 12

HousEHOLd SIZE

AGE

Edcational Attainient …_...

Vocational Training

LeVEL OF LIVING _..........

Comparison with Other SURveys $\quad 19$

ACTIVITIES AND OCCUPATIONS OF OPEN-COUNTRY

PEOPLE IN THE VALLEY $\quad 19$

Household Status axd Chief Activity .......... 2]

TYPE OF EMPLOYMENT _._. 22

EMPLOYMENT AND UNIDEREMPLOYMENT OF WORKERS

IN THE VALLEY ... ............

Method of Estmating EMPLOYMENT aNi) UNderexployMENT

Total Days Wonked Pen Person - 27

LeNgth of Employment as Related to Trpe of (Wokk and TYPE OF WORKER

Employinent on the Hoine Farm 32

FARMI-WAGE WORK

Nox FarM EMPloYNeNT

INCOMES OF HOUSEHOLDS AND OF WORKERS IN THE

VALLEY

INDITIDUAL EARNINGS

WORK EXPERIENCE, 1946-1954

YOUTH WHO HAVE LEFT HONE

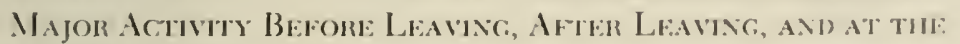

TrMe of TIF SUnVeY

Metiod of Finding, Out Alsout Furst Jols

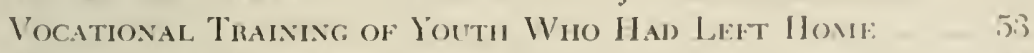

Whane THEX AR: Now 
WORK AWAY FROM HOME 56

WORKERS WHO HAD RETURNED HOME 57

AVAILABILITY FOR EMPLOYMENT _

Work Preferexces _a 60

UNeNPLOYMLNT CoMpensation $\quad 60$

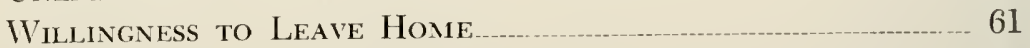

WILLINGNeSS To Move FAMIILY

EMPLOYMENT OF PERSONS AVAILABLE FOR WORK _ _ 62

COMPARISON IVITH OTHER SURVEYS 63

CONCLUSION _- 64

APPENDIX 67

CLASSIFICATION AND TERMINOLOGY 67 


\section{Summary}

CONTINUED slump in coal-mining employment has brought
attention to the problem of inadequate work opportunities for
rural people in coal-mining areas of West Virginia. These areas ordinarily have limited agricultural resources; hence occupational adjustments largely will have to be along nonfarm lines.

A field study was made of 875 households in the open-country area of the Upper Monongahela Valley in July, 1954. The Upper Monongahela Valley was chosen as being roughly typical of the State as a whole.

Although one-third of the households interviewed were located on farms. agriculture was a supplemental rather than a primary source of income for most of them. Only 5 percent of the households in the area depencled on agriculture alone.

Forty percent of the households in the area were those of workers in the mines, factories, stores, and other nonfarm places of employment who relied solely on nonfarm work as a means of support.

Fourteen percent of the households relied for their support solely on nonwork sources of income; i.e., royalties, rents, social security, retirement funds, public assistance.

The remaining 41 percent had income from several of these sources. Most frequently, nonfarm work was the major source, with farming or nonwork income as supplementary.

Of the 2.287 persons in the sample households who were 14 years old or over, 59 pereent had done some work during the 12 months preceding the survey. One-third of them had worked as much as 100 days.

Average length of employment for all persons who worked churing the year was 154 days-185 days for males and 92 for females. Workers whose main cmployment was in agriculture worked for an average of $6: 3$ days. whereas those whose main employment was in nonfarm work were employed for an average of 201 days. This difference is partially due to the fact that two-thirds of the nonfarm workers were males between 24 and 64 years of age, whereas two-thircls of the farm workers were women and youths. Yet underemployment was also eommon among adult male workers on farms.

Evidence of underemployment among open-eountry people include the following: 
(1) An unusually high proportion of nonworkers.

$\begin{array}{cc}\begin{array}{c}\text { Percentage of nonworkers } \\ \text { Upper }\end{array} & \\ \text { Monongahela } & \text { United } \\ \text { Valley } & \text { States } \\ 41 & 36 \\ 18 & 14 \\ 64 & 57\end{array}$

Among all persons 14 years old or over Among males 14 years old and over Among females 14 years old and over

(2) Short-term or no employment among women and youth. Only 11 percent of the women worked as long as 100 dars cluring the previous year, yet 28 percent of them were neither housewives nor in school.

Only 3.5 percent of the sons 14 to 24 years old worked as long as 100 days, yet 53 percent of them were not in school.

(3) Inadequate employment in agriculture.

Males 25 to 64 years old, who worked on the home farm only, worked for an average of 130 days during the previous 12 months.

(4) Inadequate employment among service workers.

Females 25 to 64 years old employed in service work were employed for an average of 93 days during the preceding year.

(5) Some underemployment in coal mining.

Males 25 to 64 years old employed in coal mining worked for an average of 177 days during the preceding year.

The foregoing selected data point toward age, sex, and occupational groups in the Valley which were especially subject to underemployment.

Of the total income of households in the Valley, 80 percent came from nonfarm employment, 14 percent from nonwork sources, and 6 percent from farm operation or farm wages.

Average income of open-country households in the Valley was $\$ 2,675$. Approximately one-fourth of these households had incomes of less than $\$ 1,000$; one-fourth had incomes of over $\$ 3,000$.

Average eamings per worker who engaged in each type of work may be summarized as follows:

$\begin{array}{lcc} & \text { For the year } & \text { Per day worked } \\ \text { Worked on home farm } & \$ 132 & \$ 2.25 \\ \text { Farm-wage work } & 259 & 4.21 \\ \text { Nonfarm work } & 2,206 & 11.85\end{array}$

These averages again are affected by the high proportion of women and children engaged in farm work.

A total of 401 youths had left the 875 survey homes during the previous $S$ years -197 males and 204 females. Half of the young women went into housekeeping when they left home. Most of the remainder 
went into nonfarm work. More than one-third of the young men went into the armed forces. Over one-half went into nonfarm work. Only three became farm operators and two became hired farm workers. Sixty percent of the youth left their home counties; 37 percent left the State. Sixty-nine members of these households (mostly youth) had returned home during the previous year. Half of these stated that they returned because their work gave out.

One hundred and three persons were working away from home at the time of the survey but were still reported as members of the household. Usually they returned home each weekend or at less frequent intervals.

A majority of the nonfarm workers had more than 8 years experience in nonfarm work. New entrants into nonfarm employment were most numerous in the periods 1946-1947 and 1952-1953.

Sixteen percent of the workers 14 years old and over were reported as available for employment. More than 40 percent of these people had done some work during the survey week but were still interested in other employment. Approximately 90 percent of the persons available for employment preferred nonfarm work. Two-thirds of those preferring nonfarm work were willing to leave home to take a job and three-fourths of those who were heads of households were willing to move their families. Only 3 out of 37 workers interested in doing farm work were willing to) leave home. 
Digitized by the Internet Archive in 2010 with funding from

Lyrasis Members and Sloan Foundation 


\section{Employment and Underemployment Of Rural People in the Upper Monongahela Valley, West Virginia}

William H. Metzler and Ward F. Porter*

\section{Introduction}

THIS is the second of a series of publications which deal with the employment problem of rural people in the Upper Monongahela Valley of West Virginia. The first was a report on rural people in the Valley who were available for employment. ${ }^{1}$ Approximately 16 percent of the people of working age in the Valley were reported as being in this group, and more than 90 percent of them desired nonfarm employment. The present report describes the working population in the rural areas of the Valley and examines the extent to which underemployment exists among them. The third report will deal with the potentialities for more complete employment of these people through expansion and improvement of their farming operations.

All three reports are based on data obtained in field intervicws of families living in the open country area of the Valley. A randomized sample of the families in the area was selected for interview. (See $A_{p}$ )pendix for Sampling . Method.) All families in the sample were asked to give detailed data in regard to faming operations and work performerl off the farm during the previous 12 months. These data provided the basis for calculating the number of days of work for each person in each household.

The survey was made during the slump in coal-mining employ ment which became acute in the early part of 19.54 . The demand for conal hat been dropping for several years and mine employees were erachually shifting to other lines of work. In 195.t, however, displaced workers were not able to find other employment, and many who hacl obtained jolss in other industrial areas hard been laid off and were returnines en West Virginia.

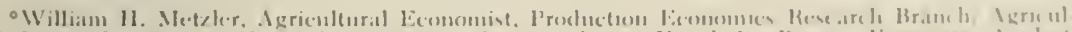

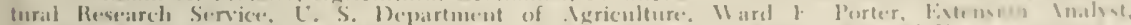

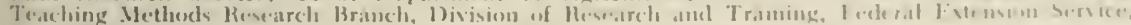
U. S. Department of Agrieulture.

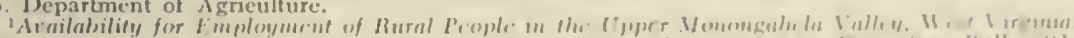

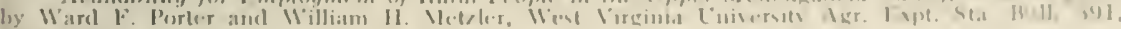
Jine, 1956 . 
Since that time there has been some recovery in the coal industry, but there has been no corresponding increase in employment. Increased production has been achieved through greater use of mechanized equipment. The trend is expected to be in the direction of even more mechanization; hence there is need for some major occupational readjustments among the working population.

Occupational readjustment might conceivably come through (1) expansion of farming operations, (2) movement of workers out of the area to more thriving industrial areas, (3) movement of industry into the area or development of new industries in order to take advantage of the surplus labor supply, or (4) some combination of these methods involving more intensive utilization of both farm and nonfarm resources.

The development of any readjustment program would be aided by an accurate hnowledge of the characteristics of the people involved, their age and sex composition, educational and occupational background, the extent to which they are unemployed or underemployed, and their availability for other kinds of employment. It would also be aided by accurate data concerning the agriculture of the area, and the extent to which underemployment might be taken care of by an expansion of agricultural operations. In addition, an inventory of the undeveloped industrial and commercial resources of the area should reveal potentials for new lines of activity:

The main objective of the present report is to provide information in regard to the population of working age-characteristics, occupations, and employment. Only incidental attention will be given to the physical resources of the area.

\section{Economic Backgrounds}

Survey operations were limited to the Upper Monongahela Valley, as it was felt that this area was typical of economic and employment conditions in the State as a whole. A detailed comparison of the economic situation in the State and in the Valley was made in the first report in this series." The major items in this comparison are shown in Table 1 and will not be repeated here. A few of the highlights of the economic situation can be listed as follows:

Pressure of population on the economic resources of the State at their present level of development is great. Farming is so limited by rough topography, dense coverage of timber, and soil conditions that the residents depend largely on nonfarm employment for a livelihood.

-1hid, pp. 1-16. 
Table 1. Comparative Data on Rurality of Popllation, Indestre Classificatiox of IVorkers, and Class of Farys, Upper Moxoygahela Valley axd State of West Virginia, 1950.

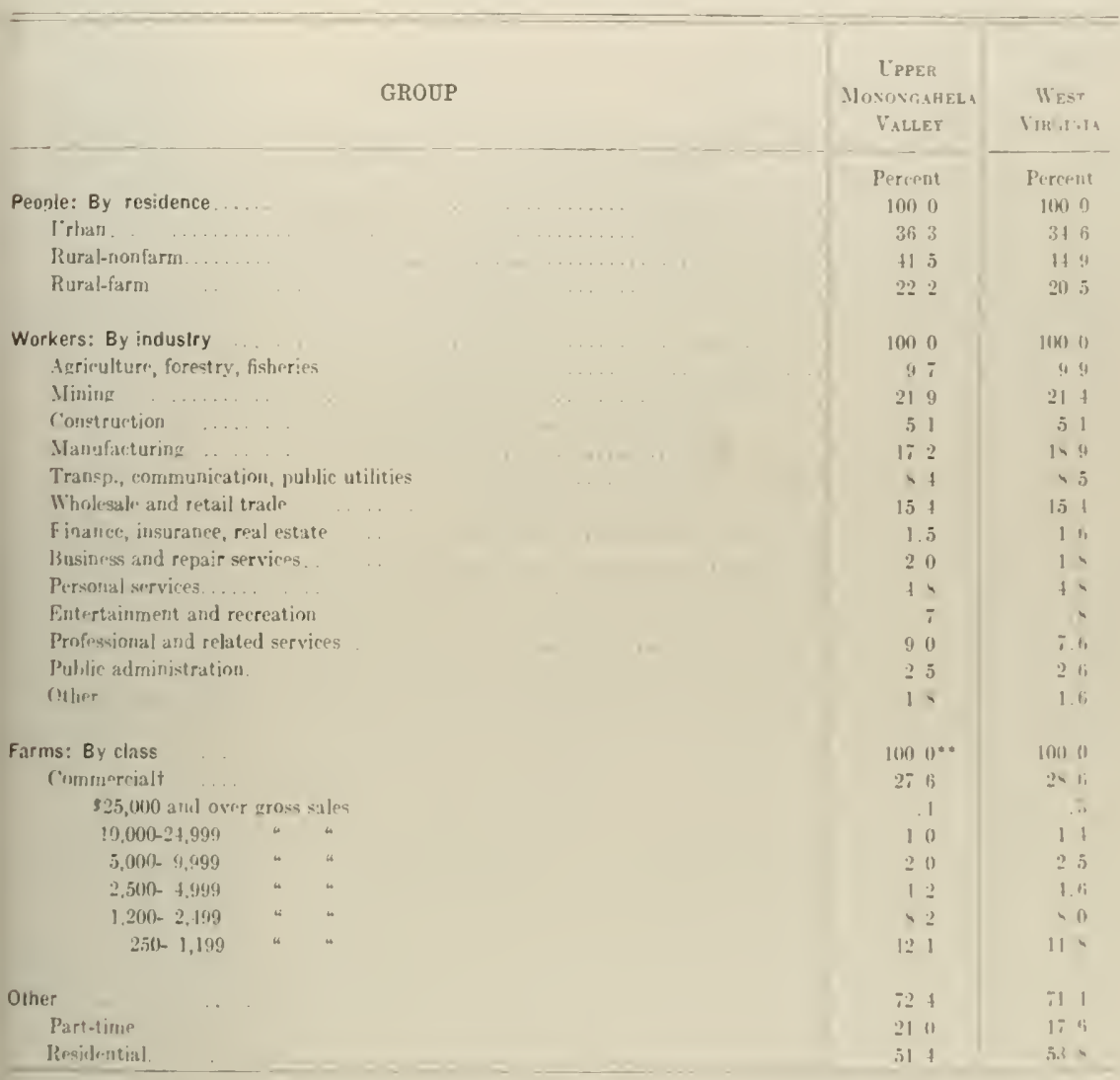

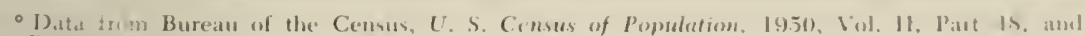
U. S. Cinstes of Agriculture, 1950, Vol. I.

o prercentages based on mumber of farms and farm mperators.

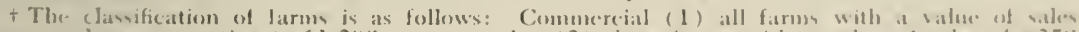

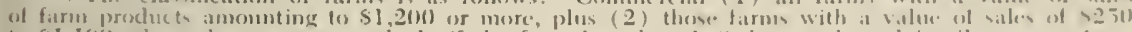

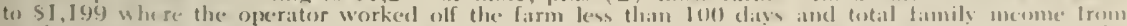

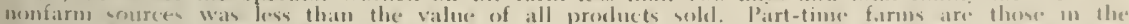

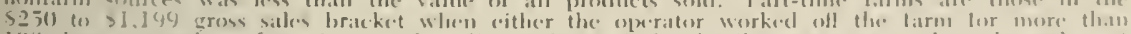

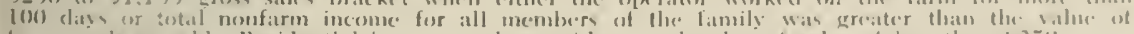

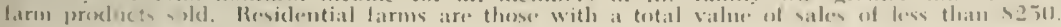

Nonfarm employment in West Virginia has been on the clecline fen

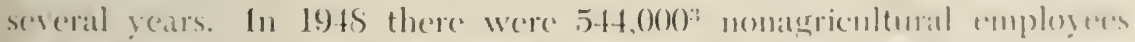

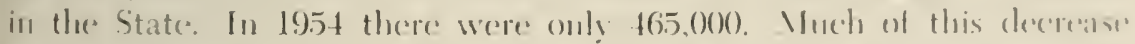
was associated with a decline in emplorment in the bituminmes conal

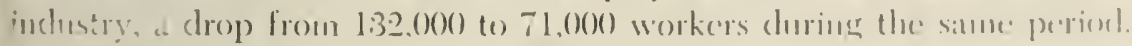

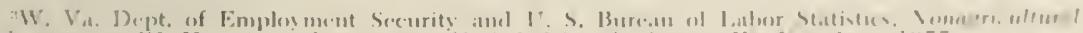

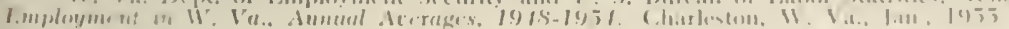


Between April, 1950, and July, 1954, West Virginia had a loss in population of 59.000 persons, or 2.9 percent. ${ }^{4}$ This is only a partial readjustment to reduced employment opportunities. During 19.5 4 , however, there was a return of workers to the State as employment was curtailed in other States.

The future of employment in the bituminous coal industry in the State is difficult to forecast. Substitution of petroleum and natural gas for fuel and power and of machinery for hand labor in the mines may be expected to continue. On the other hand, the aluminum and atomic power industries are creating new demands for coal and may help increase the market for it. This will not necessarily create an increase in employment. Competition from atomic sources of power probably is several decades away and its impact is not now predictable.

\section{The Upper Monongahela Valley}

The Upper Monongahela Valley comprises 10 counties immediately south of the Pennsylvania border: Monongalia, Preston, Marion, Harrison, Taylor, Barbour, Tucker, Lewis, Upshur, and Randolph. Its land area is 4,444 square miles, almost equivalent to that of Comnecticut. In spite of its rough terrain the Valley is densely populated. Census figures show a population of 368,654 in 1950 , an average density of $\$ 2.9$ persons per square mile. ${ }^{5}$

The topography of most of the area varies from rough to hilly and mountainous. Topographic engineers classify it as a "ridges and valleys" area. Valley areas between the mountains are of limited size but have been cleared for farming. Cultivated acreages frequently extend up hillsides with very steep slopes and create problems of erosion. The steeper and more mountainous areas are still covered by timber, and sawmilling is an important industry. In 1950, 58 percent of the land area in the Valley was in farms, but only 9 percent was in harvested crops. By 1954 only 52 percent of the land was in farms and only 8 percent was harvested cropland. ${ }^{6}$

The number of farms in the Valley decreased from 16,96.5 in 1950 to 13,957 in 1954. Average size remained about the same, about 97 acres. Most of the acreage was not farmed intensively; in 1954 only 15 percent of the farm land was classificd as harvested cropland, an average of only 16 acres per farm. Total value of sales of farm products was $\$ 14,349,458$ in 1949, an average of $\$ \$ 46$ per farm.

'Bureau of the Census, Current Population Reports, Series P-25, No. 104, Oct. 25, 1954.

${ }^{5} \mathrm{U}$. S. Bureau of the Census, Population, Vol. I, 1950.

U. S. Bureau of the Census, 1954 Census of Agriculture. Preliminary release on West Virginia. Census data for both 1950 and 1954 are used in this report. The 1950 census data cover population, occupations, and agrienlture, as well as employment. In 19.5.4, data are availibie only for agriculture, manufacturing, and employment. 


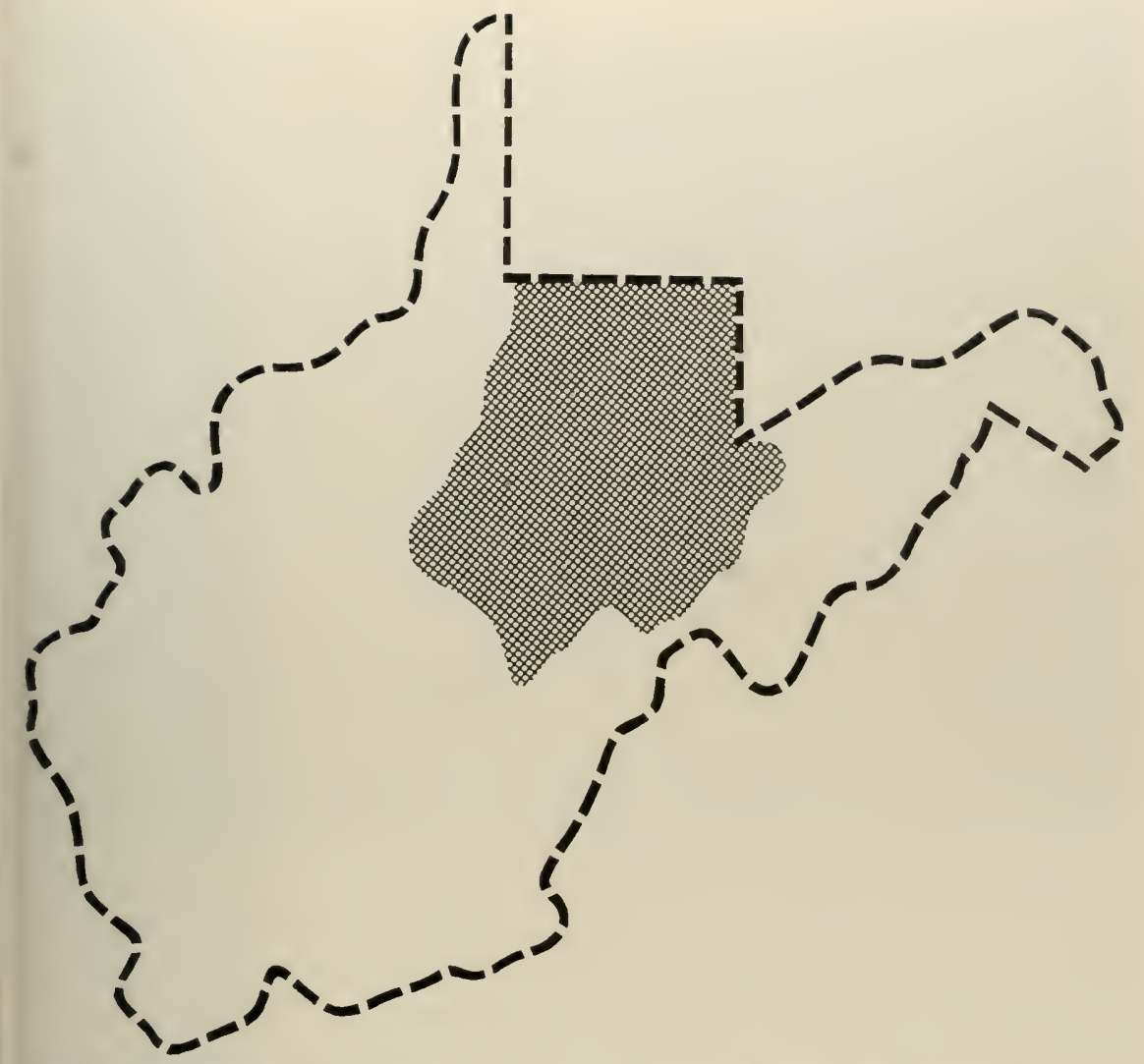

FIGURE 1. Economic conditions in the Valley (shaded area) are generally typical of those in the State as a whale.

The value of the major types of farm produce sold in 1953 was as follows:

Livestock

Dairy products

Poultry and poultry products

$$
\begin{array}{r}
\$ 5,379,055 \\
3,667,065 \\
2,165,514
\end{array}
$$

Is to type of farm, approximately 10 pereent were classified in the 19.54 Census of Agriculture as dairy farms, and 1,3 percent as lisestock farms. Seventy-one percent were classed as miscellaneons and molissifiable. These were largely the part-time and residentiul firms that miners and other nonfarm workers operated in the ir spate time.

According to the 19.54 Census, only S.2 pereent of the firm in the Valley had gross sales of more than $\$ 2.5(0)$. Anothere perernt had grom sales of between $\$ 1.200$ and $\$ 2.50()$. Approvinated! hall the farme in 
the Valley had gross sales of less than \$250. Most of the latter were simply supplementary sources of income to workers or to retirees whose major support came from other sources.

The agricultural base for support of the population therefore is very meager, and recent trends have been in the direction of even less intensive farming. The prospects for competitive commercial agriculture and live-at-home farming, however, are likely to differ. The ability to compete commercially is quite limited, but this limitation may not apply strictly to live-at-home efforts.

Manufacturing is a much more important source of income to the Valley. In 1954 there were 444 manufacturing plants in the Valley which employed about 18,000 workers. The total value added by manufacture in these plants was close to $\$ 120,000,000 .^{\top}$

Among the more important industries in the Valley are sawmilling, and the stone, clay, and glass industries. Recently the chemical industry has come into the area and has added to local payrolls. Although industrial employment has been increasing slowly, it declined briefly during the slump in coal mining. ${ }^{8}$ In spite of the hilly terrain, railroad and highway transportation to the area is good. It is also favorably located for fuel, power, and manpower resources, so there are good potentialities for further industrial development.

The chief source of income for the Valley has been the mining of bituminous coal. There are a few large mining operations in the area but most of the mines are small. Some are small strip mines which use little labor and operate only on an irregular basis. Total employment in the mines in the Valley in April, 1950, was 25,513 persons.

The bituminous coal industry in West Virginia reached its peak in 1947 , with a total production of $173,654,000$ tons. By 1954 production was down to $116,000,000$ tons. ${ }^{9}$ Employment has dropped much more rapidly than production and by 1955 was down to half the 1948 figure. Recent employment figures for West Virginia and the major industrial centers in the sample area are as follows: ${ }^{10}$

¿U. S. Bureau of the Census, Census of Manufactures, 1954, preliminary report on West Virginia. Employment data for the major industrial centers in the V'alley-Morgantown, Fairmont, and Clarkshurg-are available only for the last several years. They indicate that the manufacturing
employment in those centers was as follows: April 1953, 15,290; April 1954, 14,210; April 1955, 15,020. Labor Market Digest, Clarksburg, Fairmont, and Morgantown, Labor Market Areas, West Virginia State Employment Service, Charleston, W. Va.

"The status of the bituminous coal industry in the United States in 1954 has been summarized as follows: At the turn of the century coal provided 90 percent of the nation's energy supply; today, it supplies around 30 percent. Some 2,400 bituminous coal mines have closed in the last 3 years. The price of coal is below the 1948 level yet wages and other costs have increased. A substantial part of the coal industry is operating at a loss. See "Coal's Problem," Nations Business, November, 1954; "Coal in Trouble" by Martin Parkman, Editorial Research Reports, November, 1954. For the IVest Virginia situation, see statements of Leo Fishman, Professor of Economics and Finance, Vest Virginia University, before the Joint Committee on the Economic Report January 27, 1955. Also, Proceedings on the Commcrcial and Economic Health of the Bituminous Coal Industry. WVest Virginia University College of Commerce, Bulletin Series 54, No. 7-1, November, 1953.

"IIIa from West Virginia Emploument Trends and Labor Market Digest, Clarkshurg, Fairmont, and Morgantown Lahor Market Arcas, published monthly. West Virginia State Employment Service, Charleston, West Virginia. 


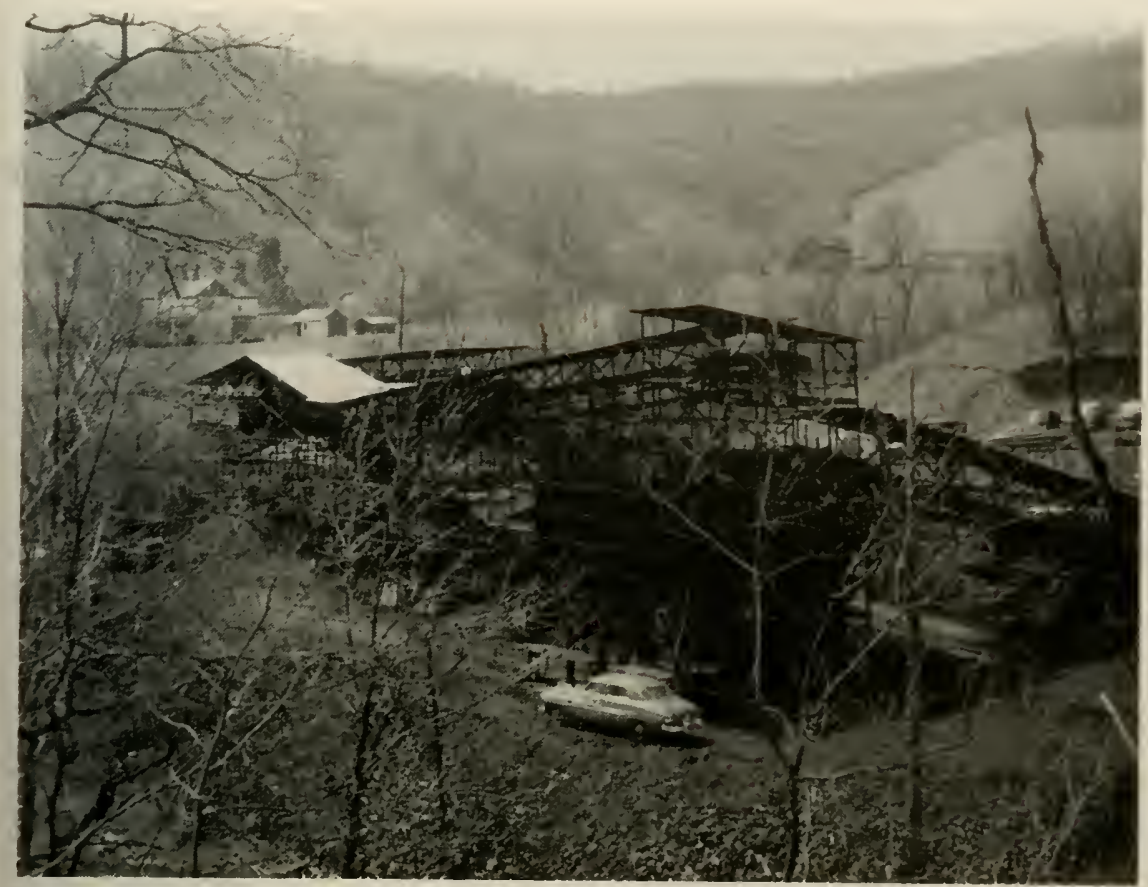

FIGURE 2. Mining and agriculture exist side by side in the open-country areas of West Virginio.

COAL MINING EMPLOYMENT April 1952 April 1953 April 1954 April 1955

$\begin{array}{lrrrr}\text { West Virginia } & 114,900 & 92,100 & 70,700 & 67,200 \\ \text { Morgantown area } & 5,450 & 4,520 & 3,050 & 2,810 \\ \text { Fairmont area } & 6,460 & 5,410 & 4,630 & 3.97() \\ \text { Clarkshurg area } & 0 & 2,90() & 2,400 & 2.25()\end{array}$

Data not available.

Employment opportmities in the area have been shrinking more rapidly than the population. Increases in manufacturing emplorment have been inadequate to offset the declines in mining and agriculture. Ontmigration as a solution to the situation is limited by the strones attachment of the people in the Valley to their home emviromment. Hence al surplus working population may exist there for some time. Me'inwhile. local civic and commercial gromps are working to attract enterprises from ontside the area and to develop conterprises locally:

\section{People and Farms in the Valley}

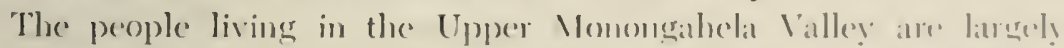

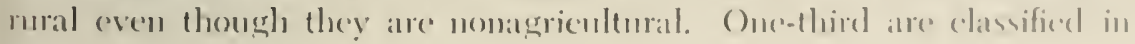


the 1950 Census as urban and are concentrated in the industrial and mining centers that spread across the western and northem parts of the Valley. The eastem and southem parts of the area are less densely settled and a higher percentage of the people live in small towns or in the open country. Two-thirds of the rural people in the Valley are classified in the Census as nonfarm. Some of these people live in small towns or villages but many live out in the open country-often on holdings of $10,20,30$ or even 50 or 100 acres but they do not do enough farming to qualify as farmers under the Census definition. ${ }^{11}$ Either the slope of the land is too great, the terrain too rugged, or the timber growth too heavy to permit profitable agricultural effort.

Total population of the Valley was 357,113 persons in 1940 and $368,65 t$ in 1950. Total population change was not great but there was a pronounced shift of people from the rural to the more urban counties. This was in keeping with the industrial growth in the Valley during the World War II period.

Workers in the Valley were classified by occupation in the 1950 Census as follows:

$\begin{array}{lc} & \text { Percent } \\ \text { Agriculture } & 9.6 \\ \text { Farm operators } & 5.9 \\ \text { Farm laborers } & 1.3 \\ \text { Unpaid family workers } & 2.4 \\ \text { Mining } & 21.9 \\ \text { Manufacturing } & 17.2 \\ \text { Trade, retail and wholesale } & 15.4 \\ \text { Other nonfarm } & 35.9\end{array}$

Especially significant is the fact that fewer than 6 percent of the workers in the area reported themselves as farm operators. An additional 3.7 percent were either farm laborers or unpaid farm family workers.

These figures are in contrast to Census data on residence of the population, which show that 22 percent of the population in the Valley lived on farms. In other words, many people who reported their occupation as miner, factory worker, or other nonfarm worker lived on places classified as farms. On the other hand, many other nonfarm workers also lived out in the open country but on acreages that did not in 1950 meet the Census requirements for a farm.

The distinction between "farm" and "nonfarm" for the acreages in this area therefore is not one of occupation but of residence. Most of the "farm" families had a few more chickens or a better cow than their

II In the 1950 Census, places of 3 or more acres were counted as farms if the value of agricultural products, exclusive of home gardens, amounted to $\$ 150$ or more. Places of less than 3 acres were counted as farms when the value of sales of fam products amounted to $\$ 150$ or more. 


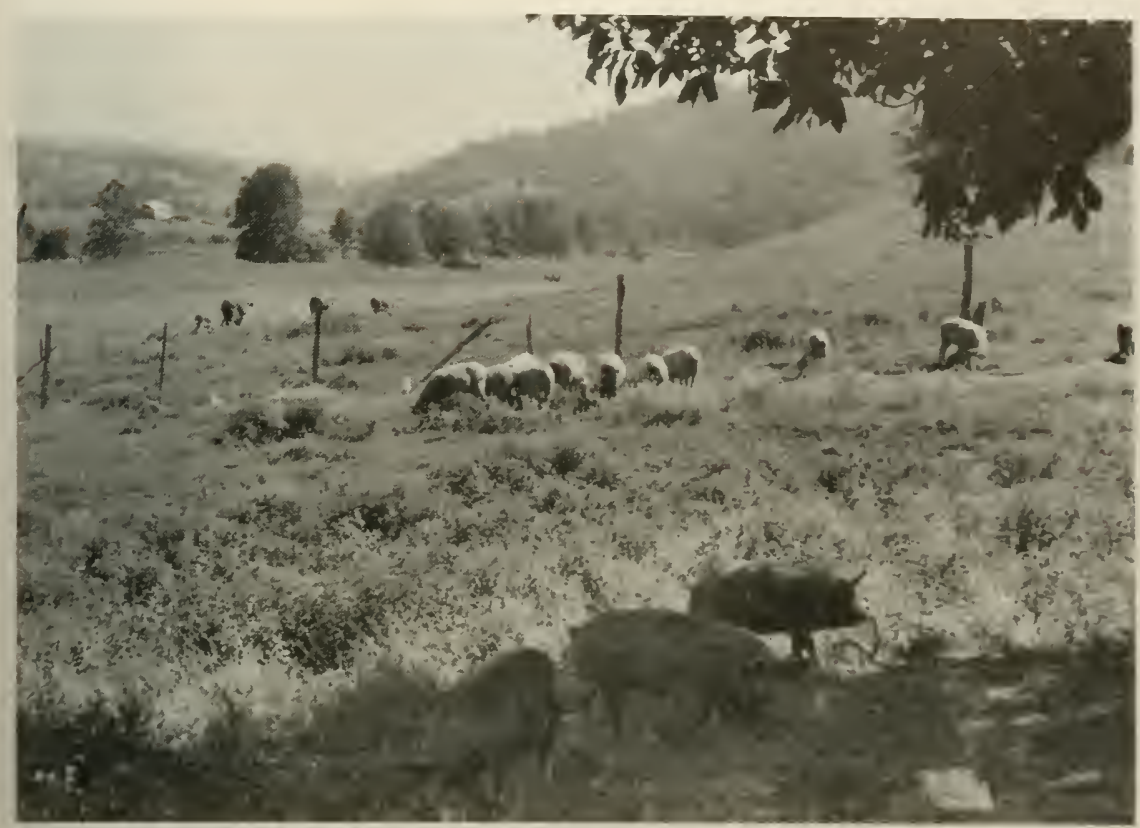

FIGURE 3. The small West Virginia farm typicaliy has a few head of livestesk and small acreages in hay ond grain.

neighbors who were classified as "nonfarm." The same family might easily shift between the "farm" and "nonfarm" classification from year to year depending on the yield of their crops or how well their hens lay:

The foregoing discussion indicates that the farming operations of most residents of the area are supplementary to their nonfarm activities. According to the 1954 Census of Agriculture the nonfarm incomes of 52 pereent of the "farm" households in the Valley exceeded the value of farm products sold. Likewise almost 60 pereent of the "farmers" worked off their farms in 1949, and about 4.5 pereent worked off their lams for more than 100 days. Even those "farmers" who dich not work off their farms were often retired or disabled people whose matin souree of support was a pension or public assistance pilyments.

Consecpuently it is not smprising that apporosmately halt of the 17,00() farms in the Villey were classified in the Cousus as resichential. that is, with less than $\$ 250$ worth of farm produce sold from them doriun the preceding year (Table 1). An additionil 21 perecent of the filme

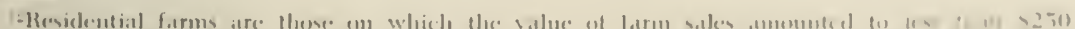

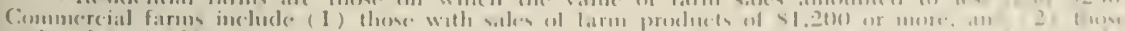

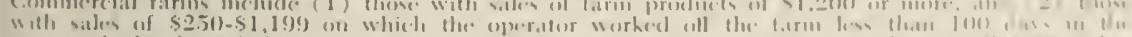

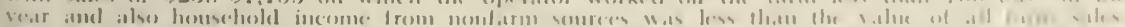

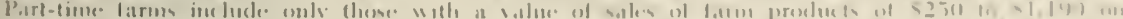

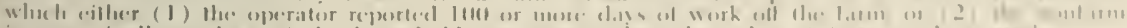

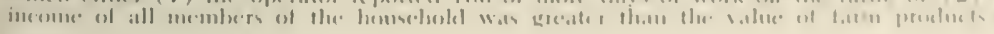




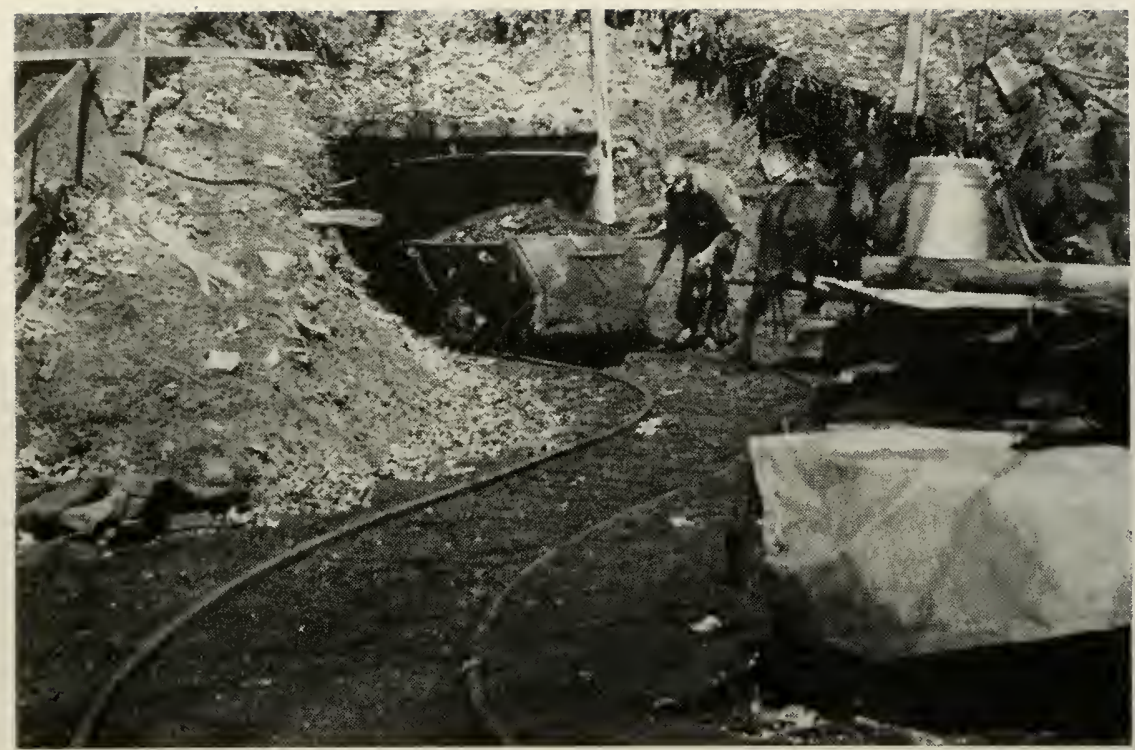

FIGURE 4. Equipment in a marginal operation of this type is brought up to date very slowly and labor is used at varying rates of efficiency.

were classified as part-time. These also are small, reporting less than $\$ 1,200$ in sales, and the operator either worked off the farm more than 100 days or the nonfarm income of members of the household was greater than the total value of farm products sold. For the most part the residents on both these types of farms were nonfarm workers who did a small amount of farming on the side.

Hence, in 1954 only 30 percent of the farms in the Valley were classified as commercial. Half or more of the households on these farms had incomes primarily from agriculture. Almost half came within the class of farms with sales of from $\$ 250$ to $\$ 1,199$ on which both $(1)$ the operator worked off the farm less than 100 days during the preceding year and (2) houschold income from nonfarm sources was less than the value of all farm sales. The rest of the farms, almost 15 percent of the total, had gross sales of farm products of $\$ 1,200$ or more. Operators of some of those farms had nonfarm activities and incomes that were greater than their farming operations.

Agriculture occupies a minor role in the economy of the Valley. The welfare of its growing population depends largely on the expansion and 


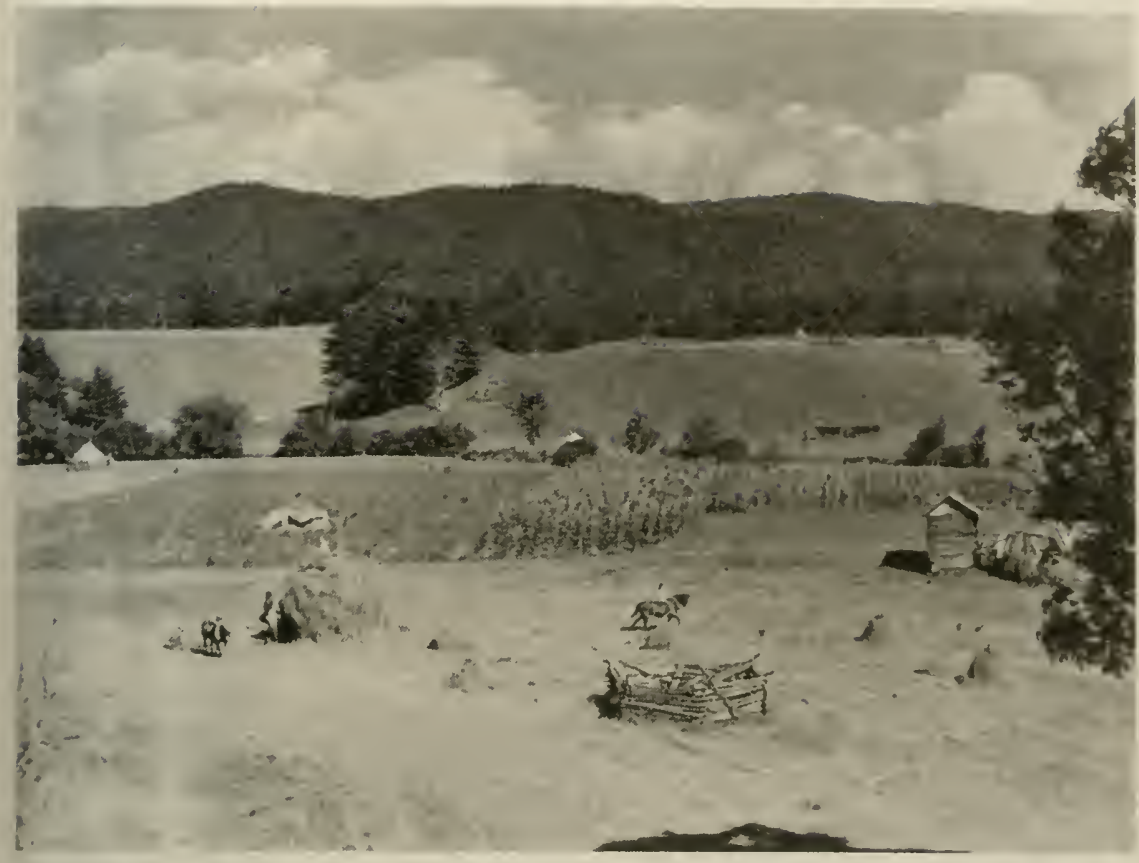

FIGURE 5. Some small-scale forms in West Virginio still use traditional methods of haying.

maintenance of industrial employment. Workers use farming to supplement their nonfarm activities, but this is not extensive enough to provide much of a cushion in times of inclustrial slowdown or individual mon-mployment.

On an age basis. the population in the Upper Monongihela Vialley differs from that of the United States generally in that a somewhat larger percentage of the people are in the young- and the old-age brackets. The percentages from the 1950 Census were as follows:

$\begin{array}{lcc}\text { United } & \begin{array}{c}\text { Upper } \\ \text { States }\end{array} & \begin{array}{c}\text { Mononqahelo } \\ \text { Valley }\end{array} \\ \text { Under } 24 \text { years old } & 41.6 & 45.5 \\ 2.5 \text {-64t year old } & 50.3 & 46.0 \\ 6.5 \text { years and over } & 8.1 & 5.5\end{array}$

This means that a higher proportion of the population in the lalley are young people who are entering or rearly to enter the labor force. Whether they will make their work contribution lecally or alsewhere in the United States depends on the development of employ ment oppontunities in their home area. The smaller proportion of adule probulsh reflects the effect of migration from the Valley: 


\section{Households and Workers In the Sample Group}

This survey was designed to ascertain the extent of employment and underemployment of open-country rural people. Households in cities and in towns or villages of more than 100 population were excluded from the sample. The open-country people were largely nonagricultural, but adequate coverage was obtained for both the agricultural and the nonagricultural groups in the population. A randomized sample of households that would be representative of open-country people in the Valley was drawn on an area segment basis.

The results of the survey apply specifically to open-country households in the Valley. However, since all nonfarm groups in the Valley are dependent on the same mines, mills, and other employment outlets as the workers in this sample, the nonfarm aspects of the findings also apply rather closely to the more urban sector of the population in the Valley.

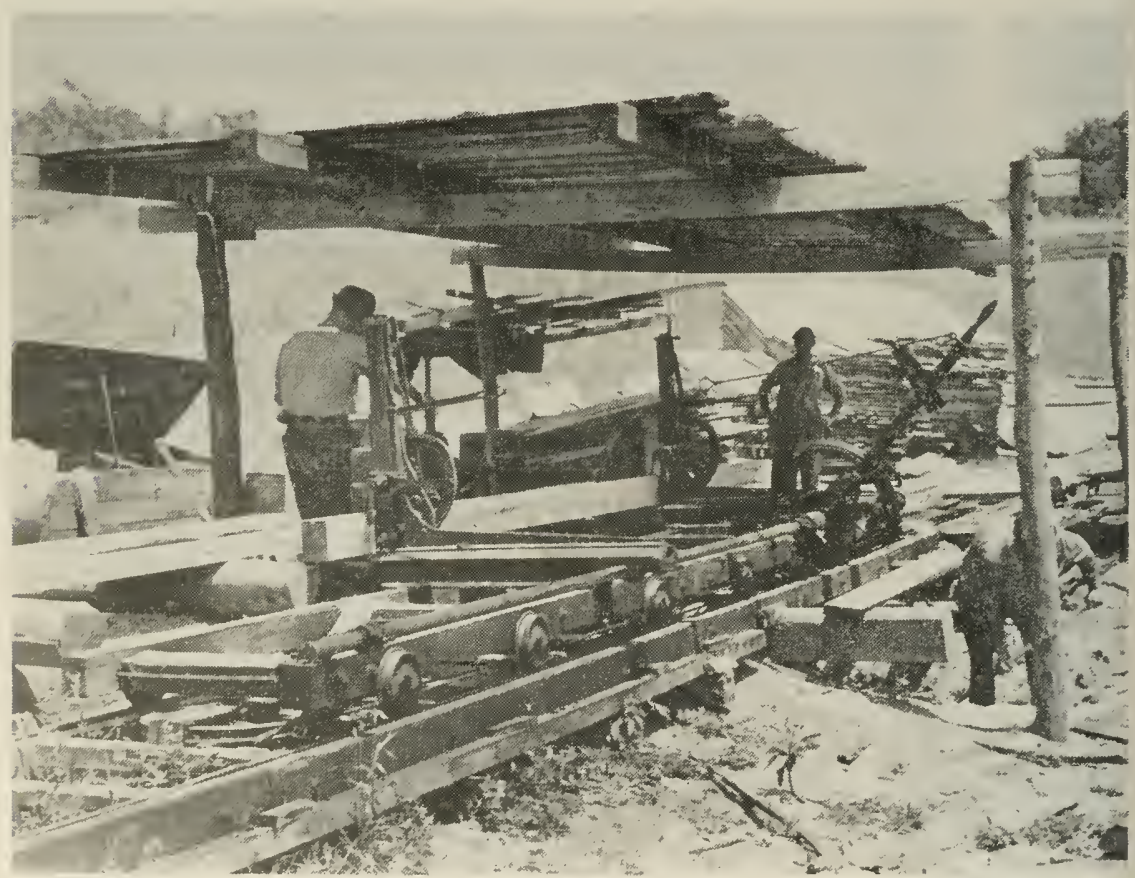

FIGURE 6. Work in sowmilling operations has been very steady during this period of rapid building construction. 
Information was obtained in the field survey in regard to 575 households which contained 3,418 people. A 12 -month employment record was obtained for all persons 14 years old or over in those households. This covered all work on the home farm or in the home business as well as work for other people. There were 2,257 persons in this age group, of whom 1.331 had done some work during the preceding 12 months.

On the same basis of classification as used in the 19.54 Census of Agriculture (see page 9), 36 percent of the sample households were located on tracts of land that would qualify as farms (Table 2). Furthermore, one-half of the farms they lived on were classified as residential, 21 percent as part-time, and 24 percent as commercial. These percentages correspond very closely to the proportions reported for the Valley by the 19.54 Census of Agriculture. Many of the other households were on fairly large acreages which clid not have enough agricultural production to cualify as farms.

Table 2. Type of Household, by Residexce ani Solize of lNcome. Upper Monovgahelia Valley, West Virgivia, July, 19.5. ${ }^{\circ}$

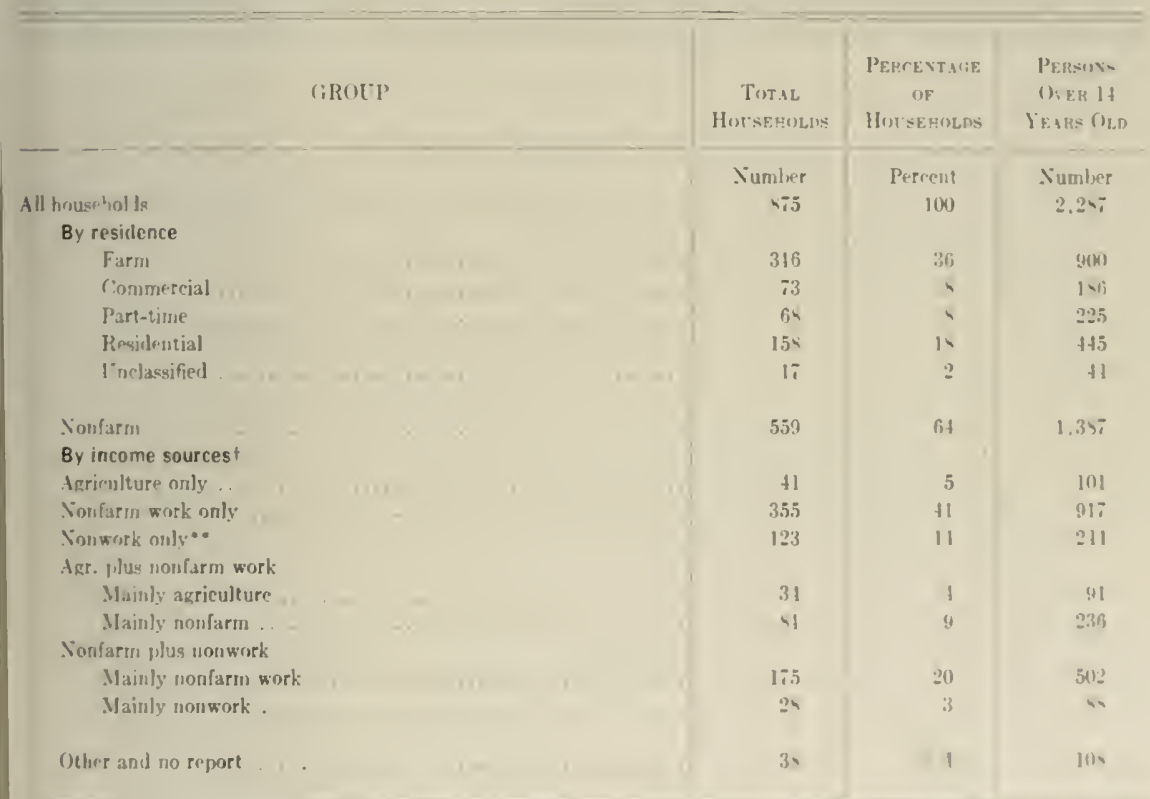

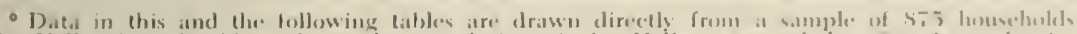

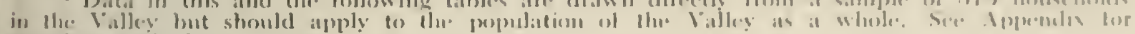
s.tmpling me thot.

† A fetwen farm, wonfarm work and nomorsh sumres.

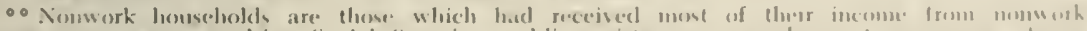

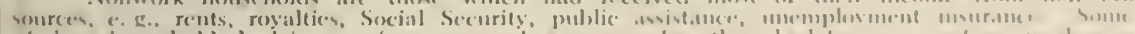

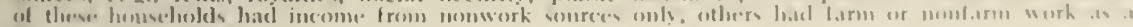
minor sturce of incomr. 


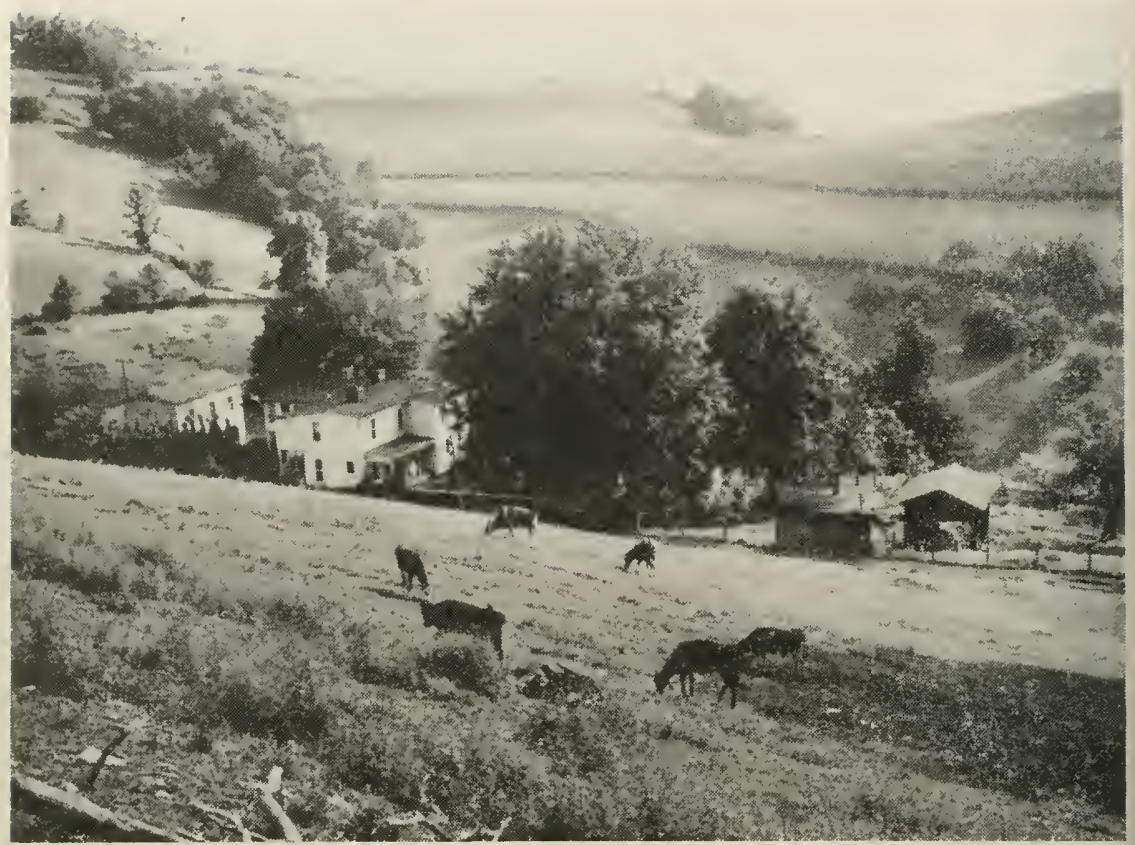

FIGURE 7. Some farmers use the most up-to-date practices in strip cropping and soil conservation.

Any classification on a farm-nonfarm basis of the places on which these people lived calls for some explanation. Some places were definitely farms, others were simply the homes of nonfarm workers and had no agricultural activities. The majority of the places, however, were the homes of one or more nonfarm workers on which a small amount of home production was also carried on. Home gardens were of varying sizes, but gardens did not qualify a place as a farm. A small flock of chickens or a cow might qualify a place of more than 3 acres as a farm but would not affect the classification of a similar place of less than 3 zcres unless milk or eggs were sold.

On the basis of income, only 5 percent of the households relied on agriculture alone. About 40 percent of them had income from nonfarm work alone and another 14 percent from nonwork sources only; The remaining 41 percent had income from two or more of these sources. Thirteen percent had income from both nonfarm work and the sale of farm produces. In such cases the nonfarm income was usually the more important source.

The term "nonwork income" has been used to designate income from royalties, rent, insurance, etc., as distinguished from income derived from 
wages, salaries, fees, or profits. Some households subsisted on nonwork income alone. There were 123 households of this type in the survey group. Their income came from two sources - first. from capital investment, such as rents, royalties, and interest; and second. from insurance. retirement, or relief funds, such as Social Security payments. unemployment insurance, retirement funds, workmen's compensation. and State relief. In addition to the households which subsisted on nonwork sources alone, there were 200 households which reccived nonwork funds of some type in addition to their other sources of incone.

\section{HOUSEHOLD SIZE}

Large households were not characteristic of the Valley. They usually. consisted of 2.3, or 4 persons, with the average being 3.9 . Since this survey deals with employment, data were obtained only in resard to persons classified as being in the labor force, that is, 14 years old and over. There was an average of 2.6 of these persons per household. The number did not vary greatly with the oceupation of the household head (Table 3). Nonwork households, however, were smaller. Two-thirds of these had only 1 or 2 persons old enough to be in the labor force, and these persons often were too old to engage in regular employment.

Table 3. Number of Persons 14 Years Old and Ovir Per Hotsiliold, by Industry and Level of Living, Upper Moxongahela Valley, West Virginia, July, 1954.

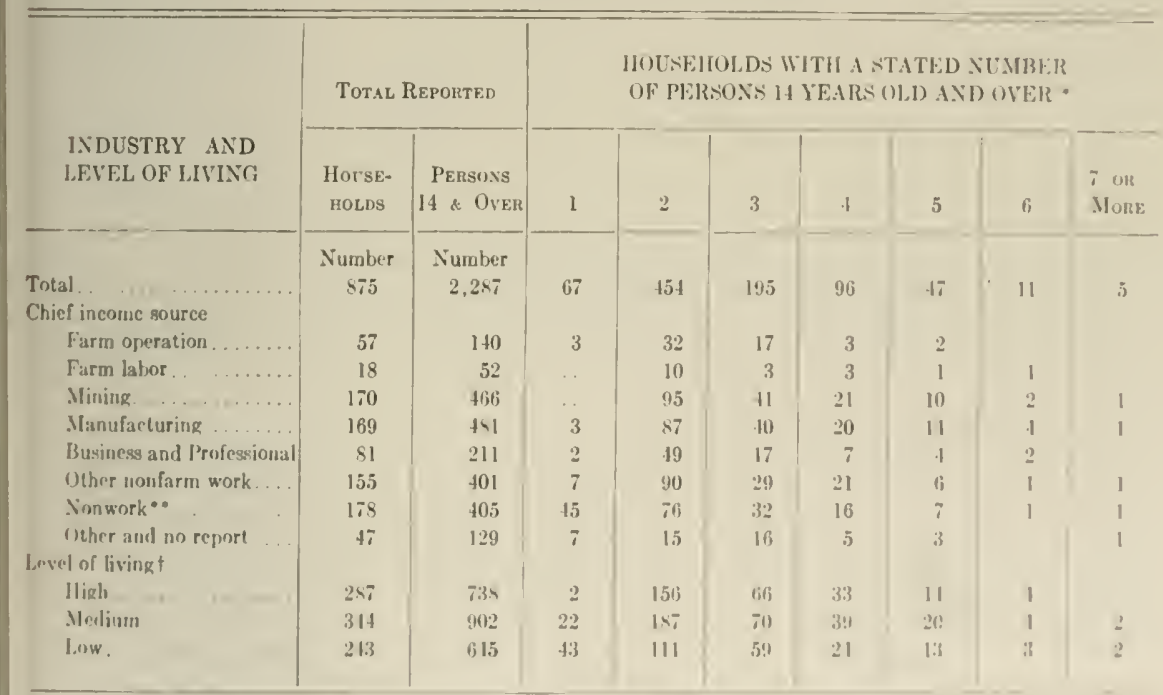

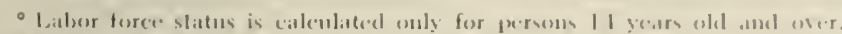

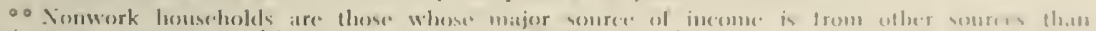

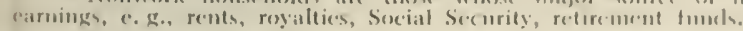

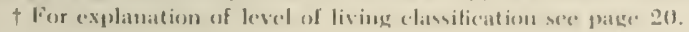


The age composition of the population clisplays the characteristics of a group from which young people have been leaving in order to obtain their livelihood elsewhere. A smaller proportion of the people are in the middle-aged group than in the nation at large and a larger proportion are in the groups under 24 and over 65 years of age (Table 4 ). The deficiency of young adult male workers is somewhat greater than of female workers. Apparently young men have been under more pressure to find employment elsewhere.

Table 4. Percentage of Persons 14 Yearis Old and Over Who Were in Selected Age Groups, Upper Monongahela Valley, West Virginia and the United States, 1954.

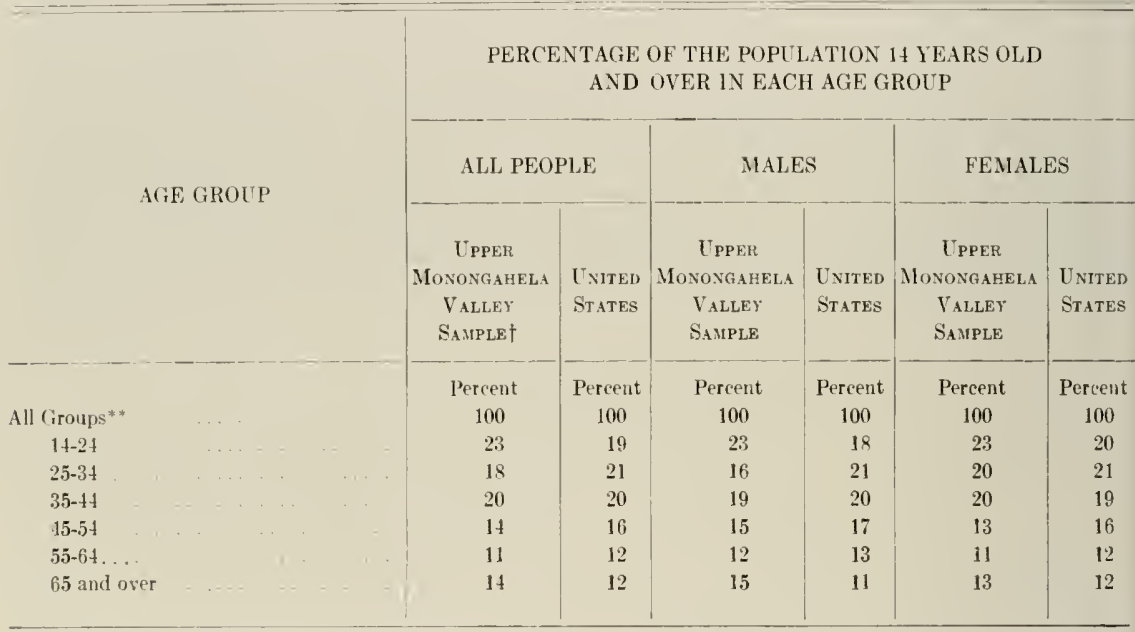

- Bureau of the Census, Current Population Reports Estimates of the Population of the United States, by Age, Color, and Sex July 1, 1950 to 1955, Sept. 1955.

$\leftarrow$ Open-country residents in Upper Monongahela Valley.

o Persons in this table limited to those of labor force age. They constituted 33 per cent of all persons in the sample area. Persons in this age group constituted 29 percent of the population of the United States in 1954.

\section{EDUCATIONAL ATTAINMENT}

The most common level of educational attainment of the people in the labor force is completion of grade school ( 8 grades) or slightly above. Forty-two percent, however, have had some high school or college training (Table 5). On the other hand, one-fourth did not complete grade school.

There was one outstanding aspect of the educational attainment of this group of people, namely, the great improvement in educational level of the people in the younger age groups. 
Table 5. Percentage of Persons 14 lears Old and Over Who Had Completed a Specified Number of Grades in School, by Age, Sex, and Industri Group, Upper Moxoxgahela Valley, IVest Virgivia, JuLY, 1954.

\begin{tabular}{|c|c|c|c|c|c|c|c|c|c|}
\hline \multirow{3}{*}{ GROLP } & \multirow{3}{*}{\multicolumn{2}{|c|}{$\begin{array}{l}\text { Total } \\
\text { Persons } \\
\text { Reportixe }\end{array}$}} & \multicolumn{7}{|c|}{$\begin{array}{l}\text { PERCENTAGE OF PERSONS WIIOSE HIGIIEST } \\
\text { GRADE COMPLETED WAS }\end{array}$} \\
\hline & & & \multicolumn{3}{|c|}{ ElEMEXTARY ŚCHnOL } & \multicolumn{2}{|c|}{ Hifin S̀rHont } & \multicolumn{2}{|c|}{ College } \\
\hline & & & $\begin{array}{c}0-3 \\
\text { YEARS }\end{array}$ & $\begin{array}{l}4-\pi \\
\text { YEARS }\end{array}$ & $\begin{array}{l}\text { S } \\
\text { YEARS }\end{array}$ & $\begin{array}{l}1-3 \\
\text { YEARS }\end{array}$ & $\begin{array}{l} \pm \\
\text { YeARS }\end{array}$ & $\begin{array}{l}1-3 \\
\text { YEALS }\end{array}$ & $\begin{array}{c}\text { IOOR } \\
\text { MORF }\end{array}$ \\
\hline & Number & $r$ & $r$ & $\because$ & $\because$ & $r$ & $\because$ & $r y$ & $r$ \\
\hline All persons . . . . . . . . . . . . I & $2,252^{*}$ & 100 & ij & 22 & $3 n$ & 20 & 16 & 4 & 2 \\
\hline By age and sex & & & & & & & & & \\
\hline Male. ................ & 1.114 & 100 & s & 23 & 31 & 15 & 11 & 4 & 2 \\
\hline $14-24 \ldots \ldots \ldots \ldots \ldots$ & 261 & 100 & 2 & 21 & 17 & $3 i$ & 19 & 4 & $\bullet$ \\
\hline $25-64 \ldots \ldots \ldots \ldots$ & 686 & 100 & $i$ & 21 & 36 & 14 & 11 & 5 & 3 \\
\hline 65 and over ..... & 167 & 100 & 21 & 35 & 36 & 3 & 3 & 1 & 1 \\
\hline Female...... & 1,134 & 100 & 5 & 21 & 29 & 21 & 18 & 4 & 2 \\
\hline $14-21 \ldots \ldots \ldots \ldots$ & $26 \pi$ & 100 & 1 & 9 & 15 & 46 & 2.1 & 4 & 1 \\
\hline $25-64 \ldots \ldots \ldots \ldots \ldots$ & 726 & 100 & 4 & $2: 2$ & 33 & 16 & 19 & 4 & 2 \\
\hline 65 and over.............. & 145 & 100 & 16 & 39 & 32 & 6 & 5 & 1 & 1 \\
\hline By chief income source & & & & & & & & & \\
\hline Agriculture. . . . & 190 & 100 & 9 & 22 & 39 & 12 & 12 & 4 & 2 \\
\hline Mlining $\ldots \ldots \ldots$. & 458 & 100 & 6 & 23 & 33 & 23 & 13 & 2 & \\
\hline Manufacturing......... & 475 & 100 & 6 & 20 & 24 & 23 & 19 & 3 & I \\
\hline Business and Professional.. & 211 & 100 & 2 & 16 & 23 & 25 & 23 & 9 & 2 \\
\hline Other nonfarm........ & 394 & 100 & 2 & 12 & 29 & 20 & 21 & 7 & 6 \\
\hline 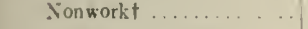 & 396 & 100 & 15 & $3 i$ & 24 & 11 & 7 & 1 & 1 \\
\hline Other and no report ...... & 124 & 100 & 3 & 22 & 31 & 23 & 15 & 3 & 3 \\
\hline
\end{tabular}

- 3.5 persons did not report.

$\circ$ Less than 0.5 percent.

Comparative ctatia for the United States: Less than high school edueation, 17 percent; high schoml: 1-3 vears, 21 percent; 4 veits, 22 percent; college: 1-3 years. 7 jercent; 4 years, 1 percent. Bureati of the Census, Current Population Reports, Octuluer, 19.52.

+ Nomwork houscholds are those whose major income " was from nomwork sources, e. ge, rents, royaltie's, Social Security, retirement furds.

In the age group $14-24,60$ percent of the young men and 7.5 pereent of the young women had some education beyend grate scheol. It the other extreme, only 8 pereent of the men and 11 perecnt of the women over 65 had any education beyond grade scheos.

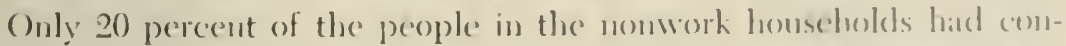
timed their education past grade school. This is chescly assectiated with the fact that many of them were in the older ange cresulus.

\section{VOCATIONAL TRAINING}

The perple in this areal had mam! shills allener inclustrial linues. Therir employment in mines, mills, and factories attested to that fict. In adeli- 
tion, some had taken special training to qualify for a particular vocation. as shown in Table 6. Those workers who had learned on the job, or had taken safety courses or other special classes, are not included in the tabulation.

Table 6. Peisons With Special Vocational Training, by Sex and Source and Type of Training, Upier MoNongahela Valley,

IVest Virginia, July, 1954.

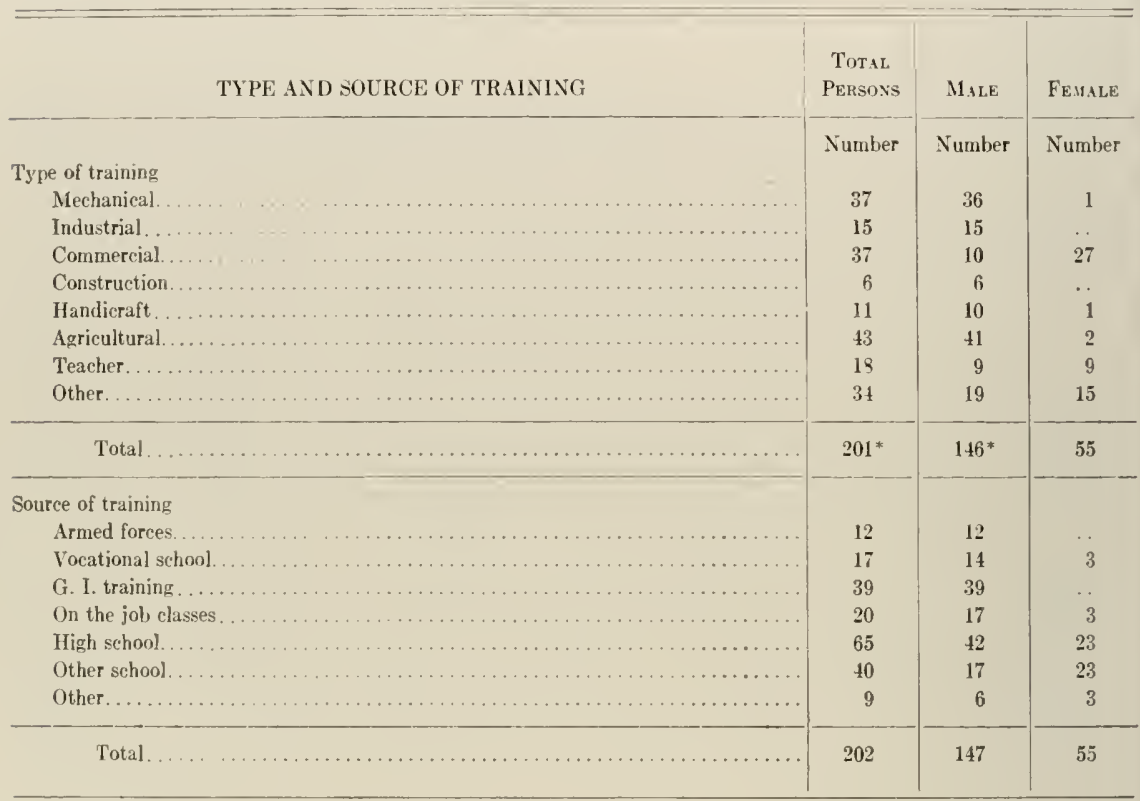

* One worker did not report type of training.

More workers had taken courses in vocational agriculture than any other single type, but almost as many had taken courses along commercial or mechanical lines. Some of these courses were taken in high school, and others in business college or night school. More than 50 of the young men had taken special vocational training either in connection with the armed forces or veterans programs.

\section{LEVEL OF LIVING}

Households in the Valley generally had rather modest levels of living. A rough scale to measure relative level of living was developed on the basis of possession of the following items: electric lights, water piped in home, electric or gas refrigerator, deep freeze mit or locker rental, power washing machine, automobile or truck, flush toilet, kitchen sink, telephone, daily newspaper. Average score for the households covered 
by the survey was possession of 6 of the 10 items listed. The items that were most frequently lacking were deep freeze unit, flush toilet, telephone, and daily newspaper.

Eight percent of the households had all 10 of the items, whereas 4 percent had only one of them. A total of 28 percent had from 1 to 4 of the items and were classed in the "low" level-of-living group, 39 percent had from 5 to 7 of the items and were included in the medium level-of-living group. The top $3: 3$ percent had from 8 to 10 of the items.

\section{COMPARISON WITH OTHER SURVEYS}

Comparison will be made at several points in this report with results of surveys made in two other "labor surplus" areas, eastem kentuchy and southeastern Oklahoma. These results are reported in Rural Manpower in Eastern Kentucky by Robert E. Galloway and A Study of Rural Manpower in Southeastern Oklahoma by James O. Tarver.:" In all three areas, agriculture, coal mining, sawmilling. and miscellaneous industries are important elements in the local economy. The area in West Virginia is the most highly industrialized, with relatively fewer open country people depending on agriculture.

\begin{tabular}{|c|c|c|}
\hline & $\begin{array}{c}\text { Percentage of open- } \\
\text { country households } \\
\text { that engage in } \\
\text { farming }\end{array}$ & $\begin{array}{l}\text { Percentage of } \\
\text { male heads who } \\
\text { did nonfarm } \\
\text { work }\end{array}$ \\
\hline $\begin{array}{c}\text { Upper Nonongahela } \\
\text { Valles; W. Va. }\end{array}$ & & 72 \\
\hline astem Oklahoma & 54 & 54 \\
\hline tern 'Kentucky' & 60 & 46 \\
\hline
\end{tabular}

The Oklahoma area has been the home base for a Iarge number of migratory workers. In 1952 an estimated 12,000) workers left the area for seasonal work. This was only half as many as had been leaving prior to the heavy labor demands which accompanied the horean conflict. Vigrants were not numerous in the Kentucky and West Virginia areas.

\section{Activities and Occupations of Open-Country People in the Valley}

The perople in the survey area were typically "hill folks." Thee expressed a preference to stay in their megerd sumbundings aven if it meant some saterifiee in incone and economice status. Aceordingly there were mumerous genth and other people living in the leouselualds in the area who ordinarily miglat be expected to lease home to mothe their own

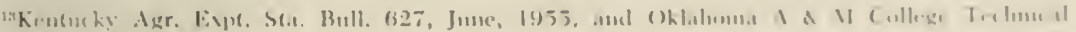
13ull. $l^{\circ}-36$, sipt. 19.5.5. 
living. Economic circumstances, however, were causing some people to recheck the values of living in the Valley against economic potentialities elsewhere.

Each person interviewed was asked to classify all members of the household 14 years old and over according to their major activity during the preceding 12 months. Ordinarily this was done without difficulty. Crown sons and daughters still at home and not working constituted the most difficult group to classify. There was a tendency not to report them as unemployed unless they were actively looking for work. Some were reported, instead, as unpaid family workers, others as keeping house, and a few as unemployed but not looking for work, depending on the circumstances of the particular case. They constitute a fringe group of people who have had difficulty in starting out for themselves, either due to the slack local employment situation or to other circumstances.

Other people who presented some difficulty in classification were the retired and disabled. Some were both retired and disabled. Others who were retired or partially disabled still did a good deal of farm work and reported as farm operators.

People in the two foregoing classifications constituted a significant proportion of all persons covered in the survey. They account in part for the small proportion, 42.8 percent, of the persons 14 years old and over who can be classified as being mainly in the labor force. (See Table 7). ${ }^{14}$

A total of 74 percent of the males and 12 percent of the females reported working or looking for work as their major activity during the previous year. These percentages are directly comparable with the results of special surveys made in eastem Kentucky and southeast Oklahoma, which are also "labor surplus areas."15 The percentage of workers 14 years old and over mainly in the labor force for the three areas is as follows:

\section{Percentage who were mainly in labor force West Virginia Kentucky Oklahoma}

All workers 43

Male

Female 12

40

*

* 78 percent of the male heads and 19 percent of the other people reported they were mainly in the labor force during the previous year.

${ }^{14}$ See monthly issues of Current Ponulation Reports, Labor Force, U. S. Bureau of the Census. Persons in the labor force include those 14 years old and over who were (i) employed during the survey week, including members of the armed forces, and (2) unemployed and looking for work. This latter group includes workers who were not looking for work because (1) they were temporarily ill, or (2) were temporarily laid off, or (3) they believed no work was avajlable.

${ }^{75}$ See Rural Manpower in Eastern Kentucky by Robert E. Galloway, Ky. Agr. Exp. Sta. Bull. 627, June, 1955, and A Study of Rural Manpower in Southeastern Oklahoma by James D. Tarver, Oklahoma A \& .1 College Technical Bull. T-56, Sept,, 1955. 
Table 7. Major Activity of Persons 14 Years of Age axd Orer Dering the 12 Morths Precedng the Sunvey, by SeX and Faimly Status, Upper Moxongahela Valley, West Virginla, July, 1953.

\begin{tabular}{|c|c|c|c|c|c|c|c|c|}
\hline \multirow{2}{*}{ MAJOR ACTIYITY } & \multirow{2}{*}{$\begin{array}{l}\text { Total } \\
\text { Persoss }\end{array}$} & \multicolumn{3}{|c|}{ MALE } & \multicolumn{4}{|c|}{ FEMALE } \\
\hline & & HE.ADg & Soss & Others & HEADS* & Wives & $\begin{array}{l}\text { DSTGH- } \\
\text { TERS }\end{array}$ & OTHERS \\
\hline All persons.... & $\begin{array}{c}\text { Number } \\
2.257\end{array}$ & $\begin{array}{l}\text { No. } \\
792\end{array}$ & $\begin{array}{l}\text { No. } \\
262\end{array}$ & No. & No. & $\begin{array}{l}\text { No. } \\
730\end{array}$ & $\begin{array}{l}\text { No. } \\
235\end{array}$ & $\begin{array}{l}\text { To. } \\
106\end{array}$ \\
\hline Mainly active in the labor force....... & 978 & $0 \$ 1$ & 113 & 41 & 16 & 70 & +1 & 13 \\
\hline 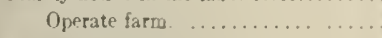 & 149 & 129 & 4 & 1 & 5 & 10 & .. & . \\
\hline Farm wage work $\ldots \ldots \ldots \ldots$ & 23 & 17 & 5 & 1 & & .. & & .. \\
\hline Nonfarm en.jyloyment........ & 641 & 460 & 51 & 27 & 10 & 51 & 30 & 9 \\
\hline . Nonfarm lusiness or prof..... & 53 & 42 & 1 & 2 & .. & 5 & 3 & . \\
\hline Armed forces $\quad . . . . .$. . & 24 & 5 & 15 & 3 & .. & .. & .. & 1 \\
\hline Vnpaid famuly work. .............. & 35 & 2 & 14 & 4 & .. & 4 & 8 & 3 \\
\hline Looking for work . . . . . . . . . . & 54 & 27 & 20 & 3 & 1 & . & 3 & . \\
\hline Mainly not active in labor force.. & 1,309 & 111 & 149 & 35 & 67 & 660 & 194 & 83 \\
\hline Going to sehaol $\ldots \ldots \ldots \ldots$ & 293 & .. & 134 & 14 & .. & .. & 125 & 10 \\
\hline Keeping house ................ & $\$ 30$ & 1 & 1 & .. & $5 f$ & 654 & 63 & $5 i$ \\
\hline Retired.................... & 67 & 54 & .. & 9 & . & .. & .. & + \\
\hline Totally dizabled ................ & 61 & 22 & 3 & 8 & 8 & 5 & 3 & 12 \\
\hline Partially disabled.............. & 51 & 25 & 4 & 4 & 5 & 1 & 3 & 9 \\
\hline $\begin{array}{l}\text { Not employed and not looking for } \\
\text { work }+\ldots \ldots \ldots \ldots \ldots \ldots \ldots \ldots \ldots\end{array}$ & 17 & 9 & 7 & & & & & 1 \\
\hline
\end{tabular}

- Inchude both single women living by themselves and wives whose husloands had died, been divorced, or had left home.

$\pitchfork$ People who gave this reply had sufficient resources at the time of the interview that they did not need employment immediately.

The greater industrial development in West Virginia probably accounts for its higher percentage of persons in the labor force.

\section{HOUSEHOLD STATUS AND CHIEF ACTIVITY}

The activity most frequently reported for heads of households was some type of nonfarm employment. For approximately two-thirels of the male heads of houscholds, nonfarm work, business or profession wats their major activity (Table 7 ). One-sixth gave operating a farm ats their major activity; 1 out of $S$ were either retired or disabled. A small number were unemployed for the greater part of the year.

The wives of heads of houselolds ordinarily were not in the labur market but spent the major part of their time heeping house. Ninets pereent of them reported houscheeping as their majour activity, and fewer than $S$ percent reported any nonfarm employment.

Female heads of homseholds had activity patterms similar to theme of wives except that more of them were active in the labor forese. (O)ls 
65 percent gave housekeeping as their major activity. while a comparatively high percentage gave farm operation and nonfarm employment. A greater incidence of disability, 16 percent as compared to 1 percent for wives, probably is associated to some extent with the fact that State relief payments are made only to heads of households who are disabled.

About half of the sons and daughters 14 years old and over were in school. One-fourth of the daughters 14 and over spent their time at home helping with the housework. Only 15 percent had obtained employment in nonfarm work. Some of the sons had spent most of their time in the armed forces, but about 20 percent were engaged chiefly in nonfarm work. About 8 percent had spent the major part of the year looking for work.

In addition to members of the immediate family, the respondents reported on more distant relatives and nonrelatives in the household. About one-fourth of these people were retired or disabled and another 15 percent were children in school. Half of the women among this group spent their time in housework, and about 40 percent of the males spent their time in nonfarm work.

The fact that 135 women other than wives and female heads of households reported either keeping house or unpaid family work as their major activity points to a potential group of underemployed or unemployed women. These women continued to live with parents or other relatives in exchange for assistance in housekeeping.

When the activity pattems of the entire sample of workers are observed on an age and sex basis, the high proportion of farm operators in the older age groups becomes apparent. More than one-third were 65 years old or over (Table 8 ). Only 2 of 148 farm operators were under 25 years old. Moreover, a considerable amount of disability showed up among men less than 65 years old. Almost half of the (totally or partially) disabled males were under 65 years old. Disability of women under 65 was much less common.

\section{TYPE OF EMPLOYMENT}

All persons who did any work during the previous 12 months were classified according to both industry and occupation. This group includes many more persons than those who gave farm or nonfarm work as their major activity during the year. These were largely school children and housewives and were especially numerous in the field of agriculture. Instead of 171 persons who said their major activity had been in farm operations or hired farm labor. 437 now appear as having done more work in agriculture than at any other occupation (Table 9). The number of workers who did nonfarm work did not increase as much, due largely to 
Table S. Major Activty of Persovis 14 lears Old and Oler Detring the 12 Months Preceding the Survey, by Sex Axid Age, U'pper Monongahela Valley, West Virginla, July, 1954.

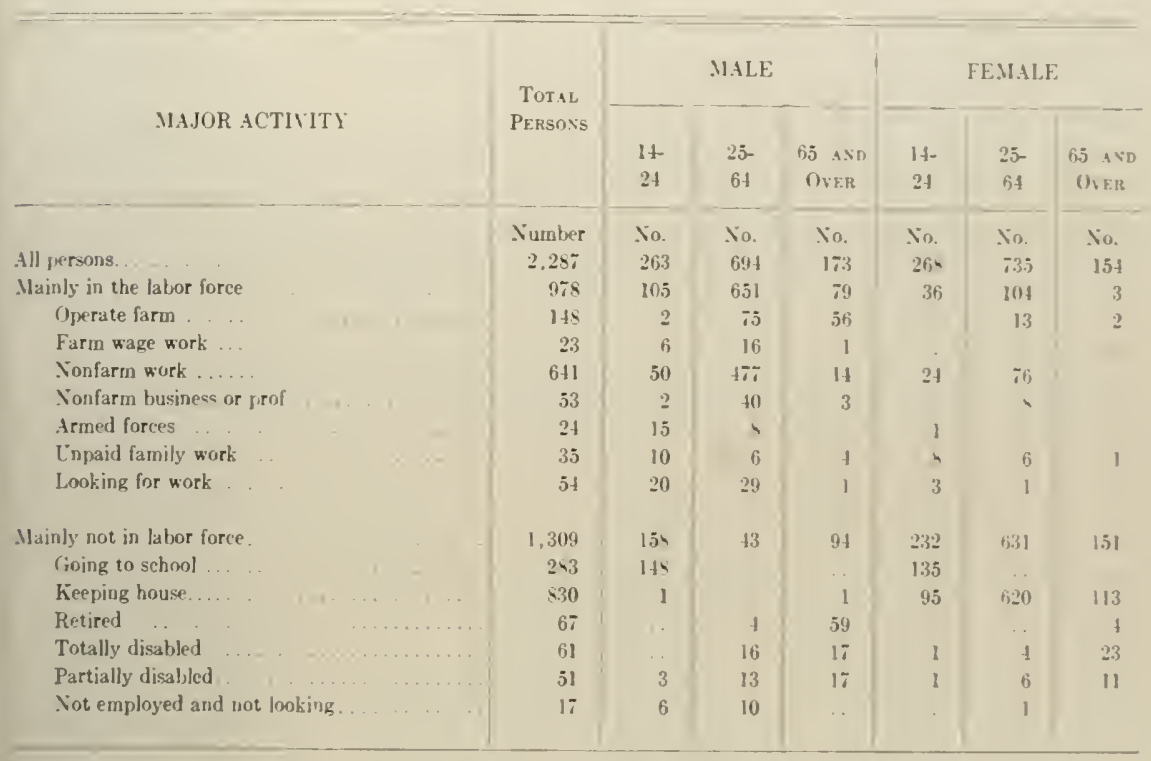

less employment of housewives and students. An exception was in the number employed in small stores. shops, and other businesses which were sometimes conducted as family enterprises.

The data indicate that many more wives than husbands were ('mployed in agriculture. Many of the male heads of houscholds who operated farms and also had nonfarm jobs reported their nonfarm employ ment as being their major occupation; hence ihey were classificel in some nonfarm-work category.

A third of all the persons who worked had their major employment in agriculture. about 1.5 pereent in mining, and a like pereentage in husiness and in miscellaneous types of manufacturing.

The foregeing sitnation must be kept in mind when the indisiclual workers are classified on the basis of length of employment and amemut of income. (On the basis of empleyment alene. one-thirel of all persoms who worked had their major employment in agriculture. But almost twothirds of the workess in agrienlture worked on the home farm only and received no paly. Their amount of farm worh ordindrily wats menterent.

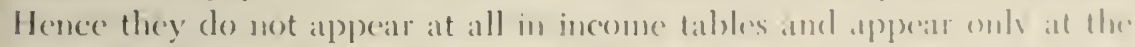
low end of length-of-emplonement tabulations. 


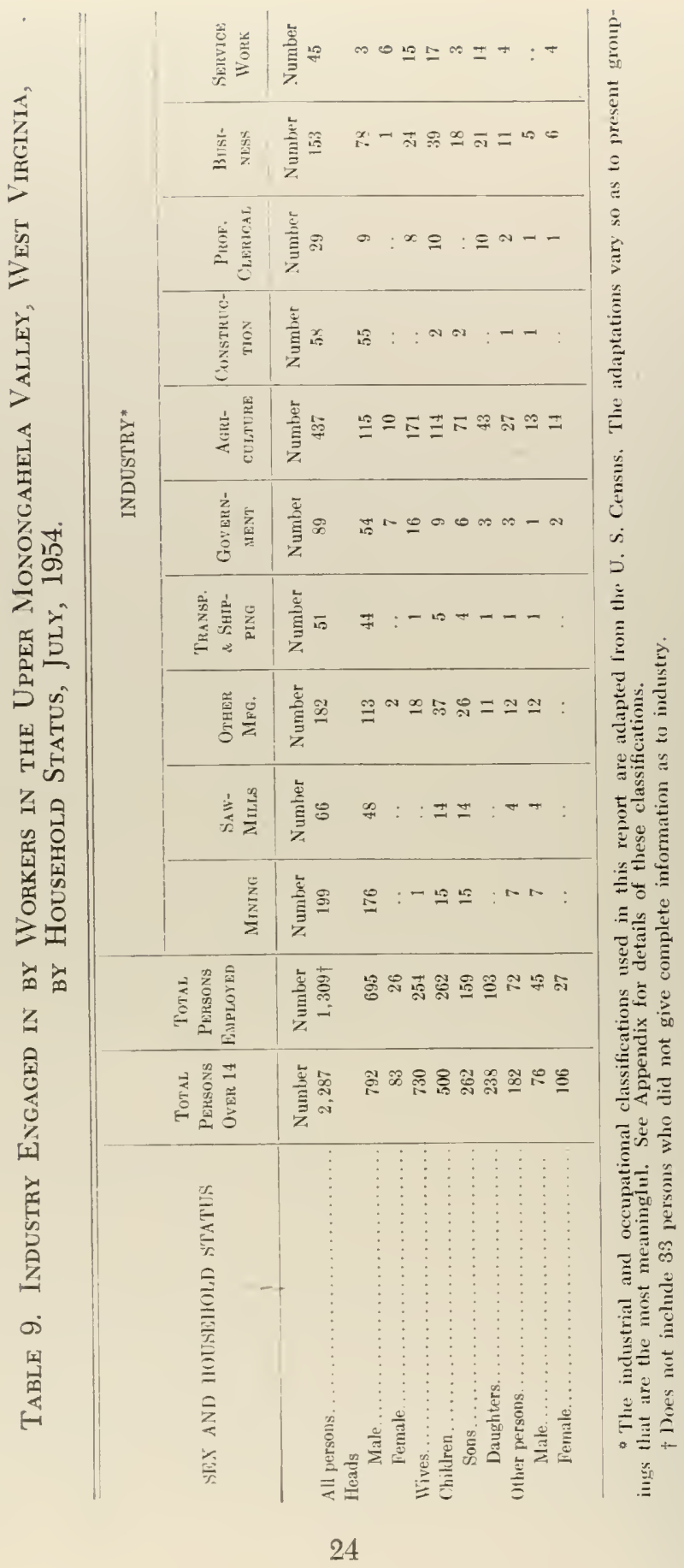


The workers reported on had a wide variety of work experience and skill. Some operated businesses of their own, others were managers, superintendents, or foremen. Many more were shilled workers in the establishments in which they were employed (Table 10). Workers in the mines, for example, were sometimes skilled carpenters, mechanics. electricians, or engineers. WVorkers in other business or manufacturing (establishments likewise often reported specialized skills and experience. Hence the residents of this area are not a group of farmers unfamiliar with the skills called for in present-day industrial operations. Ordinarily their skill in agriculture may be more limited than along nonfarm lines of work.

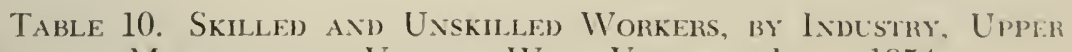
Monongahela V'alley, West V'mginia, July, 195.54.

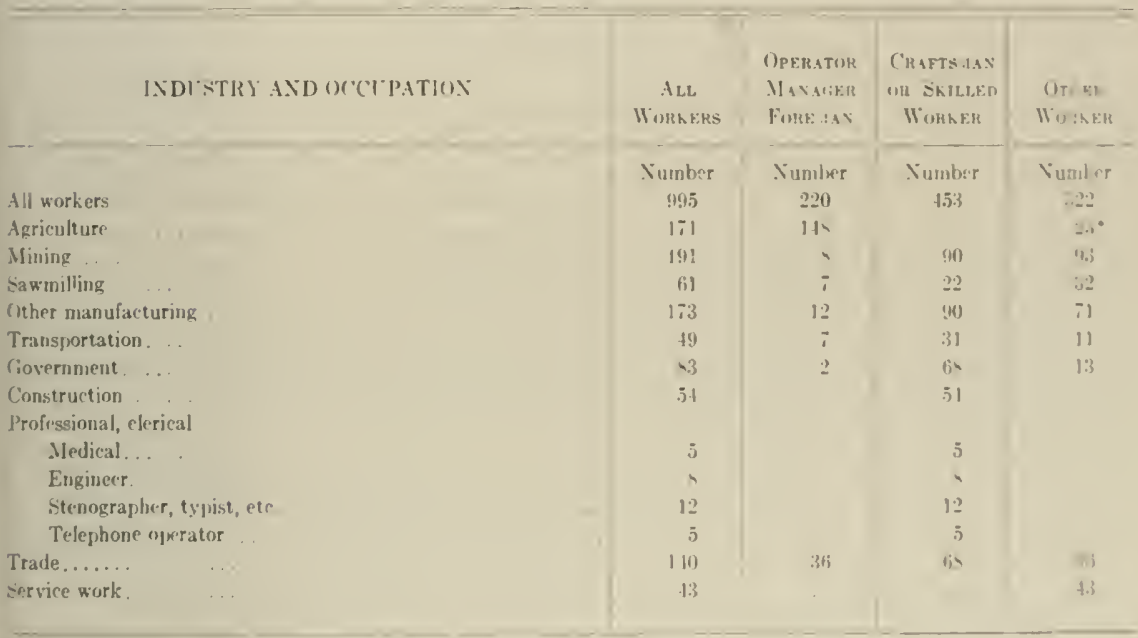

- Data prescruted show farm operitors and farm-wage workers only. They do not anclude 266 mipisid workers on larms. Unpatid workers along other lines are also omitted.

\section{Employment and Underemployment of Workers in the Valley}

Irregular and seasonal employment has been a problem in conl mining areas for many years. Development of mining operations hats hemelat about a decrease in the number and size of famms. ${ }^{16}$ Stuctents of this problem recommended 20 years age that miners live on subsistence farme and that woodworking and other seastumbl indestries be established to offset the seatsonality in coal mining empleyment.

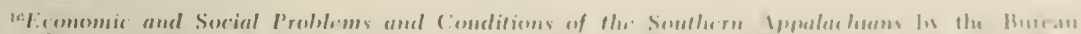

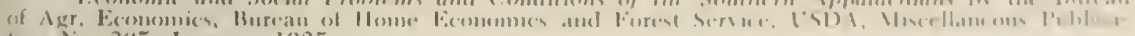
timi Vio. 2015, Jamiary, $1933 \%$. 
In areas with good agricultural resources, it is practical for mining and other industrial workers to supplement their nonfarm work by engaging in part-time farming. In many coal mining areas, however, poor soil and rugged terrain limit profitable agricultural operations.

The present situation may be more serious, however, than seasonal changes. If mechanization of mining operations continues, miners are likely to need more than supplementary employment in agriculture. Either new industries will have to be developed in the area or the workers will have to leave.

Underemployment in the Upper Monongahela Valley is by no means solely a mining or an industrial problem. Even the commercial farms in the Valley are in a somewhat marginal position. They compete with large, well-financed farms in the more fertile areas of the nation. Few of the Valley farmers are able to do this to advantage. They find it desirable to seek supplementary employment in order to have an adequate income. Since mining employment is undependable, a combination of farm and nonfarm work may still fall short of affording complete economic security unless new and more stable industries locate in the area.

\section{METHOD OF ESTIMATING EMPLOYMENT AND UNDEREMPLOYMENT}

As effort was made to ascertain how many days each person 14 years old and over had worked during the 12 months preceding the interview. In regard to hired farm or nonfarm employment, each respondent reported the number of days worked by each member of the household. Days of work on the home farm constituted a more difficult problem. Farmers had less identifiable bases on which to make a statement of days worked by each member of the household. Hence a special procedure was developed for estimating days of work on the home farm.

People who lived on acreages that qualify as farms under the Census definition were asked to give the number of acres in each crop grown, the number of all types of livestock, the types of machinery used, and the total amount of product for each of their enterprises. ${ }^{17}$ Each farm respondent was also asked to estimate what percentage of the total amount of work on the farm had been done by each member of the household. Data were available at West Virginia University on the amount of labor recuired for all farming operations in the State at different levels of technology. From these, total man-hour equivalents were computed for each farm covered in the survey. Total man hours for the enterprise were dividerd between the members of the household according to the percentage estimates made by the farmer. This procedure provided the

${ }^{1}$ Days of work on acreages that did not quality als farms were not asked for. In only a few cases were the se of any real importance. 
number of deys of farm work clone by each member of the farm household during the previous year.

It is difficult to establish a norm for full or aderuate employment as contrasted with underemployment. Such a norm would vary with the age and physical capacity of the worker. It would also vary with sex and status in the household. Underemployment is not entirely a matter of days worked but also exists when there is underutilization of a worker's skills and abilities. e.g. when a shilled engineer or electrician is reanlarly. employed at digging ditches, washing ears, or other unskilled or semishilled work. Some studies have arbitrarily set 180 days as the norm for adequate employment." No such precise yardstick will be applied in this survey. The determination of underemployment is still yuite roush and will be spoken of only in general terms. The schoolteaches teaching 170 days in the year probably is adecpuately employed as the term "full employment" is commonly used. Some small store and filling station operators with small numbers of customers appeared to be greatly under(mmployed even though they reported working 36.5 clays in the year.

Farm operators were not given an opportuitity to make a similar we'statement of the actual number of days worked. Their work-time was figured on the hasis of the actual amount of time nomally recuired to perform the operations on their farms. Hence a more reliable measure of the employment of farm people is provided than of operators of nomfarm businesses.

\section{TOTAL DAYS WORKED PER PERSON}

()f the 2.25 t persons 14 years old and orer corred hy the surve?. 1,342 , or 59 pereent, had done some work during the previous 12 month (Table 11). This figure compares with the $4: 3$ percent pres iensly mentioned who had reported some type of farm or nonfarm wouh as thain major activity. Therefore, 16 percent of the workers were primaril! houscrives, students, or retired or disabled persons.

The number of nomworkers, 41 pereent. rums aboue that for the nation generally but is uot quite as high as in some of the surplus laben

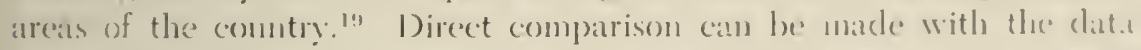

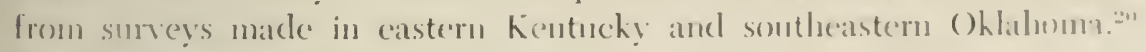
The figures are as follows:

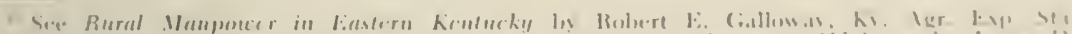

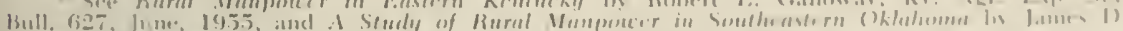

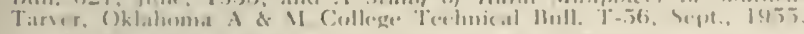

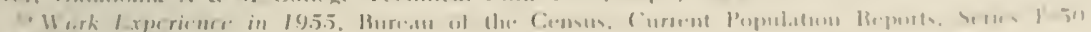
So. 6.5. $\mathrm{Fi} 1$.., 19.56.

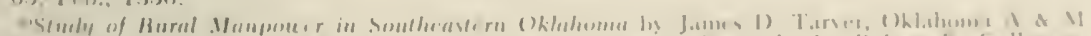

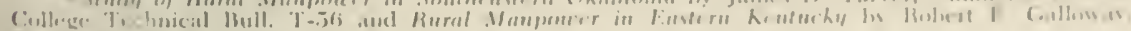
kevtuchy Agr. lexp. Sta. Bull. 6i27. 


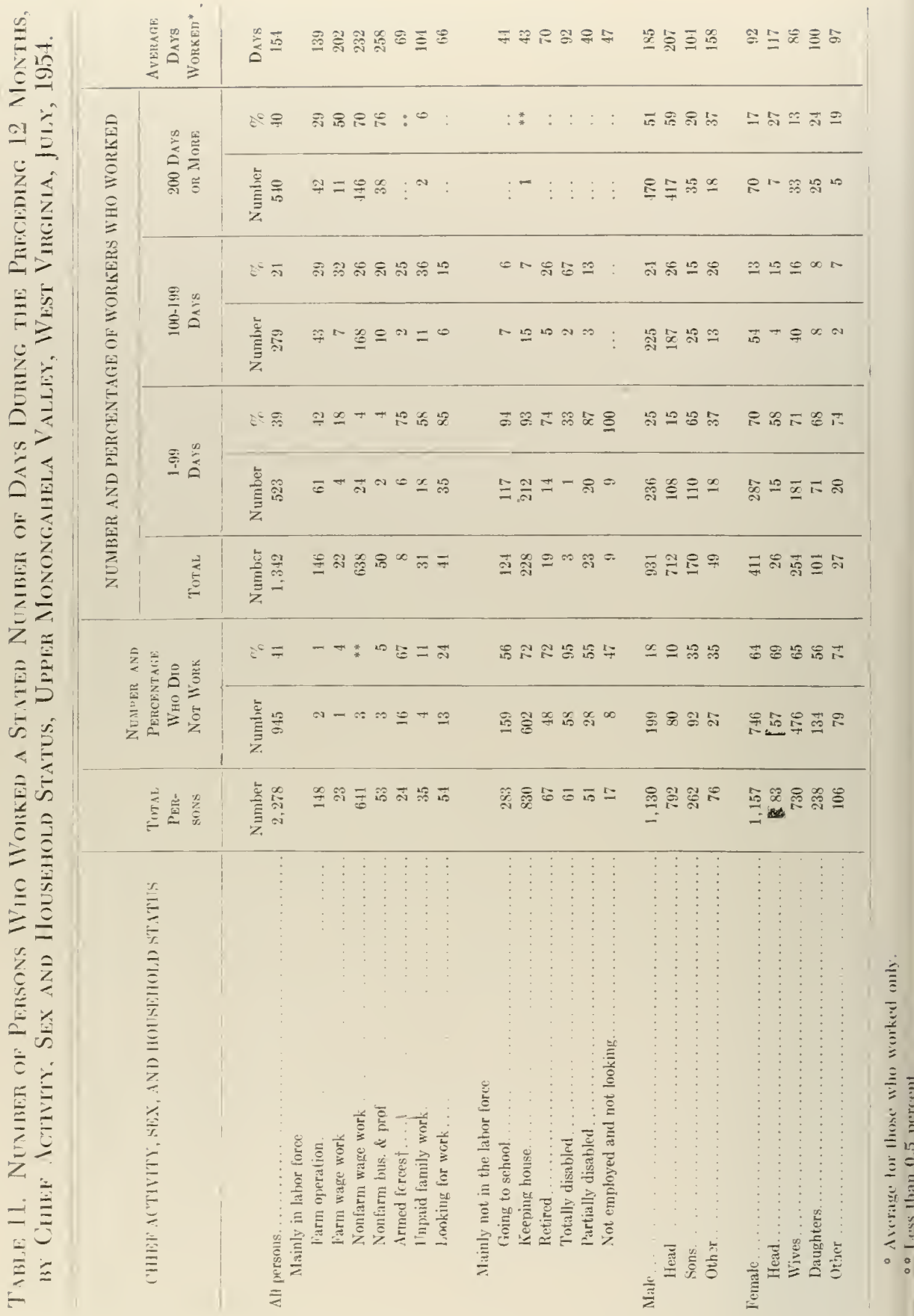




\section{Percentage in labor force who had no remunerative work during the last 12 months.}

\section{Upper \\ Monon- gahela Valley}

All persons over 14 Male

Female
41

18

64
South-

Eastern eastern Kentucky Oklahoma 43

48

20

79
United

States

37

14

51

'11 percent of male heads of households had done no work.

Nonworkers included 10 percent of the heads of households, onethird of the other males in the households, and two-thirds of the females. thost two-thirds of the nonworkers reported keeping house as their major activity during the year, 17 pereent more were school youth, and 14 percent were retired or disabled people. Of the 34 other people in the survey group who had done no work during the previous 12 months, 16 had been in the armed forces for at least part of the year.

Forty-one percent of the people 14 years old and over had engaged in no remunerative employment during the year, and an additional 2:3 percent of them had worked for less than 100 days. Only one-third of the people 14 years old and over worked for as many as 100 days.

The small amount of employment of women is significant. Twothirds of the women over 14 dicl no remunerative work during the rear; an additional 25 percent worked for less than 100 days. Only 11 percent worked for 100 days or more during the year. These data indicate that there are relatively few employment outlets for women in the area.

The people who worked had an average of $15 t$ days of work during the preceding year. Males averaged 18.5 days, and females, 92. The outstanding difference, other than that on the basis of sex, was between farm and non-farm workers. Farm workers worked for an average of only 13.9 days, ${ }^{21}$ and nonfarm wage workers averaged 2:32 days, and persons engaged in business or professional work 255 days. It is significant that people who were primarily farm-wage workers averaged considerably more employment than those who were manly farm opterators. $^{22}$

Unpaid family workers averaged 104 days of work. Is in the calse of farm-wage workers, this group does not include persoms whose chitel

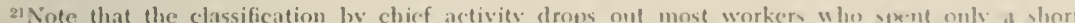
perind of time at a particular line of work. Ifence only 148 of the 316 f.irm ipuraters are repurtert

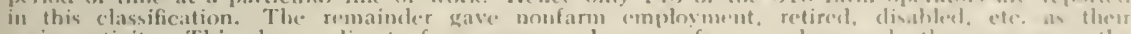

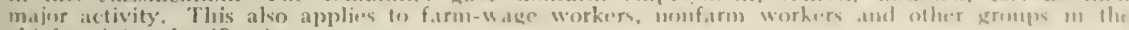
thicf aclivity classification.

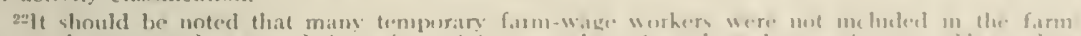

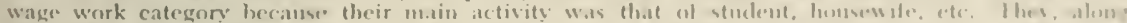

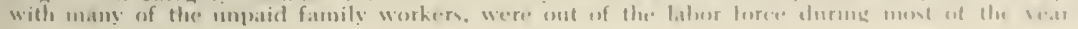


activity was attending school, keeping house, retirement, or disability. Housewives and school youth averaged about 44 days of work, or about the time needed to help during the rush season on the farm. Disabled and retired people reported averages from $2 S$ to 58 days, depending on their state of disability.

It is interesting that 41 percent of the male heads of households had less than 200 days of employment. These people ordinarily were breadwinners, and 200 days represent about the minimum length of employment that such a person can have and still fulfill his responsibilities to his family. In general, however, short-time workers were largely secondary workers in these households.

\section{LENGTH OF EMPLOYMENT AS RELATED TO TYPE OF WORK AND TYPE OF WORKER}

The persons who did some work during the previous 12 months were classified occupationally in two ways: (1) by their various combinations of farm and nonfarm work, and (2) by the particular industry or occupation at which they worked for the longest time. Total number of persons reported on the two classifications vary slightly because of a few of the workers had so little or such varied employment as not to be classifiable by industry. These were dropped from the industrial classification.

Persons who worked on the home farm only were least well employed (Table 12). They averaged 58 days of work during the preceding 12 months. Two-thirds of them worked for less than 50 days-only $\$$ percent worked more than 150 days. As will be shown in a subsequent table, the number of days worked was small largely because of the age and sex composition of this group of workers.

Employment at farm-wage work, when examined in terms of all farm-wage workers irrespective of their major activity, proves to be ciuite irregular. Those persons who did farm-wage work only had an average of 99 days of work during the year, and only one-fourth of them worked for more than 150 days.

Workers who combined work on the home farm with farm-wange work were also underemployed. They worked for an average of only 120 days. Only one-third of them worked for more than 150 days. Apparently these people were only marginal farm workers and did not have steady employment even with the additional work they obtained on other farms.

The length and regularity of employment varied markedly for nonfarm employment. Workers who engaged in nonfarm work only had an average of 195 days of work during the year. Those who combined farm operation with nonfarm employment averaged 232 days. And those who 
Table 12. Days Worked During the Previous 12 Moxthis as Relatild TO THE TYPE OF WORK DONE BY WORKERS IN UPPER WONONGAHELA

Valley, West Virginia, Julx; 1954.

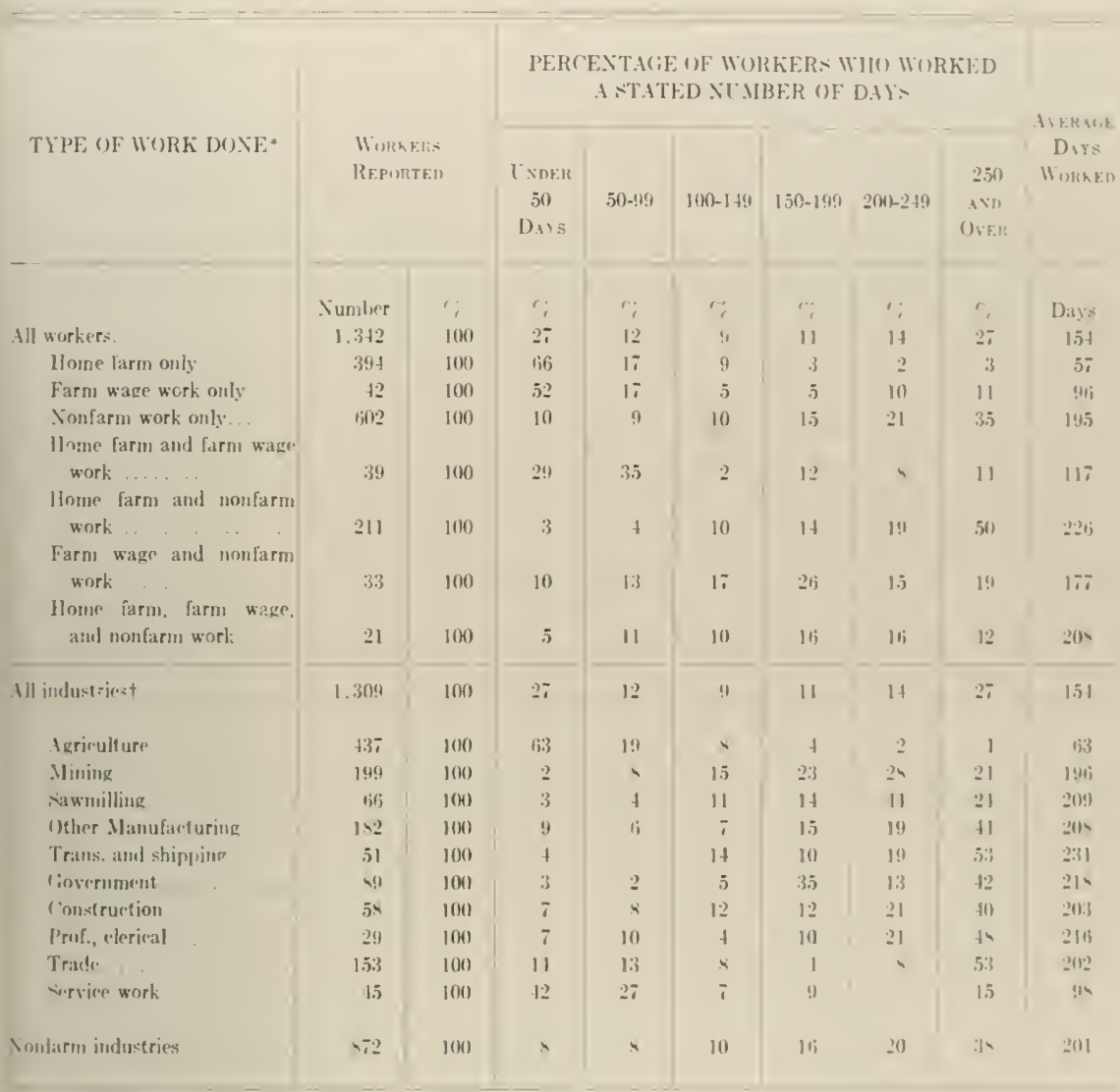

- During the 12 months proceding the interview.

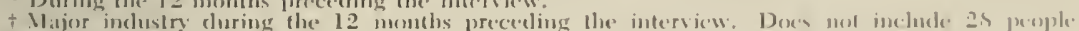

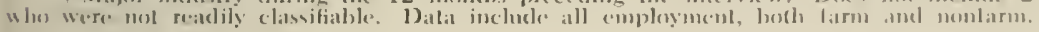

combined farm operation with nonfarm work and in addition did some farm-wage work areraged 214 days. From onc-half to owere two-thirds of the people in these three groups worked for 200 ding or more. Shortterm workers were not mumerous in this group. Only 10 perecut worked for less than 50 days and 29 pereent for less than 1.50 diens.

llorkers who combined nonfarm comployment with latrm-wage worh ordinarily did not fare as well. They aroraged ouly $17 \mathrm{~S}$ dass of emplos-

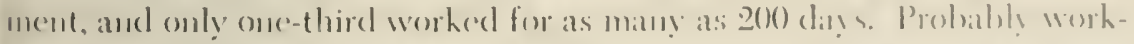
(res who combine farm-wige work with nonfarm employ ment are a mene marginal group than thesse whe can sperod foll tince at montam work. 
Furthermore, seasonal farm-wage work and nonfarm employment do not alway's dovetail smoothly.

When workers are classified by the industry at which they worked longest during the previous 12 months, the smaller amount of employment of those who engaged chiefly in agriculture stands out prominently: Such workers averaged only 63 days of work as compared to 200 for miners and an even larger number of days for other types of nonfarm workers. Only the service workers, with an average of 101 days, can be compared with people in agriculture. Yet the employment of these workers, largely women who worked at unskilled jobs on an irregular basis, was much greater than that of the farm workers.

It should be noted that these data are for total days of employment and do not necessarily mean, for example, that miners worked 200 days at mining. Some did a little subsistence farming on the side, others may have engaged in more than one type of nonfarm work.

\section{EMPLOYMENT ON THE HOME FARM}

There were 665 people who did some work on their home farms. Of these, 394 did no other work. The remainder either engaged in nonfarm work or were employed on other farms, or both. As inclicated in Table 13. it was those people who had worked on the home farm only who had the shortest period of employment, 58 days, during the previous year.

The greater frequency of short-term employment among workers in agriculture was partly due to the larger proportion of the workers on farms who were women, children, or old persons. The higher proportion can be presented as follows:

Percentage of workers who were women

Percentage of workers who were vouth $-14-24$ yrs. old

Percentage of workers who were aged-6.5 yrs. old and over

Percentage of workers who were able-bodied adults -24 to 64 yrs. old

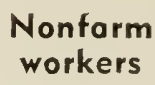

19

15

4

S1

67

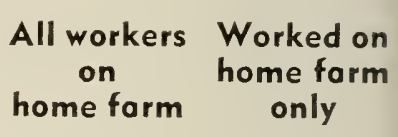

39

60

20

21

16

24

64

60

Percentage of workers who were

able-bodied males-(adult)

24 to 64 yrs. old

Yet this factor accounts for only part of the difference. Adult male workers on farms worked substantially less than those who were employed 
Table 13. Days of Work ox the HoNe Faril by (1) Tirose Who Worked ox the Fariy ONly, axd (2) All Persoxs Who Did Sonfe IVork ox the Hoire Fari, bY Age ANo Sex, Upper MoxoNgahela Valley, West Virgixia, July, 1954.

\begin{tabular}{|c|c|c|c|c|c|c|c|}
\hline \multirow{2}{*}{ AGF AID SEX } & \multirow[b]{2}{*}{ 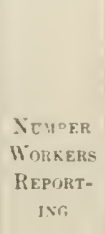 } & \multicolumn{5}{|c|}{$\begin{array}{c}\text { PERCENTAGE OF WORKERS WHO WORKED } \\
\text { A STATED NLMBER OF DAY'S }\end{array}$} & \multirow[b]{2}{*}{$\begin{array}{l}\text { A. ERARE } \\
\text { OH BEE } \\
\text { OF DAYA } \\
\text { WISRE }\end{array}$} \\
\hline & & [xner 50 & $50-99$ & $100-149$ & $150-199$ & $\begin{array}{c}201 \\
A \times n \quad O: E R\end{array}$ & \\
\hline Worked on home farm only. & $\begin{array}{l}\text { Worker: } \\
394\end{array}$ & $\begin{array}{l}\text { Pereent } \\
\quad 66\end{array}$ & $\begin{array}{c}\text { Perient } \\
17\end{array}$ & $\begin{array}{c}\text { Percent } \\
9\end{array}$ & $\begin{array}{c}\text { Pereent } \\
3\end{array}$ & $\begin{array}{c}\text { Percent } \\
5\end{array}$ & $\begin{array}{c}\text { Duys } \\
5\end{array}$ \\
\hline \multicolumn{8}{|l|}{ Male } \\
\hline $\begin{array}{l}1+24 \ldots \ldots \\
25-6+\ldots \ldots\end{array}$ & $\begin{array}{l}46 \\
+9\end{array}$ & in & 15 & 5 & 2 & & in \\
\hline 65 and over ......... & 63 & 34 & 32 & $\begin{array}{l}29 \\
14\end{array}$ & $\begin{array}{r}12 \\
8\end{array}$ & $\frac{23}{2}$ & $\begin{array}{r}130 \\
-5\end{array}$ \\
\hline \multicolumn{8}{|l|}{ Female } \\
\hline $14-24 \ldots \ldots$ & 36 & 92 & \& & & . & & 29 \\
\hline $25-6+\ldots \ldots$ & 167 & $\because 9$ & 14 & 5 & 1 & 1 & 30 \\
\hline 65 and over .. & 33 & 76 & 21 & 3 & & . & 39 \\
\hline All workens on home farm & 665 & 62 & 20 & 10 & 4 & + & $61^{\circ}$ \\
\hline \multicolumn{8}{|l|}{ Male } \\
\hline $14-24 \ldots \ldots \ldots \ldots$ & 91 & 79 & 13 & 5 & 2 & 1 & +2 \\
\hline $25-64 \ldots \ldots \ldots \ldots$ & 239 & 42 & 26 & 17 & 7 & s & .5 \\
\hline 65 and over........ & $i i$ & 34 & 31 & 14 & 6 & 11 & $\because$ \\
\hline \multicolumn{8}{|l|}{ Female } \\
\hline $14-24 \ldots \ldots \ldots$ & 40 & 90 & 10 & .. & .. & $\therefore$ & $3 n$ \\
\hline $25-64 \ldots \ldots \ldots \ldots$ & 186 & 79 & 14 & 5 & 1 & 1 & 40 \\
\hline 65 and over........ & 32 & 81 & 16 & 3 & .. & & $3 t$ \\
\hline
\end{tabular}

- Days of work on the home farm only.

in nonfarm occupations. The percentage of male workers 24 to 64 years old who had given amounts of employment are as follows:

\section{Days worked}

Under 100

$100-149$

$150-199$

200 and over

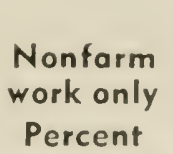

13

13

16

5S

\section{Work on home farm only Percent}

36

29

12

$1: 3$

The average number of days worked by the nonfarm males 25 to fit years (okl was 20.5, whereas those who worked only on the heme farme weraged 130. This comstitutes an at erage difference of 7.5 days or almont is munthe 
per worker. A comparison can be made for the other age and ses groups in terms of average days worked as follows:

Males $14-24$ years old

Males 25-64 years old

Males 65 and over

Females $14-24$ years old

Females 25-64 years old

Females 65 years old or over
Average number of days

Work on home farm only

40

130

8.5

29

39

39
Nonfarm work only

136

205

145

146

178

42

\section{FARM-WAGE WORK}

Farm-wage work was a relatively unimportant source of employment in this area. It served as a supplementary source of income, but cnly a few people reported it as their major type of work. A total of 134 people had done some farm work for wages during the previous year, but of those, only 42 gave it as their sole employment (Table 14). Half of the 42 persons were less than 25 years old. Evidently young people use farmwage work as a stepping stone to other types of employment.

In terms of length of employment, farm-wage workers were of two distinct types. Two-thirds were short-term or seasonal workers who worked for 50 days or less. Another group were regular farm workers who were employed for 150 days or longer. A few of these worked on dairy or livestock farms and had continuous employment during the year.

\section{NONFARM EMPLOYMENT}

Of the 877 persons who engaged in nonfarm employment. almost 70 percent clid no agricultural work either on the home place or as hired farm workers. Most of the remainder did some work on the home place, and a few engaged in hired farm employment for part of the year. Although the amount of farm work done by these people was not large, it served as a significant supplement to their other employment. It increased the total average days of employment for the nonfarm workers by 15 days, from 186 to 201 . Attention will first be given to the number of days of nonfarm work, then to total days of work by the same group of workers.

As indicated in the discussion on work on the home farm. the nonfarm workers were largely adult males. The adult males averaged 202 days of nonform work, but 26 percent of them worked for less than 150 days (Table 15). Workers under 2.5 years of age and over 64 were much more irregular in their employment. More than half of them worked for less than 150 days. 


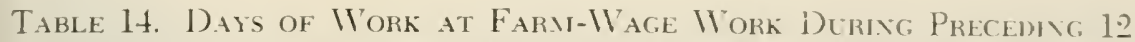

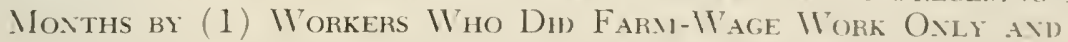

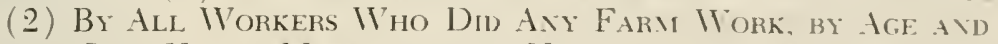
Sex, Upper Moxoygahela V'alley, West Virginia, JULY, $19 \overline{\mathrm{t}} \mathrm{t}$.

\begin{tabular}{|c|c|c|c|c|c|c|c|c|}
\hline \multirow{2}{*}{ AFIF AND $\triangle E X X$} & \multirow{2}{*}{$\begin{array}{c}\text { NHTOEK } \\
\text { WORAERS } \\
\text { REPIHT- } \\
\text { ING }\end{array}$} & \multicolumn{6}{|c|}{ 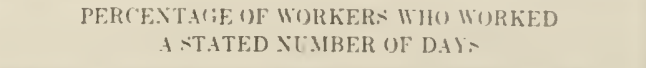 } & \multirow{2}{*}{ 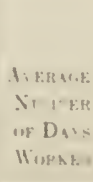 } \\
\hline & & $\begin{array}{l}\text { VNDEH } \\
50\end{array}$ & $50-99$ & $100-119$ & $15(1)-199$ & $261-24 !$ & $\begin{array}{l}250 \\
\operatorname{AND}(), \mathrm{A}: P\end{array}$ & \\
\hline & Workers & $\because$ & $\because$ & $\because$ & $\because$ & $\ddots$ & $\therefore$ & Davs \\
\hline $\begin{array}{l}\text { Workers who did farm } \\
\text { wage work only }\end{array}$ & 42 & 50 & 19 & 5 & $j$ & 12 & 9 & \\
\hline \multicolumn{9}{|l|}{ Mrale } \\
\hline $14-24$ & 20 & 5.5 & 35 & 10 & & & & ifi \\
\hline $25-6.1$ & 14 & 29 & $i$ & . & 14 & 24 & 21 & 184 \\
\hline tj.5 and over & 4 & 50 & . & . & & 25 & 25 & $13 ! !$ \\
\hline Fenale & 4 & 100 & . & & & & & 21 \\
\hline All farm wage workers & 134 & fif & 13 & fi & 5 & 4 & 6 & tis? \\
\hline \multicolumn{9}{|l|}{ Male } \\
\hline $\mid 1-21$ & 55 & $7: 3$ & 15 & 5 & 4 & & & 45 \\
\hline $25-64, \ldots \ldots$ & 63 & 57 & 11 & s & $s$ & ; & 9 & (11) \\
\hline 6,5 and over... & 11 & 33 & .. & & 1 & 4 & in & 43 \\
\hline Fenale. & 5 & 100 & . & . & . & & .. & 25 \\
\hline
\end{tabular}

Only 42 percent of the miners and only 40 pereent of those employed by public agencies worked for 200 days or more. In contrast, oser twothirds of the workers in transportation and shipping and in professional. technical, and clerical work were employed for 200 days or more.

Probably it is total employment of these workers rather than merely their nomfam work that is important. At least it will provide a better picture of underemployment. The adelitional amount of amployment afforded by fam work varied from one industry to another. The alrerace momber of days added was as follows:

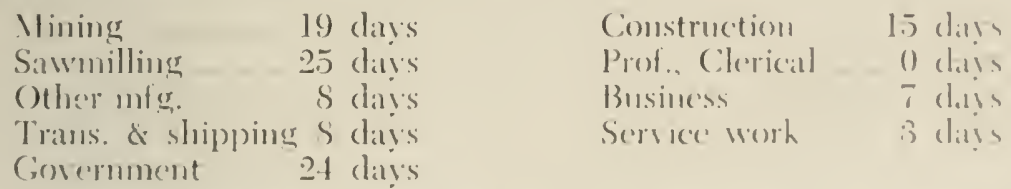

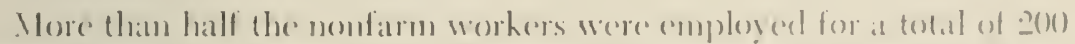

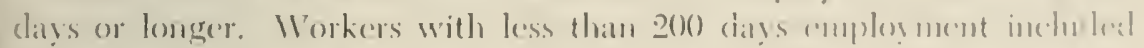

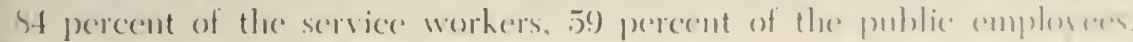


Table 15. Length of Employanent at Nonfara Work During the Precedng 12 Months, by Age, Sex, and Industry, Upper

Moxongahela Vallex, West Virginia, July, 1954.

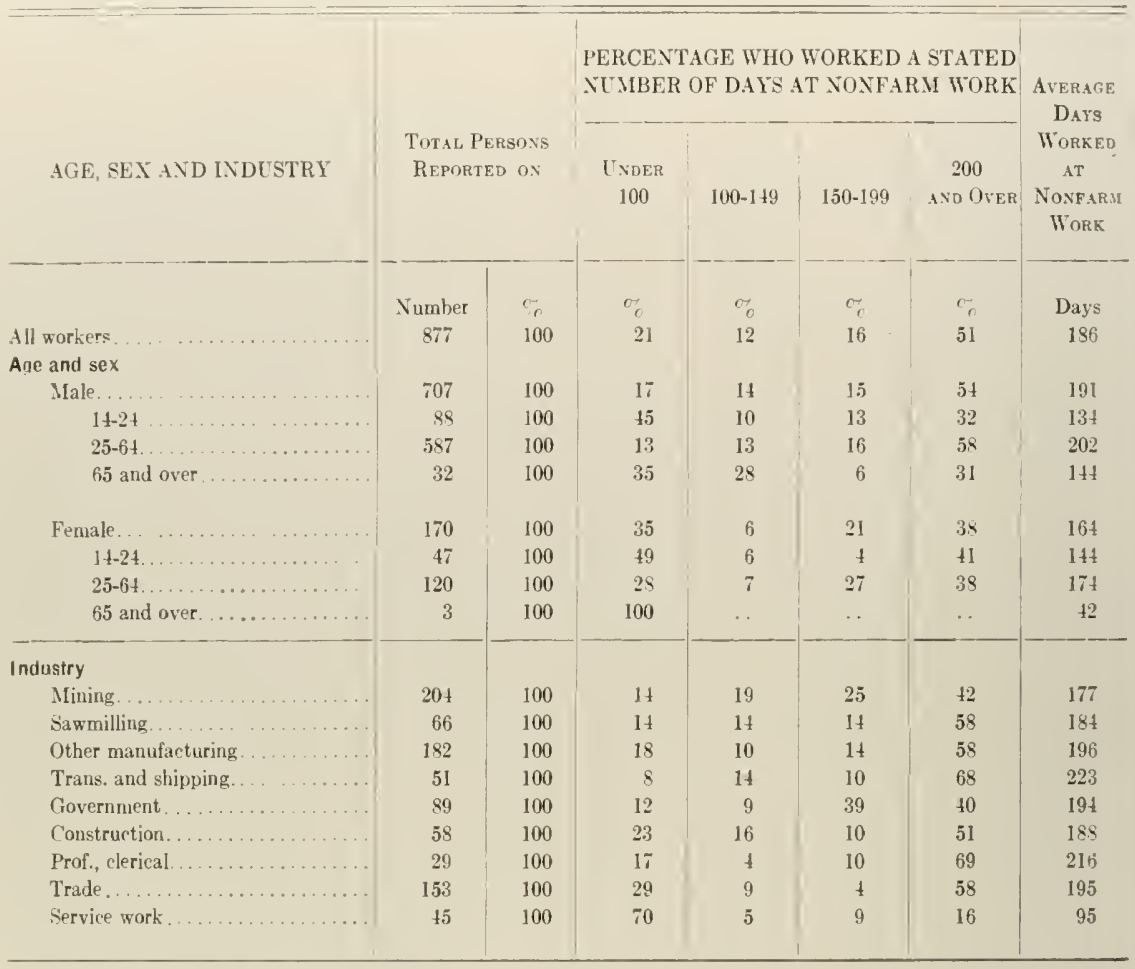

and 58 percent of the miners (Table 16). It included less than one-third of the workers in transportation and shipping, and professional, technical, and clerical work.

Thirty-eight of the 45 people who engaged in service work had less than 200 days of work. They were largely women, and only one-fifth were heads of households. Yet their work was so irregular as to suggest that there was considerable underemployment among them.

For employees in mines the evidence of underemployment is more positive. Among the 96 workers who were employed for less than 200 days, 82 were heads of households. Half of these had worked for less than 150 days. Employment in other types of industry besides mining was also somewhat irregular but did not affect quite as high a proportion of heads of households. 
Table 16. Numiber of Noxfariy Workens wtth Linteid Eyployient During the Preceding 12 Mo:the, by INdestry aid Houseulold Status, Upper Monoxgahela V'alley, West V'irginia, July, 19.5̆.

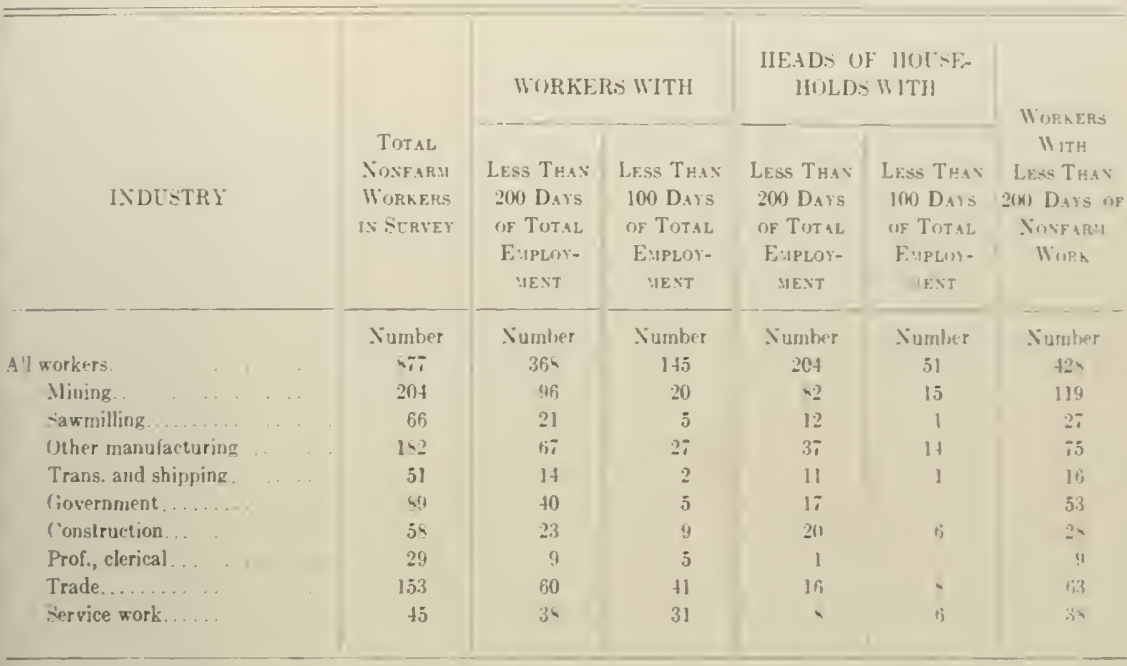

\section{Incomes of Households and of Workers in the Valley}

Although incomes of the open-country people in the Upper Ifonongahela Valley were modest, they cane from a wide varicty of sources. In the typical household the major source of income was the eaminess of the head of the household from nonfarm cmployment. In abont methird of the households a second nonfarm worker also added to the family revenue. About half the houscholds supplemented their incomes by some agricultural production. 2.3 These activities usually were the production of milk, eggs, and vegetables for home consumption. A majority of the households had income from nonwork sourees. ${ }^{24}$ Fre(quently this was in the form of rents, or royalties or other returms from coal mining, but expally common were payments from social secority. unemployment insurance, retirement funds, or some other type of gremp) bencfit. Only a few househelds had income from hired farm work.

The income situation of houselosels cougaged in agriculture on al commercial basis diel not vary greatly from the foregeneng patterm. ()nls

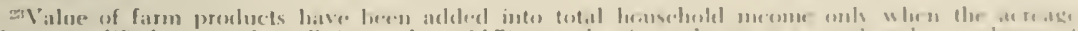

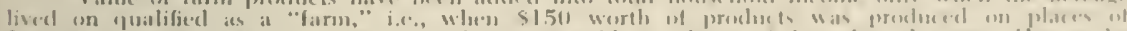

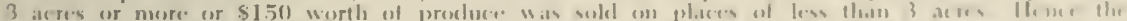

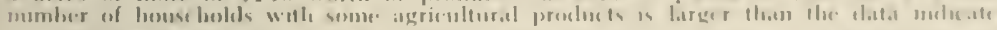

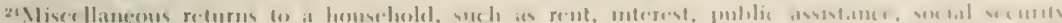

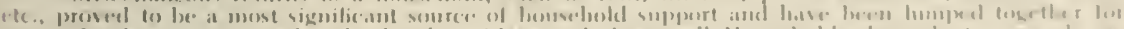

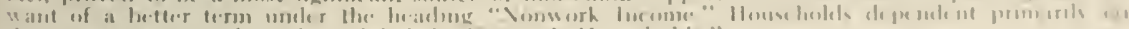

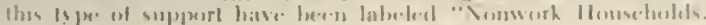


4 () of the 73 commercial farm households depended on farming alone. The rest. along with the 226 houscholds on part-time and residential farms, had incomes from nonfarm sources.

The households were classified by chief source of income, and only 75 , or 8.6 percent, received more income from agriculture than from other sources. A total of 170 households, or 19 percent. had mining as their chief source, and another 19 percent, manufacturing (Table 17). Over 20 percent received their major income from nonwork sources.

Of the households with farming as their chief sources of income, approximately two-thirds had total incomes of less than $\$ 1,000$. Only 12 of the 75 households of this type had incomes of over $\$ 2,000$.

A rather comparable situation existed among the nonwork households. More than half of them had incomes of less than $\$ 1,000$. Only 30 of the 178 households of this type had incomes of over $\$ 2,000$.

Households in these two groups-farming and nonwork-account for most of the low income households in the area ( 151 out of 201 households with incomes under $\$ 1,000)$. A total of 10 mining, 9 manufacturing, and 3 business households, and $2 S$ households with incomes from miscellaneous sources were also in the under-\$1,000 group.

Only 93, or 11 percent, of the households had incomes of more than $\$ 5,000$. All but 5 of these households had their chief source of income from nonfarm work.

The aggregate income of the $\$ 75$ sample households in the Valley during the preceding 12 months amounted to somewhat more than $\$ 2,000,000$. It can be subdivided between major sources as follows:

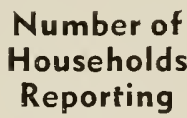

Home farm income

Farm wage work

Nonfarm work

Nonwork sources

All households
313

109

656

505
Average per
Household
Reporting

$\$ 290$

312

2,878

656
Average For All Households $\$ 100$ 39 $2,15 \mathrm{~S}$ $37 \mathrm{~S}$ 2,675

Income from agriculture, including both work on the home farm and that received in the form of wages for labor, amounted to less than 6 percent of the total. Income from operation of the home farm alone amounted to shightly more than 4 percent. These small percentages are partially due to a poor crop year in 1953 when yields were cut down by a shortage of rainfall. Surprisingly, income from nonwork sources, 14 percent of the total, was much greater than that from agricultural sources.

The fact that these people received 94 percent of their incomes from nonfarm sources indicates their great dependence on industrial prosperity. 


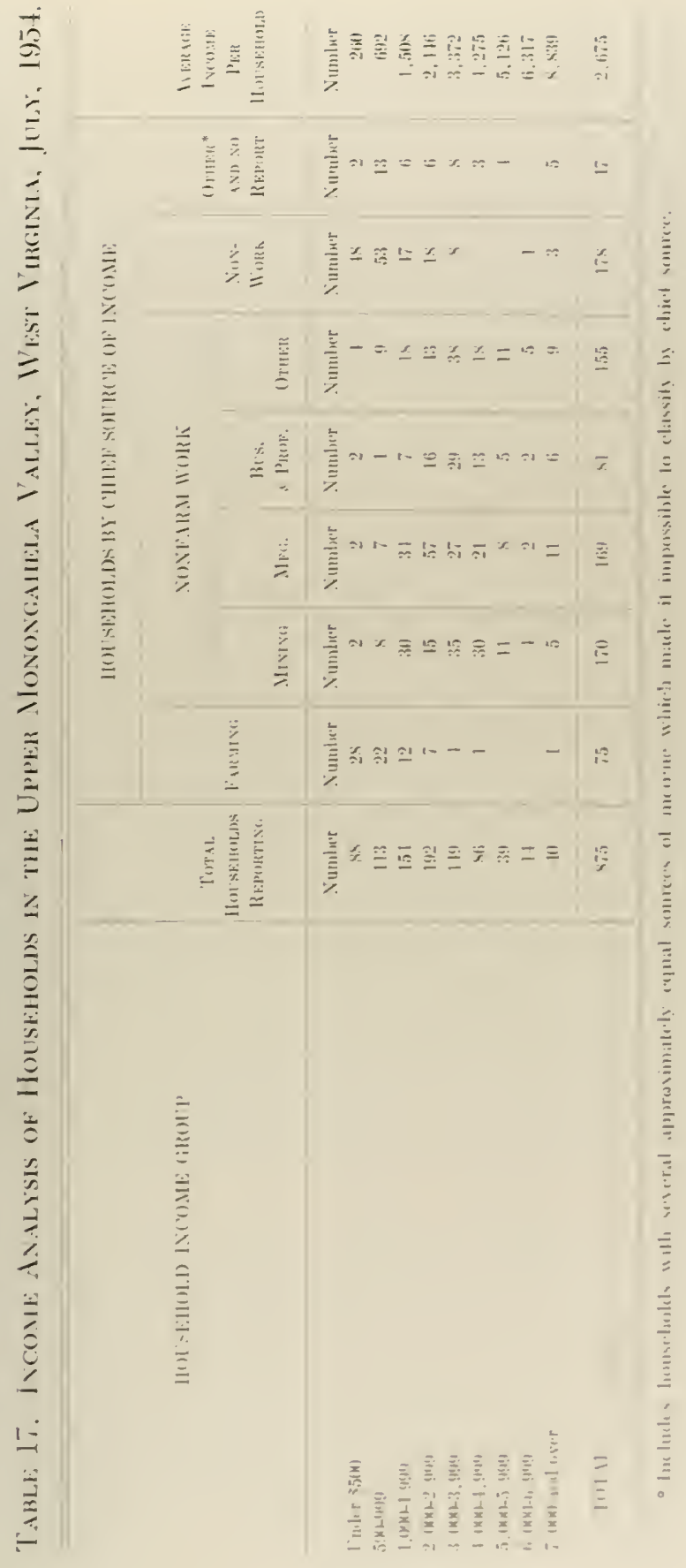


Agriculture serves as an income supplement and helps to reduce living costs, but for most families it does not provide a major cushion against industrial adversity. Unemployment benefits, royalties, interest, social security payments, and other types of nonwork income provide the greatest assistance in the event of loss of jobs or other industrial mishaps.

Income from nonwork sources is second in importance to income from nonfarm wages and salaries. The number of households drawing the major types of nonwork income is shown in Table 18. The figures indicate that about half of the farm operator families received either rent, royalties, or interest payments. Ordinarily they were not recipients of social security, memployment insurance, retirement or other types of public or group payments. Royalty payments to farmers by mining companies that had leased their mineral rights were quite common but usually were small.

The extent to which the incomes of mining, manufacturing. and other non-farm households, except the business and professional. were buttressed by unemployment insurance benefits is most significant. Almost one-third ( 31 percent) of the miners' households and 28 percent of those of workers engaged in manufacturing had received this type of income supplement. Many of these households also received income from social security. workmen's compensation, and retirement funds.

Households in which nonwork incomes were the largest source of funds frequently received more than one type of nonwork income; 27T different sources were reported for 178 households in this group. Social security payments or retirement funds were mentioned most frequently. Approximately one-third of these households reported receiving income from either one or the other. A somewhat smaller proportion received funds from state relief or from interest payments.

Nonwork income served in many households as a supplement to other sources of revenue. Nonwork incomes, however, were usually low, and were responsible along with agriculture for the low level of incomes in the Valley.

A comparison of the households in regard to type of farm and sources of income provides a more exact idea of which households are in a marginal economic position. In such a comparison, residents on commercial farms slow up largely in the under $\$ 1,000$ and $\$ 1,000-2,000$ income groups (Table 19). Households on part-time farms were in a much better position, due largely to their earnings from nonfarm sources. ${ }^{25}$ Two-thirds of them were in the group receiving from $\$ 1,000$ to $\$ 4,000$. Nost of the other third received over $\$ 4,000$. Households on residential farms were

The classification into commercial, part-time, and residential farms is that used in the 19.50 Censur. For a definition of each type see Appendix. 


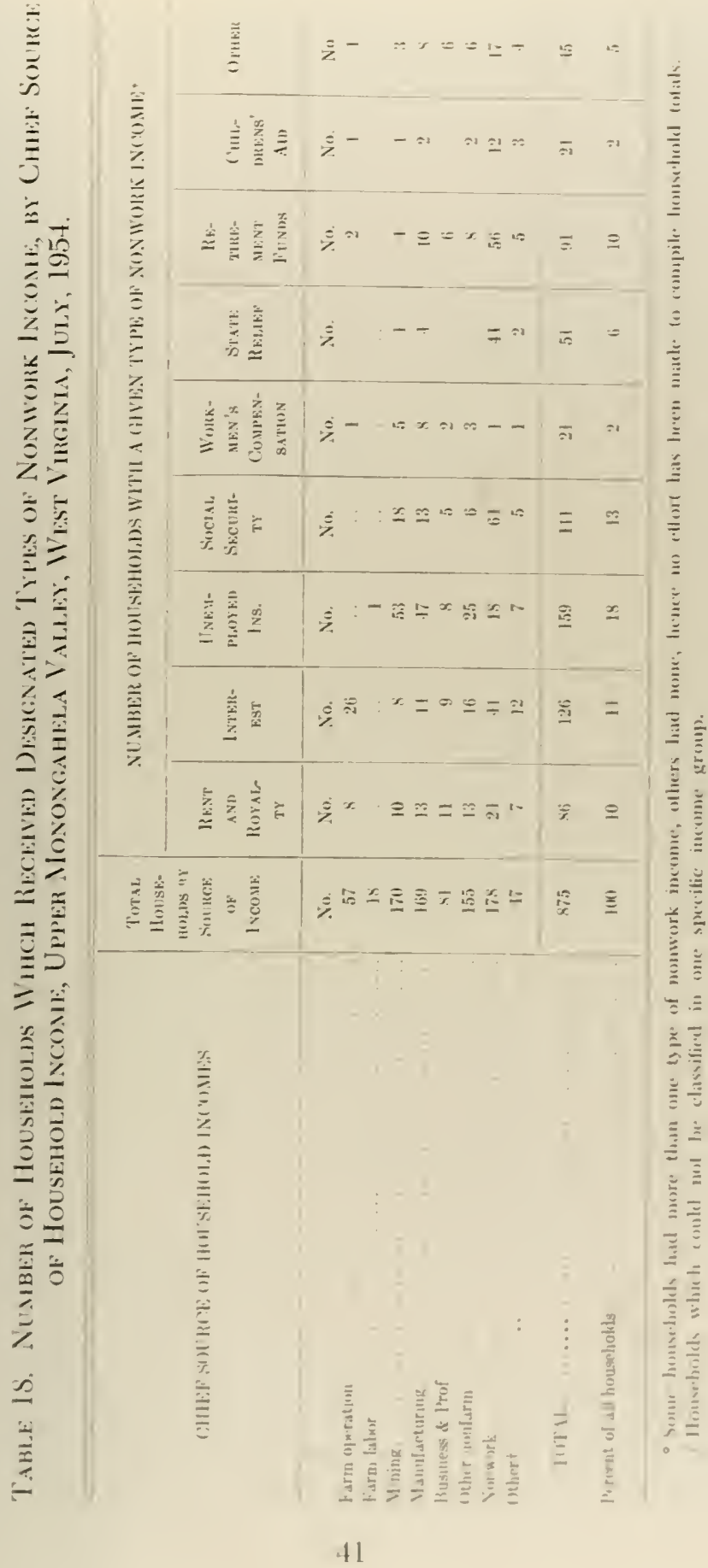


Table 19: Percentage of Households With Ixcomes of Stated Amounts, by Residence, Income Source, Industry Group, and Level of Living, Upper Monongahela Valley, IVest V'irginia, JuLY, 1954.

\begin{tabular}{|c|c|c|c|c|c|c|c|c|c|c|}
\hline \multirow[b]{2}{*}{ TYPE OF HOUSEHOLD } & \multirow{2}{*}{\multicolumn{2}{|c|}{$\begin{array}{c}\text { Total } \\
\text { Hocseholds } \\
\text { RePORTiNG }\end{array}$}} & \multicolumn{8}{|c|}{ PERCENTAGE OF HOLSEHOLDS WITH INCOME } \\
\hline & & & $\begin{array}{l}\text { ITDER } \\
\$ 1,000\end{array}$ & $\begin{array}{l}1,000 \\
1,999\end{array}$ & $\begin{array}{c}2,000- \\
2,999\end{array}$ & $\begin{array}{c}3,000- \\
3,999\end{array}$ & $\begin{array}{l}4,000- \\
4,999\end{array}$ & $\begin{array}{c}5,000- \\
5,999\end{array}$ & $\begin{array}{l}6,000- \\
6,999\end{array}$ & $\begin{array}{l}7,000 \\
\text { \& Over }\end{array}$ \\
\hline & Number & Pet. & $\sigma_{c}$ & $r_{c}$ & $\because$ & $\because$ & 7 & $\%$ & $r_{c}$ & $\because c$ \\
\hline All households. & & 100 & 22 & 19 & 21 & 17 & 10 & 6 & 4 & 2 \\
\hline \multicolumn{11}{|l|}{ By residence* } \\
\hline Nonfarm....... & 559 & 100 & 20 & 17 & 22 & 17 & 10 & 6 & 4 & 4 \\
\hline Farm......... & 299 & 100 & 24 & 19 & 21 & 16 & 10 & 6 & 4 & .. \\
\hline Commercial... & 73 & 100 & 45 & 19 & 15 & 6 & 6 & 4 & 5 & . \\
\hline Part-time.... & 68 & 100 & 6 & 26 & 18 & 21 & 10 & 10 & 9 & .. \\
\hline Residential... & 158 & 100 & 24 & 16 & 25 & is & 11 & 5 & 1 & .. \\
\hline \multicolumn{11}{|l|}{ By income type** } \\
\hline Agriculture only..... & 40 & 100 & 77 & 8 & $s$ & 5 & 2 & . & & . \\
\hline Xonfarm work only. & 355 & 100 & 6 & 12 & 27 & 27 & 15 & 9 & 1 & .. \\
\hline Nonwork only ...... & 123 & 100 & 68 & 22 & 7 & 2 & .. & 1 & .. & . \\
\hline $\begin{array}{l}\text { Agriculture nontarm } \\
\text { work }\end{array}$ & & & & & & & & & & \\
\hline Mainly agriculture .... & 35 & 100 & 54 & 26 & 11 & 6 & & . & 3 & .. \\
\hline Mainly nonfarm work... & 81 & 100 & 19 & 37 & 21 & 10 & 7 & 2 & 4 & .. \\
\hline Nonfarm work-non-work & & & & & & & & & & \\
\hline Mainly nonfarm work... & 174 & 100 & 7 & 16 & 30 & 16 & 13 & 8 & 10 & .. \\
\hline Mainly non work. ...... & 29 & 100 & 28 & 38 & 17 & 10 & .. & . & 7 & $\cdots$ \\
\hline Other $\uparrow \ldots \ldots \ldots \ldots$ & $3 s$ & 100 & 5 & 8 & 3 & 13 & 13 & . & .. & 58 \\
\hline \multicolumn{11}{|l|}{ By chief income scurce } \\
\hline Agriculture......... & 75 & 100 & 68 & 15 & 10 & 5 & . & $\ldots$ & 2 & .. \\
\hline Mining............ & 170 & 100 & 6 & 18 & 26 & 20 & 14 & 9 & 3 & . \\
\hline Manufacturing. . & 169 & 100 & 5 & 20 & 34 & 16 & 12 & 6 & 7 & . \\
\hline Business \& prof . ....... & $\$ 1$ & 100 & 3 & 9 & 20 & 36 & 16 & 9 & $i$ & .. \\
\hline Other nonfarm work.... & 155 & 100 & 8 & 12 & 28 & 24 & 12 & 10 & 6 & .. \\
\hline Nonwork........... & 178 & 100 & 57 & 26 & 10 & 4 & . & 1 & 2 & \\
\hline Other $\dagger$............ & 47 & 100 & 10 & 15 & 2 & 11 & 11 & 2 & 2 & 47 \\
\hline \multicolumn{11}{|l|}{ By level of living $\dagger^{\prime} \dagger$} \\
\hline High......... & 275 & 100 & 6 & 11 & 19 & 22 & 17 & 12 & 10 & 3 \\
\hline Medium.......... & 344 & 100 & 21 & 18 & 24 & 20 & 9 & 5 & 2 & 1 \\
\hline Low . . . . . . . . . . & 256 & 100 & 40 & 24 & 20 & ; & 3 & 1 & 1 & 4 \\
\hline
\end{tabular}

- 17 households not reported on by residence. For definition of the various types of farms see Appendix.

As between tarm, nonfarm, and nonwork sources.

$\div$ Income from 2 or more almost-equal sources.

$\div$ See page 23 for discussion of level of living.

in an intermediate position; 40 percent had incomes of less than $\$ 2,000$; another 40 percent had incomes of $\$ 2,000$ to $\$ 4.000$.

If the households are divided into three major groups according to source of income, close association between agriculture and low income becomes quite evident. Three-fourths of the households that relied entirely on farming for a livelihood had incomes of less than $\$ 1.000$. By comparison. only 6 percent of the households that depended on nonfarm 
work had incomes of less than $\$ 1,000 ; 70$ percent had incomes from $\$ 2,000$ to $\$ 5,000$. Nonwork households were in an income position similar to that of farm households. ${ }^{26}$. Households with incomes partly from farming and partly from nonfarm sources were not as well off as those who had income from nonfarm work only. It was members of households with modest farm or nonfarm incomes who most frecuently relied on income from both sources.

Incomes of miners' households ranged only slightly below those for nonfarm homes generally. Business and professional households had some income adiantage but their incomes were also quite modest. Yore than half of them were in the range of $\$ 2,000$ to $\$ 4.000$.

There was a high correlation between size of income and level of living. Two-thirds of the people with a low level of living had incomes of less than \$2.000 as compared to one-sixth of those with high levels of living. Level of living as measured in this survey was based on the possession of such items as electric lights, refrigerator, electric washing machine, automobile, and telephone. ${ }^{27}$

It has already been noted that marginal agricultural enterprises together with limited nonwork sources of income accounted for a large proportion of the low incomes among the households in the Valley. A related factor is that low-income households averaged consistently smaller in size and had fewer members with work incomes than those in a more fortunate financial position (Table 20). Households at the bottom of the income scale averaged only 2.3 persons and had only .3 persons witl, work income; that is, only 1 out of 3 had a person who had farm or nonfarm eamings. Those at the top averaged 5.1 persons and had an average of 2.2 breadwinners.

The comparison is not entirely perfect because all earuings in farm households were ascribed to the head of the houschold rather than being divided among all the members who did any farmwork. However, the low-income households were generatly so small that there were few potential workers in them. Many consisted only of 1 or 2 aged persons. Many of these people were subsisting entirely on retirement funds, social security payments, or similar income. On the other hand, some of the newly established households of two or three persons were also at the low end of the employment and incone scale.

\section{INDIVIDUAL EARNINGS}

It is diffiente to present incomess for all persons in the atreal ent an individual basis. Ineones of farm honseheolds might be div ieled between workers in the farm, houschold on the same basis that was used to allot

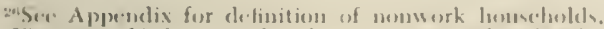

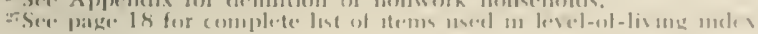


TAble 20. Size of Household and Number of WORKers per Household bY incone Groups, Upper Monongahela $Y_{\text {Alley, }}$

West Virginia, July, 1954.

\begin{tabular}{|c|c|c|c|c|}
\hline INCONE GROUP & $\begin{array}{l}\text { Hovse- } \\
\text { HoLDS } \\
\text { IN EACH } \\
\text { INCOME } \\
\text { GrotP }\end{array}$ & $\begin{array}{c}\text { PERCENT- } \\
\text { AGE } \\
\text { OF ALL } \\
\text { Hotse- } \\
\text { HOLDS }\end{array}$ & $\begin{array}{c}\text { Average } \\
\text { Persons } \\
\text { Per } \\
\text { Hodse- } \\
\text { hold }\end{array}$ & $\begin{array}{c}\text { AVERAGE } \\
\text { BREAD- } \\
\text { WINNERS } \\
\text { PER } \\
\text { Hotse- } \\
\text { HOLD }\end{array}$ \\
\hline & Number & Percent & Number & Number \\
\hline All households. & Si5 & 100 & 3.9 & 1.1 \\
\hline Up to $\$ 500$ & 88 & 10 & 2.3 & .3 \\
\hline $500-999 \ldots \ldots$ & 113 & 12 & 3.2 & .5 \\
\hline $1,000-1,999$. & 154 & 18 & 4.1 & 1.0 \\
\hline $2,000-2,999$ & 192 & 22 & 4.0 & 1.2 \\
\hline $3,000-3,999$. & 149 & 17 & 4.2 & 1.3 \\
\hline $4,000-4,999$ & 86 & 10 & 4.7 & 1.5 \\
\hline $5,000-5,999$. & 39 & 1 & 4.3 & 1.6 \\
\hline $6,000-6,999 \ldots$ & 14 & 2 & 4.1 & 1.6 \\
\hline 7,000 and cver. . . & 40 & 5 & 5.1 & 2.2 \\
\hline
\end{tabular}

the hours of work. However, this procedure would still not provide an accurate picture because income from nonwork sources was also obtained on a household rather than an individual basis, making two types of income that are not subject to division between individuals. Some broad averages can be presented. however, which will convey an impression of comparative individual earnings at farm and nonfarm employment. These are as follows:

$\begin{array}{lccc}\text { Wotal } & \begin{array}{c}\text { Average } \\ \text { persons }\end{array} & \begin{array}{c}\text { Average earn- } \\ \text { earnings }\end{array} & \begin{array}{c}\text { Angs per day } \\ \text { Work on home farm }\end{array} \\ \text { Farm wage work …… } & 131 & \$ 132 & \$ 2.25 \\ \text { Nonfarm work } & 855 & 2.206 & 4.21 \\ & & 2.206 & 11.85^{29}\end{array}$

This comparison is affected by the fact that two-thirds of the workers on the home farm were women, youth, or old people, as compared to only one-third of those in nonfarm employment. However, the difference in retums is so great that the tendency of workers to leave farming and go into nonfarm employment can easily be understood. The movement

${ }^{25}$ Total earnings from each type of work divided by total number of persons, paid and unpaid, who did any work of that type.

${ }^{29}$ These figures compare with 1954 data for West Virginia in regard to earnings of coal miners and other nonfarm workers as follows:

Eamings per hour Earnings per week Data from Annual Average Hours and Earnings of Production Workers in Manufacturing and in Conperation with U. S. Bureau of Labor Statistics.

Coal Mining
$\$ 2.51$
91.87

\section{Manufacturing $\$ 1.83$ 1.83
70.64}


would probably be even heavier if adequate opportunities for nonfarm employment were arailable.

Sex, age, and household status were important factors in the level of earnings of these people. Eamings of young men and of those over 65 were far below those of males in the more productive age group (Table 21 ). Nore than balf of them were in the group earning less than $\$ 1.000$, as compared to only 11 percent of the males 25 to 64 years old. More than half of the productive-age males were in the $\$ 2,000$ to $\$ 4,000$ income brackets and 20 percent more made over $\$ 4,000$. Age differences were even more important in the case of female workers; 60 percent of the roung women (under 24 ) were in the under-\$1,000 group as compared to 47 percent of the young men.

Differences in income on the basis of household status are also important. Two-thirds of the male heads of households earned more than $\$ 2,000$ as compared to 60 percent of the other adult males and only 25 percent of the sons. Very few male heads of households earned less than $\$ 1,000$, but more than 50 percent of the working sons did so. About half of the female workers had earnings of less than $\$ 1.000$. Surprisingly, female heads of households had lower eamings than the wives who worked. Twenty-eight percent of the wives earned more than $\$ 2,000$ as compared to only 12 percent of the female heads.

\section{Work Experience, 1946-1954}

Although the workers in the survey had their homes in the open county, 80 percent had done some nonfarm work during the preceding $S$ years. The experience of about half this group had been largely along industrial lines; for the others it was largely in business. govermment employment, or transportation and shipping. Most of these workers. therefore, differ from the hillside farmers who live in some menntainous rural areas. Yost of them are skilled or semiskilled workers with some proficiency along industrial lines.

All respondents were asked to indicate whether they or any members of their households had engaged in any nonfarm work hetwe'n 1916 and the date of the interview. For persons who had done such work. diatis were obtained on specific years of employment and the type of nonfirm work they had done for the longest time. A total of 1.049 persons reported some nonfarm work experience. In general, those engatged in nonfarm employment at the time of the interview were also those who had a latekground of nonfarm work. Approximately one-fiftle of these with nentfam experience were unemployed, disabled. or retired at the time of the interview. 


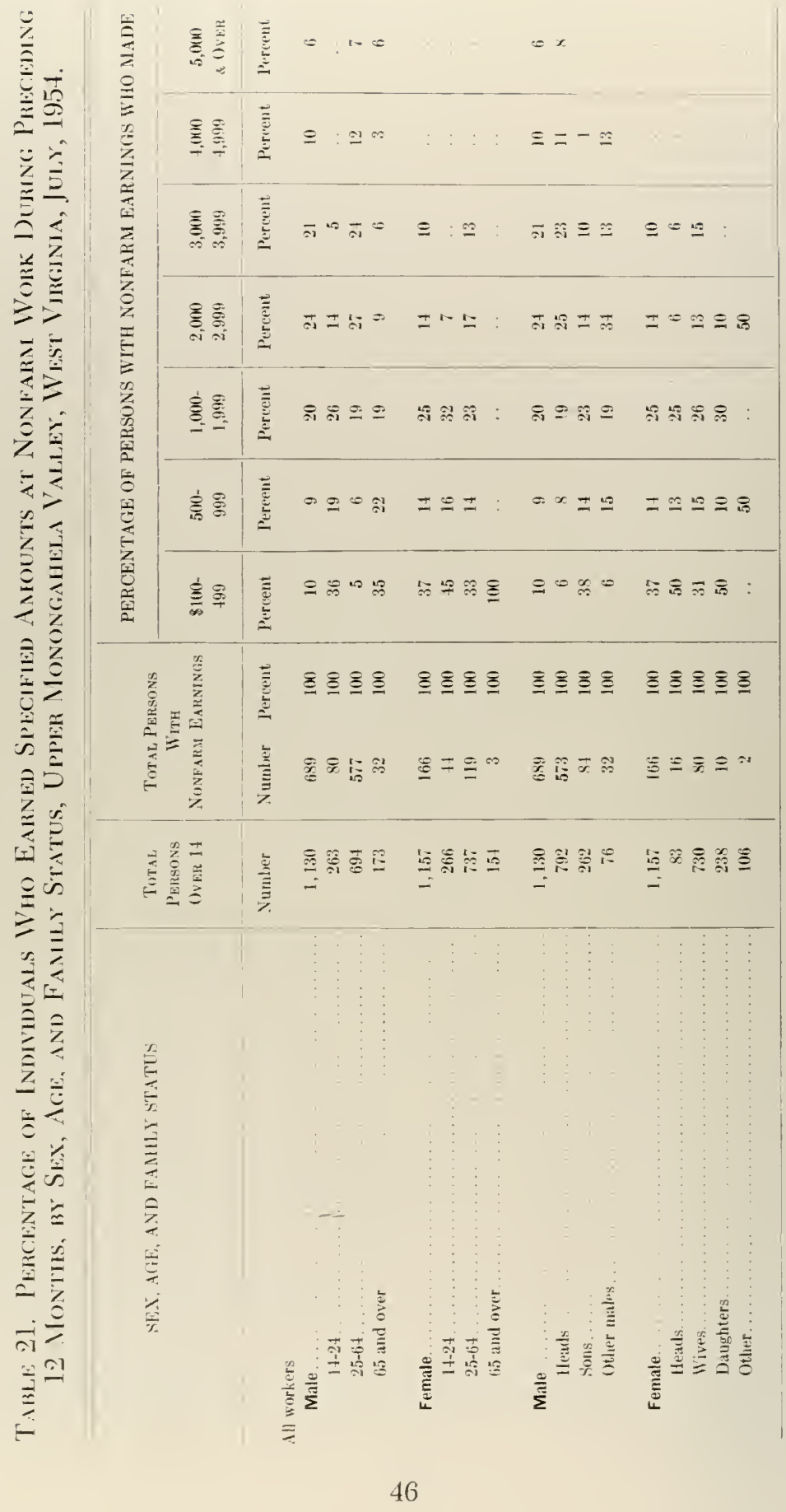


It had been anticipated that the study would show that the number engaged in nonfarm employment would (1) gradually increase from 1946 on as additional young people entered the labor force, and ( 2 ) var? noticeably with general economic and employment conditions in the area. In general these expectations were borne out. The number engaged in nonfarm work reached a peak in 19.53 when 8.55 people were engaged in this type of employment, an increase of almost one-fourth over 1946 (Table 22). Almost all of this increase occurred from 1946 to 1947 and from 19.52 to 1953. Presumably the gain in the years from 1946 to 1947 was associated with the return of servicemen to civilian employment after World War II, and the second gain with the industrial upswing that accompanied the Korean conflict.

Table 22. Number of Persons Who Exgagen m Nonfari Work. 1946-1954, by Sex, Household Status, and Residence, Upper Monongaiela Valley, West Virginia, July, 19.54.

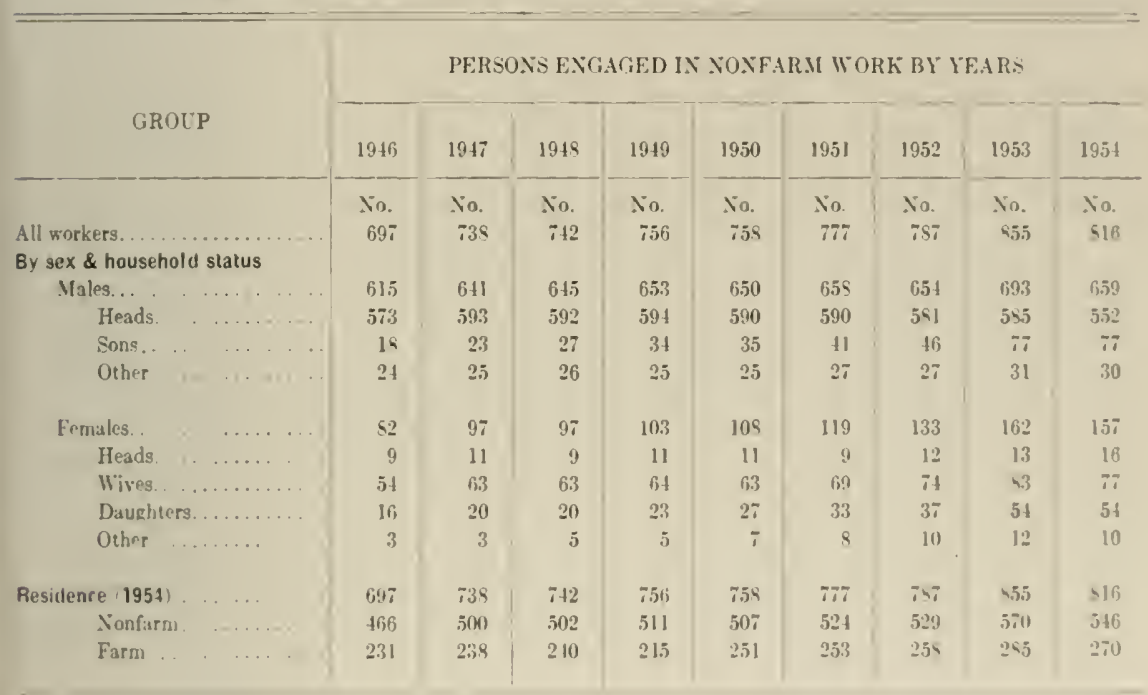

By 19.54 the mumber in nonfarm employment had dropped from 5.5.5 to s16. This decrease reflects the growing memployment in coal mining and other industries in the area.

When the employment records of these people are classified aceording to status in the houschold, we find that male heads of heossehends ordinarily have a fong record of nonfarm comploynent and of her members hate done nonfarm work for a much shorter period of time. The mumlure of male heads of homseholds who were employed at nemfarm work dul

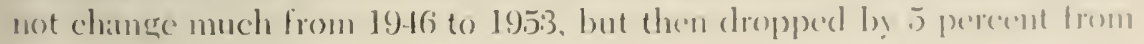


1953 to 1954 . By way of contrast, only 15 of the sons in the reporting households were employed at nonfarm work in 1946, whereas 77 were employed in both 1953 and 1954. The increase in employment of these people wàs rather gradual except for a very pronounced rise between 19.52 and 1953.

The number of wives who worked increased by about 50 percent during the 1946 to 1953 period and decreased about 5 percent from 19.53 to 1954 . These changes were almost entirely among wives from nonfarm households.

Only 15 daughters were employed in 1946, but there was a gradual increase in the ensuing years and a big upswing from 1952 to 1953 . By that time 54 were employed at some type of nonfarm work. The same number were employed in 1954.

Apparently 1953 afforded exceptional opportunities for young people to enter into employment. Then in 1954 when employment was cut back it was the older workers, both men and women, who were dropped.

The major nonfarm experience of one-fourth of these workers was in coal mining; for an equal proportion it was in sawmilling and miscellaneous types of manufacturing (Table 23). One of 6 workers had some experience in retail or wholesale business. Others had a background of work in transportation, public service, or skilled craftsmanship.

At the time of the survey, approximately one-third of the workers who had nonfarm experience were living on farms. The others had not

Table 23. Nonfarm Industry Worked in for the Longest Time, 1946-1954, by Household Status and Residence, Upper Monongahela Valley, West V'irginia, July, 1954.

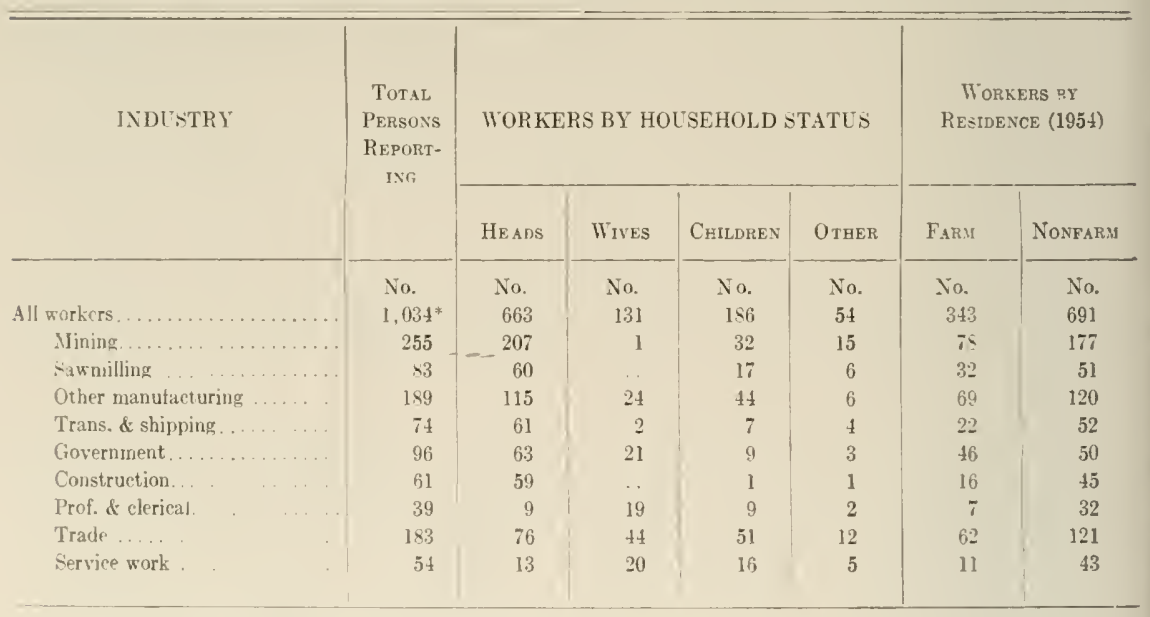

- 1.5 people omitted because of incomplete data. 
carried on sufficient agricultural production to be classified as living on farms. A higher proportion of govermment employees rated as farmers than those in any other occupational group.

\section{Youth Who Have Left Home}

When local employment opportunities are inadequate, many youncr people find it necessary to leave home in order to become self-supporting. Movement of young people from West Virginia to commercial and industrial centers in adjacent states has almost become traditional. An attempt to examine this was made by asking the persons contacted in the field survey to report on all persons who had left their households suring the previous $S$ years; that is, since the close of World War II. These reports were limited to members of the immediate family. as adecpuate information was generally lacking in regard to other persons.

Analysis of these reports was somewhat complicated by the varied situations typical of persons who leave home. On one hand are the young women who leave to get married and go into housekeeping for themselves. Then there are the sons who mary and leave home but who merely change their domicile and not their employment. A third typical group is made up of those who enter the armed forces. It is a fourth group that is of the greatest interest for this study; namely, those who leave home to find employment.

Members of two of these groups can be identified rather easily: Slightly more than half of the young women went into housekeeping when they left home and almost one-third of the young men went into the armed forces. Members of the other two groups are difficult to sep)arate, but since almost two-thirds of the young men went outside their home county, the number that went to new jobs eviclently was quite high.

Young men and young women were about exually numerous in the total of 401 persons who left churing the S-year period (Table 24). Movement was somewhat greater from farm than from nonfarm houscholels. One person had left from each 1.8 farm houscholds during this perioet as compared to 1 per 2.5 nonfarm households. This difference is on the hasis of farm or nonfarm residence only. It is further accentuated when the houscholds are elassified by their major seuree of income. The rate of departure from agricultural houseloolds, including both farm operation and farm labor, was 1 person per 1.5 hauseholds: mining. I person per 2.2 households; manufacturing, 1 person per 2.3 households: and other nonfarm, 1 person per 2.9 houscho!ds. Other types of houscholels, laregel those with nonwork incemes but including some that had incomes fiom a variety of sources, had a departure rate of I person per 2 houscholds. 


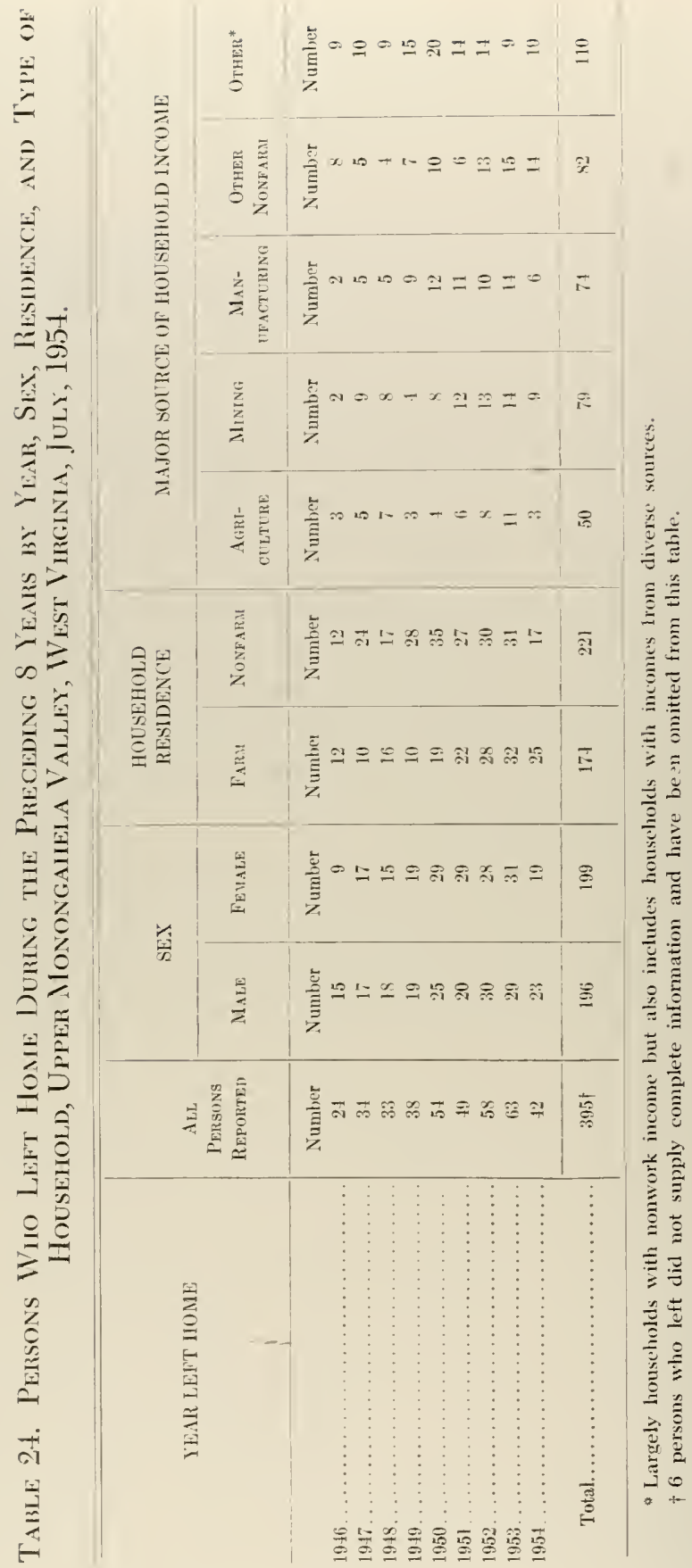




\section{MAJOR ACTIVITY BEFORE LEAVING, AFTER LEAVING, AND AT THE TIME OF THE SURVEY}

Although the departure rate was highest in farm households, very few of the youth had engaged in farm operation or hired farm work as their major activity before leaving home (Table 2.5). A large proportion had shifted over to nonfarm employment while still at home. Uore than half of the young men and almost one-third of the young women were doing some type of nonfarm work at the time they left. School attendance was their next most common activity. Almost half of the young women had been in school just before leaving (3.9 percent) as compared to one-fifth of the young men. Unpaid family work was also particularly common among the young women; 26 percent had been engaged in it or in keeping house as compared to $S$ percent of the young men. I higher percentage of the young men were reported as being unemployed.

Table 25. Major Acthity of Persons Who Left Hone Duming; th: Preceding $S$ Years, (1) Before Leavisg, (2) After Leavivg, aND

(3) At tue Presext Time, Upper Monongahela Valley, West Virgivia, July, 1954.

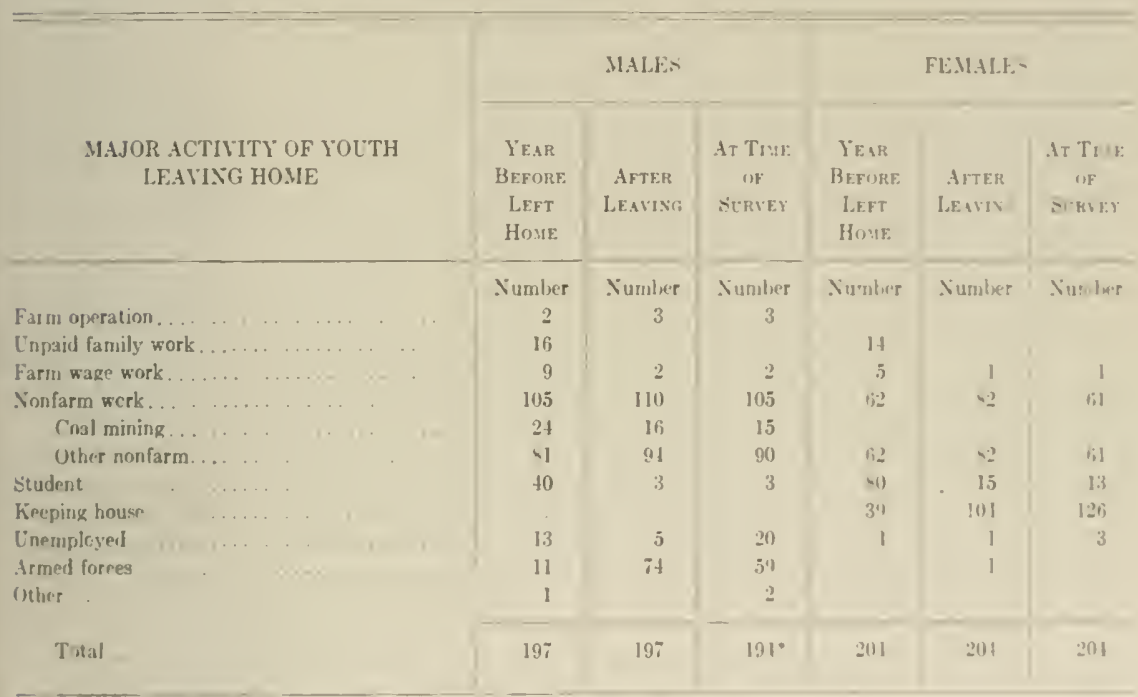

- 3 persous did not supply complete information.

A comparison of the major activity of these people before the' left home with that after they left and with that in which they were engiaged at the time of the survey indicates several major trends. Nore thin hall of the young women had left home to take up houscke'eping and an additional 10 percent had married after a few years of nonfarm empley ment Although 40 percent of the young women had been in mutarm emplus 
ment after leaving home, one-fourth of this group had quit their jobs and were keeping house at the time of the survey.

The employment shifts of the young men are obscured by the fact that more than one-third of them ( 38 percent) left to go into the armed forces and 30 percent of the total were in the military service at the time of the survey. Although 105 young men were in nonfam work before leaving home and 110 after leaving, as many as one-third of the original 10.5 may have gone to military service. If so, their places must have been taken by additional young men who left home to go into nonfarm employment.

Ten percent of the young men were reported as unemployed at the time of the survey. This evidences a real decline in economic opportunity, especially since only 6.5 percent were reported as unemployed during the time before they left home.

When the activities of the young people before leaving home were examined for differences on the basis of residence, the outstanding difference was in the proportion who had engaged in umpaid family work. Fifteen percent of the youth in farm households had unpaid work as their major activity during the year preceding the interviews, as compared to only 2 percent from the nonfarm households. (Table 26). The major activity of the young people, both in farm and nonfarm households, had been nonfarm work for 36 percent of those on farms and 47 percent of those in nonfarm homes. Thirty percent of those on farms and 29 percent of those in nonfarm households had been in school.

As might be expected, there was a significant shift of youth on farms to nonfarm employment. When allowance is made for the movement out of nonfarm work into the armed forces, the number of farm youth who went into nonfarm employment probably doubles. The number of nonfarm youth in nonfarm employment did not change. Hence, when allowance is made for those who went from nonfarm work into the armed forces, it appears that from one-third to one-fourth of the nonfarm youth entered nonfarm employment when they left home.

The households the young people left were also classified on the basis of chief source of total household income (Table 27). Nonfarm employment was common among youth in the agricultural households before they left home. Thirty-four percent had this type of employment as compared with 16 percent in farm-wage work and 2 percent in farm operation. A total of 40 percent of the youth from nonfarm work households engaged in nonfarm employment before leaving home; and 50 percent of those from nonwork and miscellaneous households did likewise. The major immediate shifts of the youth on leaving home were into nonfarm employment, into the armed forces, and into keeping house. 
Table 26. Major Activity of Persons Who Left Hove Dering the Preceding $S$ Years, (1) Before Leaving, (2) After Leaitic. and

(3) At the Time of the Surver, by Residexce of Holsenold,

Upper Monongahela Valley, West Virginia, Jely; 19.54.

\begin{tabular}{|c|c|c|c|c|c|c|}
\hline \multirow[b]{3}{*}{$\begin{array}{l}\text { MAJOR ACTIVITY OE YULTH } \\
\text { LEAVING HOME }\end{array}$} & \multicolumn{6}{|c|}{ HOL:SEHOLD RE.IDE.NCE } \\
\hline & \multicolumn{3}{|c|}{ FARS } & \multicolumn{3}{|c|}{ Novfa: } \\
\hline & $\begin{array}{c}\text { Year } \\
\text { BEFore } \\
\text { LeFt } \\
\text { Hes:se }\end{array}$ & $\begin{array}{l}\text { AHTER } \\
\text { LEAVING }\end{array}$ & $\begin{array}{l}\text { AT Tr:HF } \\
\quad \text { or } \\
\text { SHHVEY }\end{array}$ & $\begin{array}{l}\text { YEAR } \\
\text { BEFUR: } \\
\text { LEFT } \\
\text { Ho'IE }\end{array}$ & $\begin{array}{l}\text { AFTE } \\
\text { L.EA:TVI }\end{array}$ & 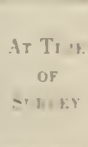 \\
\hline & Number & Number & Number & Nunsler & Xus ber & Nusule: \\
\hline $\begin{array}{l}\text { Farm operation. } \\
\text { Unpaid family work. . . . . . . . . . . . }\end{array}$ & $\begin{array}{r}2 \\
25\end{array}$ & 2 & 2 & 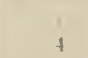 & 1 & 1 \\
\hline Farm wage work. . . . . . . . . . & 3 & 2 & 2 & 11 & 1 & 1 \\
\hline Nonfarm work $\ldots \ldots \ldots \ldots$ & 60 & 41 & 73 & 106 & 105 & $\because$ \\
\hline Coal mining ... & $i$ & 5 & $i$ & 17 & 11 & - \\
\hline Uther noufarm. & 53 & is & 69 & $* 9$ & 44 & -1 \\
\hline Student & 50 & 4 & fi & 61 & I11 & 111 \\
\hline Kepping house. . . & 14 & $\$ 1$ & 51 & 20 & fil & Ei: \\
\hline Inersployed & + & 2 & 4 & 13 & 4 & is \\
\hline Armed forces & 6 & 32 & 26 & 5 & +2 & 2 \\
\hline ()ther & $x^{2}$ & 1 & & 1 & & 2 \\
\hline TUTAL & 168 & 168 & 167 & 224 & $22 i$ & $2: 21$ \\
\hline
\end{tabular}

This was true whether the major source of income was from agriculture. mining, manufacturing, or other type of activity.

\section{METHOD OF FINDING OUT ABOUT FIRST JOB}

When any of these persons had left the houschold during the preceding 18 months, the respondents were asked how those that ledt had leamed about their first job away from home. In some eases, they had eleparted without having heard about a joh (Tahle. 29).

Information about a job was most commonly received from refativen or friencls. This type of contact was important for both youne men and yomg women and for those in all types of homseholds.

\section{VOCATIONAL TRAINING OF YOUTH WHO HAD LEFT HOME}

One-third of the young men and one-fourth of the voune woment

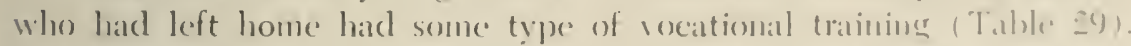

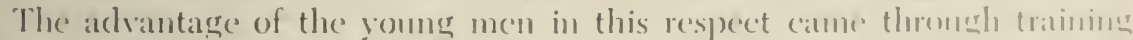
reecived in the armed forees and in (i. I. cliasses.

The most common type of training received he the vomes wement was in commercial courses in high school or in husimess collenes lmone 


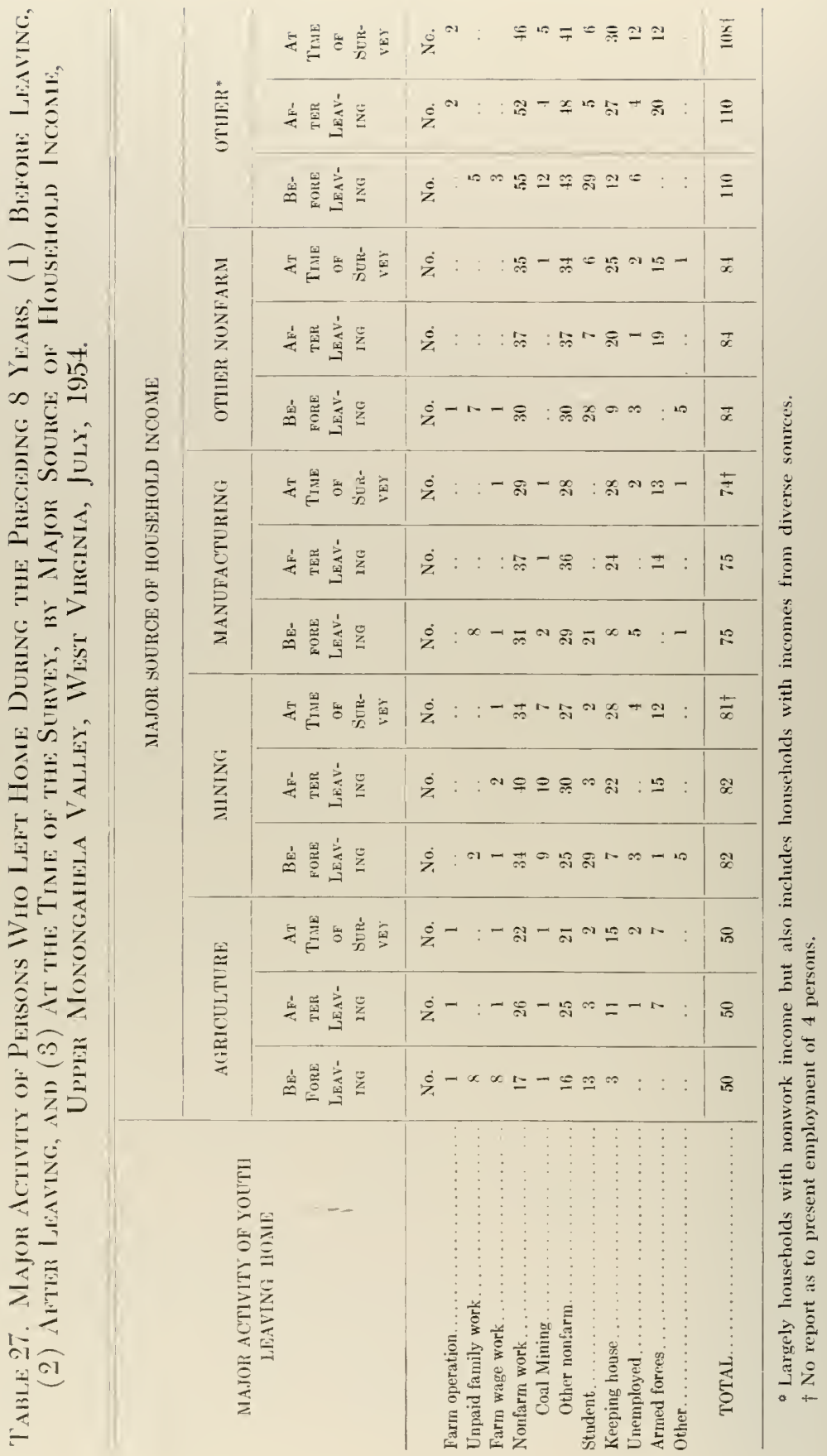


Table 28. Method of Finding Out About Job Away From Home, by Persons Who Left During 19.5.3 anid 19.54. by Sex, Restieice, a.dd Trpe of Holsemold, Upper Moxoygahela Valley; West Virginla, Juli, 19.54.

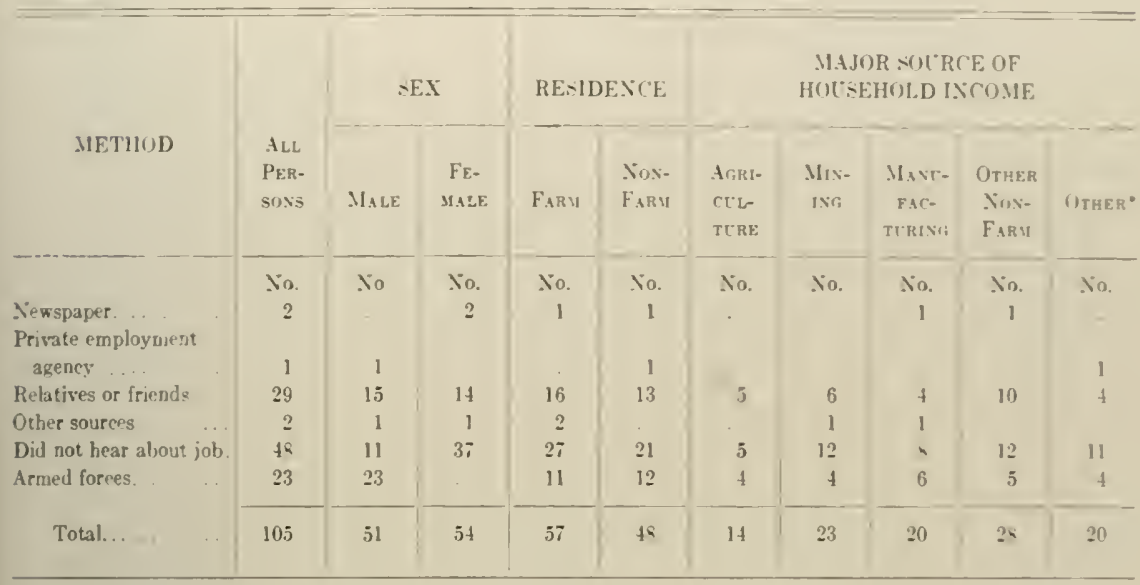

- Largely households with nonwork income but also includes households with incomen from diverse sourcts.

the young men, there was a major discrepancy between the type of training received and the type of vocation entered. Twenty-four persons had rocational agriculture courses, usually in high school, but only is had become farm operators and only 2 had become farm-wage workers.

\section{WHERE THEY ARE NOW}

Forty-one percent of the yomeng people clid not leave their home county (Table 30 ). The proportion remaining in the home county was especially high among young women ( 4.5 percent): anong people from nonfarm homes ( 47 percent); among youth from coal mining families ( 51 percent); and among youth from families with nomwork incones (49) percent). It was especially low among youth from manufacturing families (2S percent) and business, professional, and other nonfarm families (3.3 percent).

Some of the young people went to adjoining commties in Wrest V'irginia or to other parts of the State. This, howerer, wale less common than mosement to an adjoining staie or to some other part of the United States. Fouths from the homes of mamufacturing anployeres were partticularly prone to move to other states (IS pereent). Alunost 10 percent of the youth were reported as being outside the United Statten, but meart? all of these were in the armed services. 
Table 29. Vocational Training of Persons Who Left Hove Dering the Preceding $S$ Years, by Sex, Upper Moxongahela Yallex,

iVest Virginia, July, 1954.

\begin{tabular}{|c|c|c|c|}
\hline TYPE AND SOURCE OF TRAINING & $\begin{array}{c}\text { All } \\
\text { Persgis } \\
\text { With } \\
\text { TrainiNg }\end{array}$ & Mala & Female \\
\hline Type & Number & Nunber & Number \\
\hline Mechanical. & 14 & $1 t$ & \\
\hline Industrial . . & 6 & 5 & 1 \\
\hline Commercial & 42 & 0 & 33 \\
\hline Construction. & 5 & 5 & \\
\hline Handicraft. . & 3 & 3 & \\
\hline Agricultural & 24 & 24 & \\
\hline Teacher..... & $\&$ & 2 & 6 \\
\hline Other... & 12 & 4 & 8 \\
\hline Total. ............. & $114^{*}$ & 66 & 48 \\
\hline \multicolumn{4}{|l|}{ Source } \\
\hline High school. ... . . . . . . & ts & 24 & 24 \\
\hline Vocational or night schoal. & 6 & 3 & 3 \\
\hline Other school ............. & 20 & 7 & 13 \\
\hline Armed forces. & 17 & 17 & 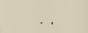 \\
\hline G. I. classes. & 14 & 11 & . \\
\hline On the job training. & 5 & 1 & 4 \\
\hline Other............. & 5 & . & 5 \\
\hline Total... & 115 & 66 & 49 \\
\hline
\end{tabular}

* No data on type of training for 1 youth who left.

\section{Work Away from Home}

Since local work opportunities were limited, unemployed people were lefi with a three-ivay choice:

First, to remain at home, help with the small amount of farm work or housework to be done, and wait for an opening to ocsur.

Second, to leave the area entirely and look for employment in areas where jobs were more plentiful.

Third, to seek employment in areas close enough to their present homes to permit them to return at rather frequent intervals. Actually, there was no distinct dividing line between workers who had left home completely and those who were still members of the household but living away from home. The questions in the interview were worded so as to permit the respondent to decide whether the person living away from home should be classified as still in the household or as having left it. Ordinarily, husbands away from home were more likely to still be 
Table 30. Where Persons Wilo Left Hoxe During the Preceding S Years Are Now Living, ey Sex, Residexce, axd Tripe of Hotsehold, Upper Moxoxgahela Valeey, West Virgivia, JULY, 19.54 .

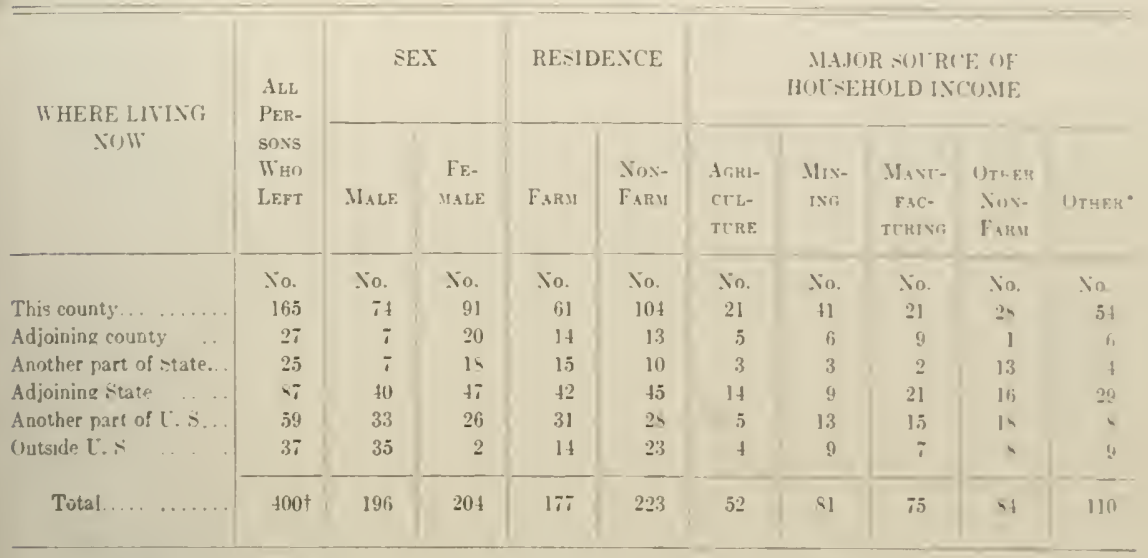

- Largely households with nonwork income but also includes howeholds with incomes trom various sources.

$\dagger$ Information about 1 person was not available.

regarcled as members of the household, whereas sons or claughters were regarded as having left.

Approximately one nonfarm worker in eight came in the gronp) regarded as still being in the household but living and working sonewhere else. These people usually worked in cities in Pemnsytuania or Ohio, but some were employed in Maryland, Virginia, or Washington. D. C.

Of 10:3 persons reported as members of the household but living away from home, more than half cither stayed away continumusly or retumed at rare intervals (Table 31). The others had jobs close enomgh that they could retum every week or two. Some of these people dicl at small amount of farming cluring their trips home. Workers in these groups ordinarily had been working away from home for onls a few months, but one-fourth of them had been away for about at ycar.

\section{Workers Who Had Returned Home}

The slackening of employment in West Virginia and ad liacent states in 19.5t resulted in unemployment not only for lecial perople lust also for some of the workers who had taken jols elsewhere. Vlans of the latter

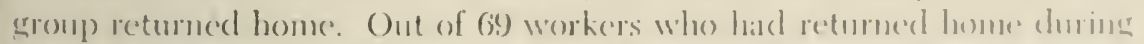

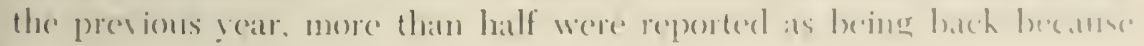


Table 31. Workers Who Had Lived Away Frox Hoxie During the Preceding 12 Months, by Sex, Household Status, and Continutty of Living Away, Upper Monongahela Valley, West Virginia, July, 1954.

\begin{tabular}{|c|c|c|c|c|c|c|}
\hline \multirow{3}{*}{$\begin{array}{l}\text { MONTHS LIVED } \\
\text { AWAY FROM HONE }\end{array}$} & \multirow{3}{*}{$\begin{array}{c}\text { All } \\
\text { Workers } \\
\text { Reporten }\end{array}$} & \multicolumn{3}{|c|}{ SEX AND HOUSEHOLD STATLS } & \multicolumn{2}{|c|}{ WORKERS LIVED AWAY } \\
\hline & & \multicolumn{2}{|c|}{ MALE } & \multirow{2}{*}{ FEM+LE } & \multirow{2}{*}{$\begin{array}{l}\text { Contint- } \\
\text { ously }\end{array}$} & \multirow{2}{*}{$\begin{array}{c}\text { Not } \\
\text { Contint- } \\
\text { OUSLY }\end{array}$} \\
\hline & & Heads & OTHERS & & & \\
\hline & Number & Number & Number & Number & Number & Number \\
\hline All workers. & 103 & 55 & 21 & 27 & 61 & 42 \\
\hline $1-3$ months. & 39 & 19 & 8 & 12 & 24 & 15 \\
\hline $4-6$ months. & 25 & 13 & 8 & 4 & 16 & 9 \\
\hline i- 9 months. & 14 & 7 & 2 & 5 & 12 & 2 \\
\hline 10-12 months. . & 25 & 16 & 3 & 6 & 9 & 16 \\
\hline
\end{tabular}

Table 32. Reasons Why Workers Returned to Upper Monongahela Valley, by Sex and Household Status, Upper Monongahela Valley, West Virginia, July, 1954.

All workers

Work gave out

Needed at home

sickness.

Did not like it away

Miscellaneous.

REASON FOR RETURNING

their work gave out (Table 32). Approximately 1 of 8 returned because they found that working, living, or other conditions away from home were unsatisfactory. A few returned because they were needed at home or because of sickness.

\section{Availability for Employment}

Each respondent was asked to indicate which members of the household were available for employment at the time of the interview. This

${ }^{33}$ For a more detailed discussion of people who were available for work, see Availability for Employment of Rural People in the Upper Monongahela Valley. W. Ta., by Ward F. Porter and William H. Metzler, West Virginia University Agr. Exp. Sta. Bull. 391, June, 1956. 
classification was to include both those who were actively looking for a job and those who were available for work but were not actively looking for a job at the time of the survey. A total of 351 persons. or 16 percent of those 14 years old and over, were reported as available for work. Approximately half of these were actively looking for work. (Table 33 ).

Table 33. Characteristics and Work Preference of People Who W'eize Avallable for Work, Uppen Moxongahela Valley, West VirciNia, JuLY, 1954 .

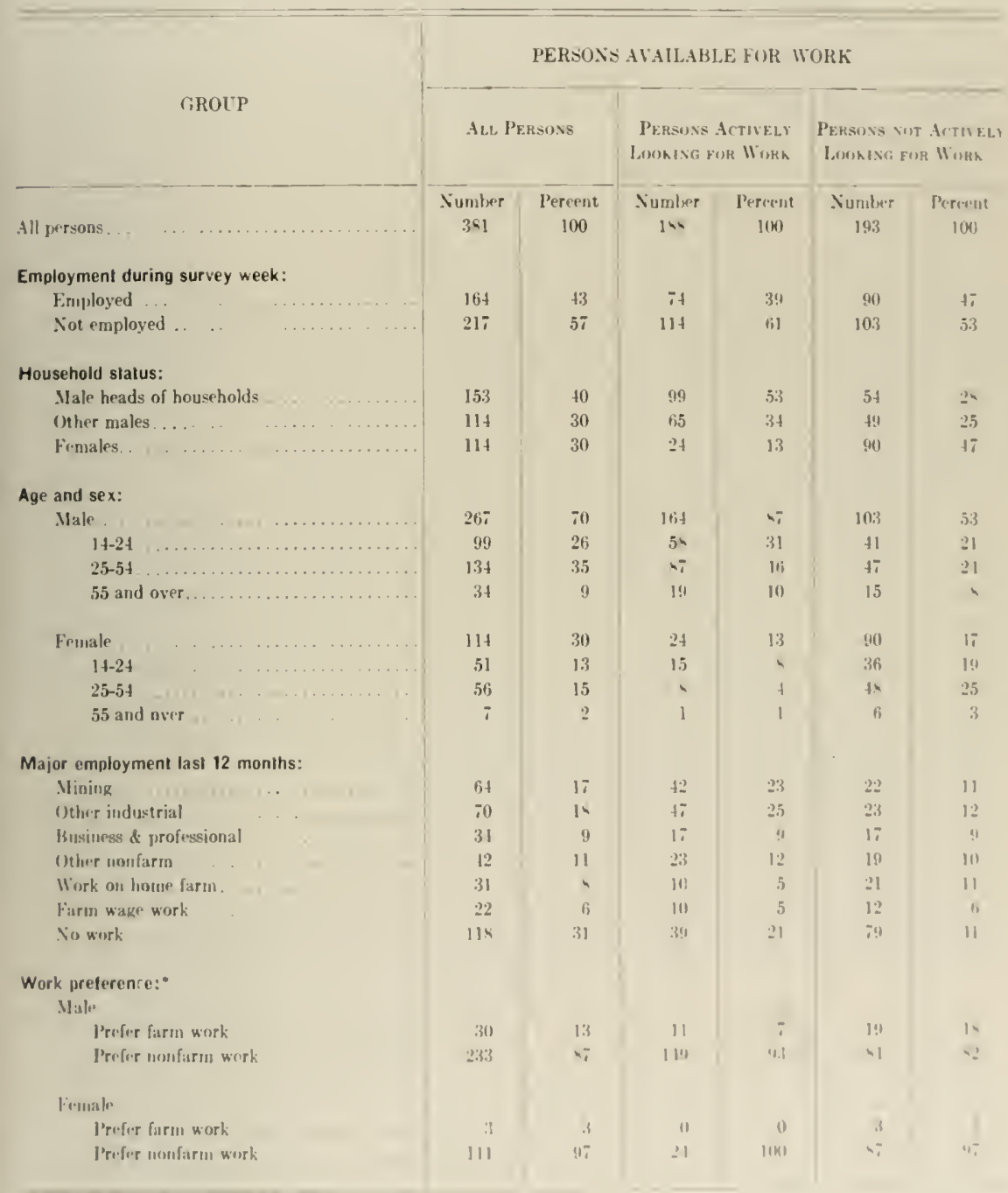

- Vis report as te work preferencere of 1 perums. 
A number of the people available for work had been employed for at least part of the time during the week of the survey. During the tight-job situation. many were taking unskilled or fill-in jobs until more suitable employment would be available. Forty-three percent of those available had some employment during the week preceding the interview. This involved slightly more than 40 percent of those actively looking and slightly less than 50 percent of the rest of the available group.

Approximately two-thirds of the available male workers were actively seeking employment as compared to about one-fifth of the women. As noted previously, the economy offers relatively few employment opportunities for women, and it is likely that this fact may have led many of them to be less active in seeking work. Those women who were actively looking were nearly all in the younger age groups; the less active included a large number of middle-aged women. The people actively looking for work ordinarily had been unemployed for some time. Nore than half of them had been seeking employment for 14 weeks or more; one-fifth had been looking for 6 months or longer (Table 34). Two-thirds of the male heads of households had been looking for 14 weeks or longer. In general, the older male heads had been looking for a longer time than those who were younger. Relatively few of the women had been looking for as long as 14 weeks.

\section{WORK PREFERENCE}

The people available for employment usually had a background of nonfarm work and were interested only in nonfarm employment. Ordinarily they looked on farm work as unskilled and underpaid and were not willing to consider the possibility of taking that type of employment. Only 33 of the 381 people available for work preferred a farm job; 3 of these were women; the rest were almost equally divided between household heads and other males. One-third of the people preferring farm work were youth or women who wanted part-time work.

A few of those who were looking for nonfarm work were primarily interested in part-time employment. This was true of one-third of the females but of only 10 percent of the male workers.

\section{UNEMPLOYMENT COMPENSATION}

Under the West Virginia-Compensation Law, insured workers are entitled to receive compensation when unemployed. Benefits are paid weekly for a 24-week period, the amount depending on the amount of contributions that had been made to the compensation fund.

Almost half of the persons looking for work had not applied for compensation. This included one-fourth of the male heads, two-thirds of the other males, and three-fourths of the females. Many of these people 
Table 34. Lexgth of Search for I'ork and Unemployalext Compfasation States of Persons Looking for Work, by Househol.d Statl's, Upper Moxoxgahela Valley, West V'irgiva, July, 19.54.

\begin{tabular}{|c|c|c|c|c|c|c|c|c|}
\hline \multirow{2}{*}{ [XEMPLOYMEXT EXPERIEXCE } & \multirow{2}{*}{\multicolumn{2}{|c|}{$\begin{array}{c}\text { All Persoxs } \\
\text { LuONixg } \\
\text { For Hork }\end{array}$}} & \multicolumn{6}{|c|}{-EX A YD HOL:EHULD STATL: } \\
\hline & & & \multicolumn{2}{|c|}{ MaLE HEans } & \multicolumn{2}{|c|}{ (1)THFH MaLES } & \multicolumn{2}{|c|}{ FE'ALES } \\
\hline All persons. ....... & $\begin{array}{c}\text { Number } \\
1 \text { taq }\end{array}$ & $\begin{array}{l}\text { Pereent } \\
100\end{array}$ & $\begin{array}{c}\text { Number } \\
99\end{array}$ & $\begin{array}{l}\text { Percent } \\
\qquad 100\end{array}$ & $\begin{array}{c}\text { Sumber } \\
65\end{array}$ & $\begin{array}{l}\text { l'ercoint } \\
\text { j(x) }\end{array}$ & Sumbir: & $\begin{array}{l}\text { Perpent } \\
\qquad I(x)\end{array}$ \\
\hline $0-13 \ldots \ldots \ldots \ldots \ldots$ & $\$ 6$ & 46 & 31 & 34 & 35 & 54 & 1: & $\because 1$ \\
\hline $14-26 \ldots \ldots \ldots \ldots \ldots \ldots \ldots \ldots \ldots$ & 65 & 34 & 41 & 12 & 23 & 3.5 & 1 & 4 \\
\hline $2 ;$ and over $\ldots \ldots \ldots \ldots \ldots \ldots$ & 37 & 20 & 24 & 24 & 7 & 11 & $b$ & 25 \\
\hline 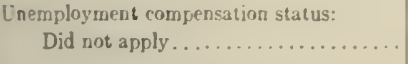 & 86 & 46 & 26 & 26 & 42 & 65 & Is & is \\
\hline Applied $\ldots \ldots \ldots \ldots \ldots \ldots \ldots$ & 102 & 54 & 73 & if & 23 & 35 & tj & 25 \\
\hline Received none ${ }^{*} \ldots \ldots \ldots \ldots$ & If & Is & 12 & 16 & 4 & 17 & 2 & \\
\hline -till drawing brnefits ....... & 59 & 57 & 43 & 59 & 13 & $5 i$ & 3 & \\
\hline $\begin{array}{l}\text { Vo lenger drawing, partial pay- } \\
\text { ment } \dagger \ldots \ldots \ldots \ldots \ldots \ldots \ldots\end{array}$ & $i$ & $i$ & 5 & $i$ & 1 & 4 & 1 & \\
\hline Full payment . . . . . . . & 15 & is & 13 & 18 & 5 & $2 \cdot 2$ & 0 & \\
\hline
\end{tabular}

\footnotetext{
- Either ineligible or application still being processced. rolls.

† Workers who received some compensation but are now employed so are off the compenadtom
}

were not eligible for compensation. Some had been working at jobs not covered by unemployment compensation; others were coming inte the labor market for the first time. Others were incligible because although they were looking for work, they were presently engaged in some type of remumerative employment.

About one-third of the persons who were looking for: work were drawing unemployment compensation at the tine of the interview. Another 10 percent had already exhausted all their monemployment benefits. About 4 pereent more had drawn some memployment paly but hatel obtained some type of employment before they had exhausted all their benefits. Apparently the work obtained had not been what they wimed and they were still looking for other jobs.

\section{WILLINGNESS TO LEAVE HOME}

The question was asked as to whether the perple an ailable for work were willing to leave home to take employment. In seneral. these whon watuted farm work were unwilling to go alsewhere. (Only is exprensed such a willinguess. On the other hatud, about two-thirch of theose interented in uonfarm work were willing to keate home (Tah)le. 3.5). This medueted 
Table 35. Potextial Mobility of Persons Avallable for axd Preferring Noxfarm Work, by Household Status and Age, Upper Moxongahela Vallex, West Virginia, July, 1954.

\begin{tabular}{|c|c|c|c|c|c|c|c|}
\hline \multirow{3}{*}{ 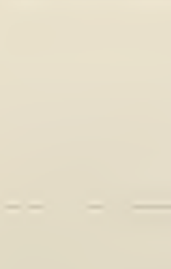 } & \multirow{3}{*}{ GROLP } & \multicolumn{3}{|c|}{$\begin{array}{c}\text { 1NDIVIDUAL } \\
\text { NONFARM WORK }\end{array}$} & \multicolumn{3}{|c|}{$\begin{array}{c}\text { FAMLLY HEADS PREFERRINC, } \\
\text { NONFARM WORK }\end{array}$} \\
\hline & & \multirow{2}{*}{ Total } & \multicolumn{2}{|c|}{$\begin{array}{l}\text { WiLLiva TO } \\
\text { LEATE HOYE }\end{array}$} & \multirow{2}{*}{ Total } & \multicolumn{2}{|c|}{$\begin{array}{l}\text { Willise to } \\
\text { Move Fav!IJY }\end{array}$} \\
\hline & & & Number & Percent & & Number & Percent \\
\hline All persons & & 344 & 219 & 64 & 136 & 101 & it \\
\hline \multicolumn{8}{|l|}{ Household status } \\
\hline Male heads & & 136 & 93 & 6s & 136 & 101 & it \\
\hline Other nales & & 97 & 81 & 84 & $\ldots$ & $\ldots$ & .. \\
\hline Females & & 111 & 45 & 41 & ... & $\ldots$ & \\
\hline \multicolumn{8}{|l|}{ Age } \\
\hline $14-31$ & , & 214 & 140 & 6.5 & 46 & 10 & 87 \\
\hline $35-54 \ldots \ldots$ & $\ldots \quad \ldots$ & 91 & 56 & 62 & $5 \varsigma$ & 42 & 72 \\
\hline 55 and over & & 39 & 23 & 59 & 32 & 19 & 59 \\
\hline
\end{tabular}

three-fourths of those who were actively looking for work. Sixty-nine percent of the household heads and $\$ 4$ percent of the other males were willing to go elsewhere. Less than half of the females were willing to leave. Young people were somewhat more willing to leave than those who were older.

The high percentage of persons who replied that they were willing to leave is surprising in view of the strong attachment many of them expressed for the area. This high rate of response may indicate several things: (1) pessimism about future employment opportunities in mining in the area; (2) an unwillingness to try farming even though it would permit them to stay in the Valley; (B) an unwillingness to accept lower incomes and a reduced level of living, or, on the other hand, (4) that replies under survey conditions, when there is no necessity to follow them up, may overstate willingness to go.

\section{WILLINGNESS TO MOVE FAMILY}

Household heads who preferred nonfarm work were asked whether they would be willing to move their families in order to take employment. Three-fourths replied that they would. The younger family heads were much more willing to move than those who were older.

\section{Employment of Persons Available for Work}

The 12-month employment record of the people available for work was highly variable. About one-third had done no work. At the other 
extreme almost one-fourth had worked for 300 days or more. apparentlyat jobs that were underpaid or were not to their liking. The figures are as follows:

\section{Days employed}

No days

1- 99

100-199

200-299

300 and over

Total
Number of workers

115

72

59

39

9:3

351

The available persons who had done no work during the previous year were largely women or youth. Of the $11 \mathrm{~s}$ persons in this group, 69 were under 25 years of age; 70 were women. Nany of these apparently: were looking for their first jobs.

The surprising fact about these people, however, is the large proportion who were steadily employed cluring the year. This probably was associated with several factors: first, the inability of a worker to choose his line of work in a labor market where jols were scarce; and second. the preference of these people to remain in their home area as lone as. it was economically possible.

Fonr-fifths of the 263 people who had worked during the previous 12 months had been employed at nonfarm work. This includes some who had also done some farm work. The majority of these people had worked either in mining or in other industrial employment, usually at nom-shillecl labor. Most of those who had done fam work were mupaid family workers but some had been farm operatons and others had been hired farm workers.

Twenty pereent of those who had worked during the presiom year had worked ontside the area. These people were generally willing to lave home again to secure employment.

\section{Comparison with Other Surveys}

Precise comparison of availability for employment of workers in Wrest Virginia with that of workers corered in the eastorn kentuchs and southeastem Oklahoma surveys is not possible because of dillerent methods of enumeration and classifieation. ${ }^{31}$ This applies particularly to the percentage of the workers who might be regiudeci ats alsibiable for :unployment. I fow ereneral statements, howerer, can be made. Althemesh

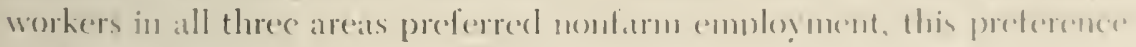

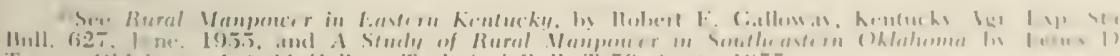

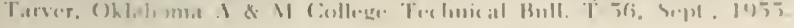


was greatest in West Virginia, probably because a higher proportion of the workers there already were in nonfarm lines of work. Opportunities in agriculture may also be somewhat more limited. Very few workers in any of the areas were willing to leave to take farm jobs, but from onethird to three-fourths were willing to leave to do nonfarm work. People on farms were much less ready to do so than those who were already in non-agricultural employment. Hence the percentage of workers willing to leave was much higher in West Virginia than in the other two states.

\section{Conclusion}

The Upper Monongahela Valley is representative of areas in which farm people have left agriculture for more profitable employment in a developing local industry. In this case, however, the local industry, coal mining, no longer needs the services of many of the workers who came to depend on it. The workers have come to depreciate farming as a source of livelihood and do not want to return to it. They prefer to remain in the Valley, but most of them state that they are willing to go elsewhere to do nonfarm work. A return to agriculture offers no solution since farming opportunities open to them would vield a very small return in comparison to the incomes to which these people have become accustomed. Any solution must be along the line of new industries in the area or an outmigration of workers to expanding industrial areas.

The few people who still remain in agriculture in the area are much less fully employed than those who have gone into industrial employment. The small farm incomes suggest that farm units are too small and that there is a lack of capital needed to produce on the most efficient basis. More nonfarm employment opportunities are needed for these people.

Live-at-home farming, even though inefficient, does constitute a valuable supplement to the incomes of many of the nonfarm workers. A subsequent report will indicate whether the efficiency of these units can be improved so as to provide more of a supplement to nonfarm workers who are seasonally inemployed.

Eighty percent of the workers have had several years of industrial or business experience, which constitutes a valuable resource in itself. They have become adjusted to-regular employment and have accuired skills that are valuable for nonfarm occupations. To overcome the underemployment of farm people who have not had such nonfarm experience probably will be a larger and more difficult job than the occupational readjustment of nonfarm workers.

The development of local industries, or bringing in new ones, is much to be preferred to outmigration of the underemployed workers. 
The latter means reduced home markets, reduced number of workers in relation to the number of dependents, and disruption of established home and community relationships.

Local leaders might do well to canvass the potentialities for new industries in the area. The varied local natural resources plus a reserve of manpower should furnish a basis for several lines of industrial development. Casual observation, for example, indicates excellent resources for the development of recreational activities." Tr: Tusportation, comparative costs of production, market outlets, and similar factors will have to be weighed so as to guard against the introduction of industries which could not compete successfully with those in other areas. Special attention needs to be given to the effects of atomic-power development which may bring new shifts in industrial advantages.

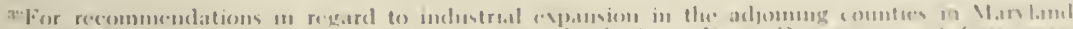

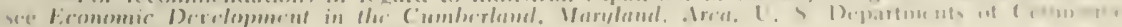
and Liabor, Wishingtum. I), C., Oifoluer, 19.5.2. 



\section{APPENDIX}

A sample was desired which would provide an accurate cross-section of the households, farm and nonfarm, in the open-country area of the Valley. Sampling on a geographic basis presented something of a problem because some areas of the Valley were sparsely settled, whereas others were densely populated in spite of the rugged terrain. Furthermore. there had been numerous population shifts since the 19.50 Census which provided the most recent guide as to local densities of population.

Sampling specialists at the U. S. Department of Agriculture were asked to draw a sample that would yield from 800 to 1,000 operi-country respondents. Sampling for this survey was done on a segmented-or local-area basis. A total of 86 sample segments were drawn. with each estimated to contain about 10 households. These segments covered the 10-county area in proportion to the estimated open-country population.

In drawing the sample, allowance was made for shifts in the opencountry population from 1950 to the date of the survey. Allowance was also made for the expansion of urban areas.

This method provided a randomized hasis for selection of households and yielded 914 households. Interviews were taken from SSS households, or 97 percent of the total households in the survey area sample group. During the analysis a few of the schedules were discarcled for technical reasons.

\section{Classifications and Terminology}

In general, the classifications and terminology used in this report follow those that have been used by the Census and other statistical agencies. In a few cases, special classifications, or terms, were worked out in order to meet the particular needs of this survey.

The classifications used are as follows:

Rural

Open country

Farm

\section{Commercial farm}

living in the open country or in settlements of less than 2,500 people. (Censiss.) areas with no settlement of more than Io() people.

(1) places of 3 or more acress on which value of agricultural products. exclusive of home gitrelems. amounted to $\$ 1.50$ (or more; and

(2) places of less than 3 acrees on which the siles on farm products amounted to $\$+5)$ or more. ( Comsus.)

(1) all farms with sales of firm products atmomuting to $\$ 1,2(0)$ or more; (2) farms with sales of from 5.2 .71 to $\$ I, 199)$ on which the operater worked off the tarm for less than $f(0)$ dists and the nentarm incomene of all 
members of the family was less than the total value of farm products sold. (Census.)

Part-time farm farms with sales of farm products of from $\$ 250$ to $\$ 1,199$ when either (1) the farm operator worked 100 days or more off the farm or (2) the nonfarm income of all members of the family was greater than the value of farm products sold. (Census.)

Residential farm farms with sales of less than \$2.50. (Census.)

Labor force

all persons 14 years old or over who are either (1) employed; (2) unemployed; or (3) members of the armed forces. (Census.)

Nonwork income income other than earnings; e.g., from rents, royalties, interest, dividends, veterans allotments, social security, unemployment insurance, public assistance.

Household all the persons who occupy a home or dwelling unit. (Census.)

Underemployment underutilization of a worker's time and ability either through (1) employment for less than a full working year; or (2) employment at work which does not make full use of his training and ability.

Level of living measured in this survey by the possession of 10 selected items-electric lights, rumning water, telephone, daily newspaper, refrigerator, power washing machine, automobile or truck, flush toilet, kitchen sink, (leep-freeze unit.

Chief income source of households as between farm operation, farm wage work, mining, manufacturing, business or professional, other nonfarm work, and nonwork sources.

Income type of households as between farm, nonfarm work, and nonwork sources.

Major activity

the activity at which an individual spent the greatest amount of his time during the 12 months preceding the interview. Adapted from the Census.

\section{Industrial-}

occupational

classification

adapted from Ceusus to fit industries in the area. These are:

Agriculture, including farm operators, farm wage workers, unpaid family workers.

Mining, including managers, operatives and unskilled workers in coal mines.

Sawmilling, including owners, managers, laborers.

Other manu-

facturing, including operators and workers. 
Transporta-

tion and

shipping.

includes railroad workers, truck drivers, cab drivers.

Govermment, includes local, State, and Federal workers; e.g., teachers, school bus drivers, mailmen, policemen, sheriff, and clerical workers in Government offices.

Construction, includes carpenters, painters, plumbers, bricklayers, electricians.

\section{Professional}

and

clerical, includes doctors, nurses, lawyers, engineers, stenographers, bookkeepers, typists.

Trade, includes operators, managers, salesclerks, and laborers.

Service work, includes housework, janitor, cook, watchman, barber. odd-jobs workers. 
